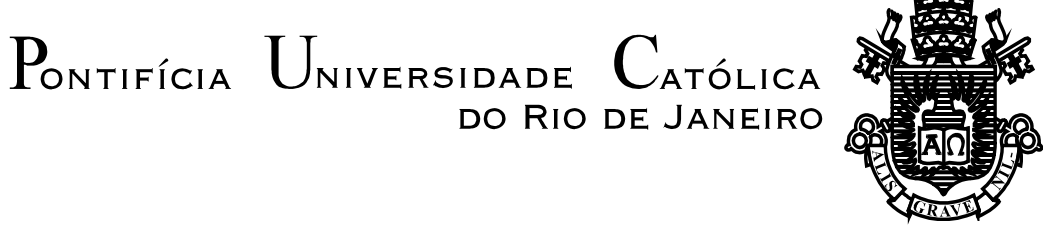

Geizi Fernandes de Souza

\author{
O Letramento Financeiro e a Matemática \\ Financeira Básica no Ensino Fundamental
}

Dissertação de Mestrado

Dissertação apresentada ao Programa de Pós-graduação em Matemática da PUC-Rio como requisito parcial para obtenção do título de Mestre em Matemática (opção profissional).

Orientadora: Profa. Renata Martins da Rosa

Rio de Janeiro

Julho de 2016 


$$
\text { Pontifícia Universidade } \text { Católica }_{\text {Do Rio de Janeiro }}
$$

Geizi Fernandes de Souza

\section{O Letramento Financeiro e a Matemática Financeira Básica no Ensino Fundamental}

Dissertação apresentada como requisito parcial para obtenção do grau de Mestre pelo Programa de PósGraduação em Matemática do Departamento de Matemática do Centro Técnico Científico da PUC-Rio Aprovada pela Comissão Examinadora abaixo assinada.

Profa. Renata Martins da Rosa

Orientadora

Departamento de Matemática - PUC-Rio

Profa. Christine Sertã Costa

Departamento de Matemática - PUC-Rio

Profa. Liliana Manuela Gaspar Cerveira da Costa Colégio Pedro II

Profa. Emília Carolina Santana Teixeira Alves Departamento de Matemática - PUC-Rio

Prof. Márcio da Silveira Carvalho Coordenador Setorial do Centro Técnico Científico - PUC-Rio

Rio de Janeiro, 28 de julho de 2016 
Todos os direitos reservados. É proibida a reprodução total ou parcial do trabalho sem autorização da universidade, da autora e da orientadora.

\section{Geizi Fernandes de Souza}

Graduou-se em Licenciatura em Matemática na Universidade do Estado do Rio de Janeiro - Uerj em 1999. Cursou o Aperfeiçoamento para Professores de Matemática do Ensino Médio, pelo Instituto de Matemática Pura e Aplicada - Impa. Especializou-se em Matemática pela Faculdade Internacional Signorelli em 2014. Atualmente é analista na Financiadora de Estudos e Projetos - Finep e professora efetiva de Ensino Fundamental na Secretaria Municipal de Educação de Duque de Caxias.

Ficha Catalográfica

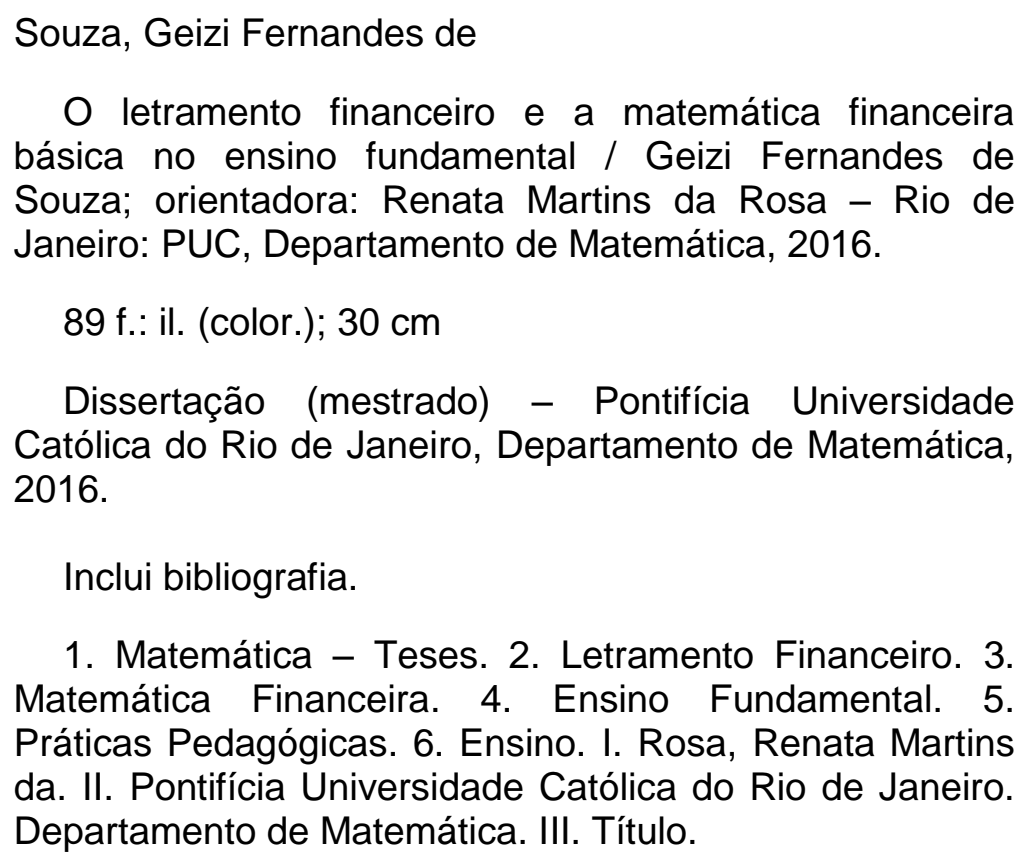

Inclui bibliografia.

1. Matemática - Teses. 2. Letramento Financeiro. 3. Matemática Financeira. 4. Ensino Fundamental. 5. Práticas Pedagógicas. 6. Ensino. I. Rosa, Renata Martins da. II. Pontifícia Universidade Católica do Rio de Janeiro. Departamento de Matemática. III. Título. 
Dedico esta dissertação aos meus pais, Osny Silva Souza e Jeni Fernandes de Souza, meus maiores incentivadores durante toda a vida. 


\section{Agradecimentos}

Acima de tudo, a Deus, por me conceder saúde, serenidade e força para a realização deste trabalho.

Aos meus pais, que sempre acreditaram em mim e envidaram todos os esforços para a minha educação, dentro dos seus limites e possibilidades.

Ao meu filho, Gabriel Fernandes da Cunha, por compreender minhas ausências nos momentos de estudo.

Ao meu amor, amigo e companheiro, Helio Furtado Costa, com quem pude contar durante a confecção deste trabalho e em sua revisão. Seu apoio foi imprescindível para a realização e finalização deste trabalho.

À PUC-Rio, pela bolsa de isenção que permitiu os meus estudos numa universidade de excelência.

À minha orientadora, Prof. ${ }^{a}$ Renata Martins da Rosa, pela paciência, compreensão e sugestões valiosas durante essa jornada.

Aos meus professores e colegas da turma de 2014 do mestrado PROFMAT da PUC-Rio, que contribuíram significativamente para o aprimoramento da minha formação. 


\section{Resumo}

Souza, Geizi Fernandes de; Rosa, Renata Martins da (Orientadora). O letramento financeiro e a matemática financeira básica no Ensino Fundamental. Rio de Janeiro, 2016. 89p. Dissertação de Mestrado Departamento de Matemática, Pontifícia Universidade Católica do Rio de Janeiro.

O letramento financeiro do indivíduo é condição fundamental para seu planejamento financeiro e para a tomada de decisões financeiras conscientes. $\mathrm{O}$ conhecimento de Matemática Financeira é uma das plataformas necessárias ao letramento financeiro. Nesse sentido, consideramos que o ensino de Matemática Financeira deve ser iniciado o mais cedo possível, de forma contextualizada e adequada à faixa etária do educando. Neste trabalho apresentaremos propostas pedagógicas e metodológicas para o efetivo ensino de Matemática Financeira Básica no segundo segmento do Ensino Fundamental, baseadas em nossa experiência de trabalho nesta etapa, há mais de dez anos.

\section{Palavras-chave}

Letramento Financeiro; Matemática Financeira; Ensino Fundamental; Práticas Pedagógicas; Ensino. 


\section{Abstract}

Souza, Geizi Fernandes de; Rosa, Renata Martins da (Advisor). Financial literacy and basic financial mathematics in middle school. Rio de Janeiro, 2016. 89p. MSc. Dissertation - Departamento de Matemática, Pontifícia Universidade Católica do Rio de Janeiro.

The person's financial literacy is a prerequisite for their financial planning and for making conscious financial decisions. The Financial Mathematics knowledge is one of the platforms necessary for financial literacy. In this sense, we consider that the Financial Mathematics teaching should be started as soon as possible, in context and appropriate to the student's age. In this work we present pedagogical and methodological proposals for effective teaching of basic knowledge of Financial Mathematics in Middle School, based on our experience working with this segment for more than ten years.

\section{Keywords}

Financial Literacy; Financial Mathematics; Middle School; Pedagogical Practices; Teaching. 


\section{Sumário}

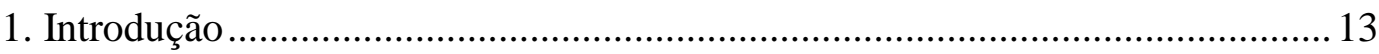

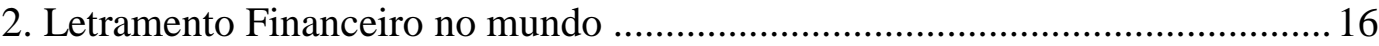

2.1. Letramento Financeiro nos Estados Unidos ................................................. 17

2.2. Pesquisa sobre Educação Financeira Global da S\&P (The S\&P Global

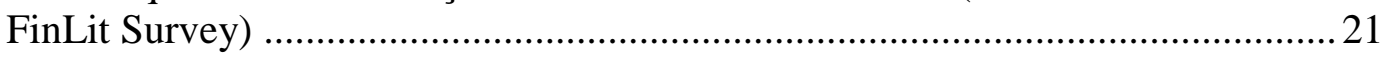

2.3. Letramento Financeiro e conhecimento matemático...................................... 30

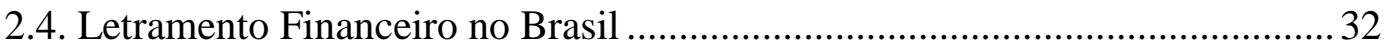

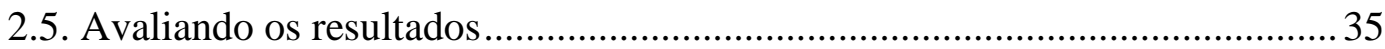

3. Estratégia Nacional de Educação Financeira - ENEF.......................................37

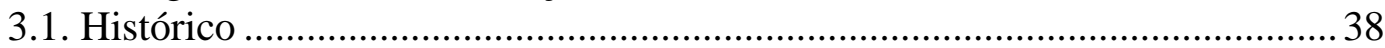

3.2. Comitê Nacional de Educação Financeira - CONEF...................................... 40

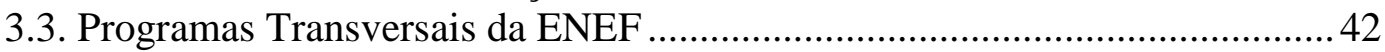

3.3.1. Programa de Educação Financeira de Adultos ............................................ 43

3.3.2. Programa Educação Financeira nas Escolas............................................... 44

3.4. Mapeamento Nacional de Iniciativas de Educação Financeira ....................... 46

3.5. Base Nacional Comum Curricular................................................................ 47

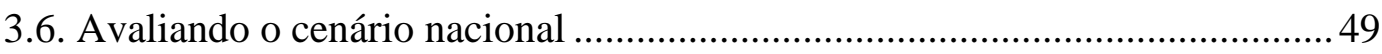

4. Matemática Financeira no Ensino Fundamental .............................................5 50

4.1. A importância da contextualização................................................................51

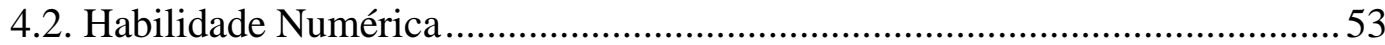

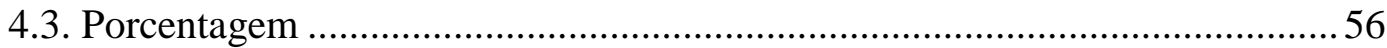

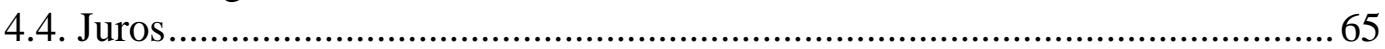

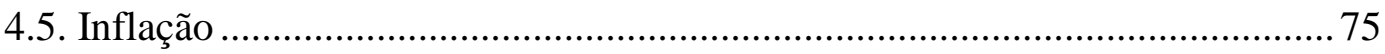

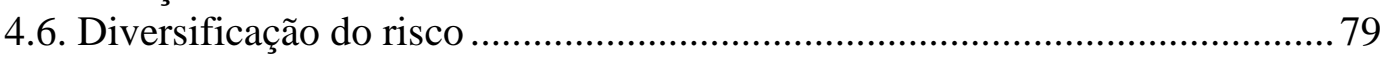

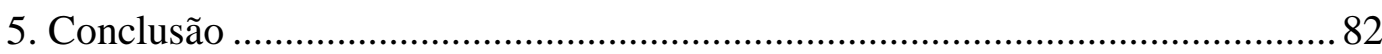

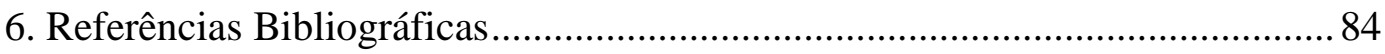

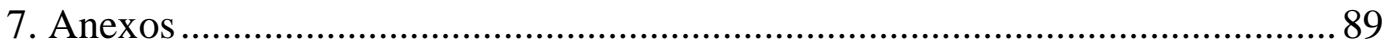

7.1. Anexo A - Questionário de diversificação do risco ..................................... 89 


\section{Lista de figuras}

Figura 1 - Aumento da expectativa de vida no mundo....................................... 16

Figura 2 - Percentual de adultos letrados financeiramente no mundo .................. 24

Figura 3 - Letramento financeiro nos países desenvolvidos e nos países

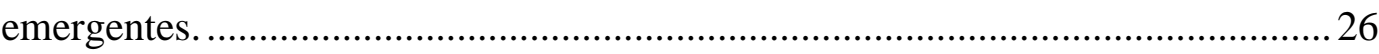

Figura 4 - Letramento financeiro entre os gêneros: percentual de adultos letrados financeiramente (com respostas corretas para pelo menos três de quatro conceitos) ou "não sei".

Figura 5 - Letramento financeiro e desigualdade de renda: percentual de adultos que são letrados financeiramente entre os $60 \%$ mais ricos e os $40 \%$

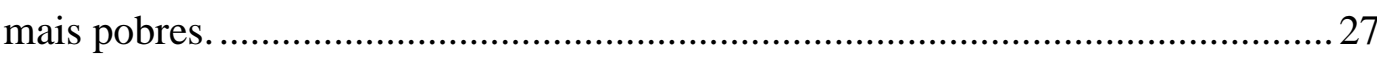

Figura 6 - Relação entre letramento financeiro e PIB per capita. ........................ 28

Figura 7 - Letramento financeiro por faixa etária............................................. 28

Figura 8 - Percentual de adultos com letramento financeiro por conceito. .......... 29

Figura 9 - Letramento financeiro de usuários de contas bancárias...................... 30

Figura 10 - Comparativo entre os resultados do exame de matemática do PISA 2012 e os resultados da Pesquisa Global. ................................................. 31

Figura 11 - Letramento financeiro no Brasil: percentual de acertos as

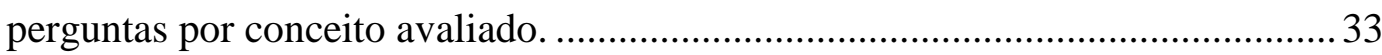

Figura 12 - Letramento financeiro entre os gêneros no Brasil.............................. 33

Figura 13 - Letramento financeiro por faixa etária no Brasil. ............................. 34

Figura 14 - Letramento financeiro e desigualdade de renda no Brasil..................35

Figura 15 - Dimensões da Educação Financeira................................................. 40

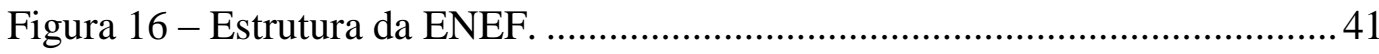

Figura 17 - Coleção de livros do Programa de Educação Financeira nas

Escolas: Ensino Médio.

Figura 18 - Livros do professor e do aluno para o $8^{\circ}$ e $9^{\circ}$ anos de escolaridade do Programa de Educação Financeira nas Escolas: Ensino Fundamental.............. 46

Figura 19 - Gráfico comparativo entre um capital aplicado com juros simples

e juros compostos.

Figura 20 - Gráfico representativo da preferência dos alunos em realizar uma única prova bimestral ou três provas bimestrais para se efetuar a média.

Figura 21 - Gráfico representativo da preferência dos alunos em realizar uma prova com uma única questão que vale 10 pontos ou cinco questões, com cada qual valendo 2 pontos. 


\section{Lista de tabelas}

Tabela 1 - Letramento financeiro nos Estados Unidos ....................................... 20

Tabela 2 - Adultos com letramento financeiro em economias selecionadas ........ 25

Tabela 3 - Estimativa do desconto da dívida estadual pela aplicação da Selic

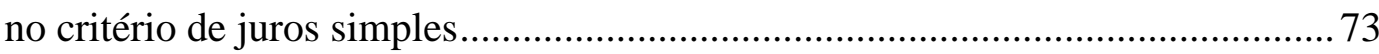




\section{Lista de quadros}

Quadro 1 - Resolução de questão de porcentagem por regra de três simples.......58

Quadro 2 - Questão do Exame Nacional do Ensino Médio (2015) ......................59

Quadro 3 - Questão do Exame Nacional do Ensino Médio (2014) ....................... 60

Quadro 4 - Resolução de questão do Enem 2014 ................................................. 61

Quadro 5 - Questão envolvendo acréscimo e desconto sucessivo .........................63

Quadro 6 - Resolução da questão envolvendo acréscimo e desconto sucessivo .. 64

Quadro 7 - Questão introdutória de juros simples retirada de livro didático.........66 66

Quadro 8 - Questão envolvendo juros compostos e simples ................................69

Quadro 9 - Questão envolvendo taxa de juros ..................................................... 70

Quadro 10 - Questão envolvendo a ideia de inflação .......................................... 77 


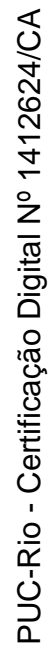

A educação é a arma mais poderosa que você pode usar para mudar o mundo.

Nelson Mandela 


\section{Introdução}

Desde o início do curso de Mestrado Profissional em Matemática em Rede Nacional na PUC-Rio - PROFMAT ${ }^{1}$, apresentávamos interesse em desenvolver uma dissertação que abordasse um tema relacionado ao ensino de Matemática Financeira na Educação Básica.

Ao consultarmos, em maio de 2016, a lista das dissertações de mestrado dos alunos do PROFMAT que tinham abordado esse tema, encontramos mais de 80 dissertações sobre Matemática Financeira entre as mais de 2.400 já defendidas. Entretanto, verificamos que a maioria dos títulos abordava pesquisas sobre o trabalho com Matemática Financeira no Ensino Médio. Além disso, dentre aqueles que propunham pesquisas relacionadas à Educação Básica, a maioria das propostas pedagógicas apresentadas tinham foco no trabalho com o Ensino Médio, frequentemente associado ao ensino de progressões geométricas.

Concordamos que o estudo das progressões geométricas é um indutor natural para a abordagem dos juros compostos e outros temas relacionados à Matemática Financeira no Ensino Médio. Porém, acreditamos que o estudo de Matemática Financeira, como uma das plataformas necessárias à educação financeira do indivíduo, deve ser iniciado o mais cedo possível, adequado à maturidade e à capacidade de entendimento no respectivo nível de ensino.

Dessa forma, considerando nossa experiência em lecionar em salas de aula de $6^{\circ}$ ao $9^{\circ}$ ano de escolaridade há mais de dez anos, decidimos realizar uma pesquisa voltada exclusivamente ao professor desse segmento de ensino, o qual geralmente não possui no livro didático um material de apoio suficiente para a abordagem desse tema. A nossa prática demonstra que é possível iniciar a

\footnotetext{
1 O PROFMAT - Mestrado Profissional em Matemática em Rede Nacional é um curso semipresencial, com oferta nacional, realizado por uma rede de Instituições de Ensino Superior, no contexto da Universidade Aberta do Brasil, e coordenado pela Sociedade Brasileira de Matemática. O PROFMAT visa a atender professores de Matemática em exercício no ensino básico, especialmente na escola pública, que busquem aprimoramento em sua formação profissional, com ênfase no domínio aprofundado de conteúdo matemático relevante para sua atuação docente.
} 
discussão de problemas de Matemática Financeira (e educação financeira) no Ensino Fundamental.

O presente trabalho é composto de sete capítulos, sendo o primeiro esta introdução.

No segundo capítulo, apresentaremos os resultados de uma pesquisa sobre o nível de letramento financeiro da população estadunidense, realizada pelas professoras Annamaria Lusardi ${ }^{2}$ e Olivia Mitchell. Nesse capítulo, exibiremos ainda os dados de um trabalho sobre o letramento financeiro ao redor do mundo, que também conta com a participação de Lusardi, o qual apresenta resultados e conclusões sobre uma pesquisa mundial sobre letramento financeiro.

Avaliamos que a abrangência e os resultados da referida pesquisa mundial são relevantes para a sensibilização do leitor quanto ao problema que enfrentamos: carência global de letramento financeiro, agravada no Brasil.

Considerando que Lusardi é uma autoridade na área de letramento financeiro e sua produção bibliográfica está disponibilizada em língua inglesa, julgamos que a apresentação detalhada da aludida pesquisa em um trabalho em língua portuguesa pode tornar seus resultados acessíveis a professores de todo o Brasil.

Além disso, tivemos a oportunidade de assistir uma palestra de Lusardi no "Seminário de Educação Financeira para Crianças e Jovens", organizado pela Comissão de Valores Mobiliários $-\mathrm{CVM}^{3}$ e pela Bolsa de Valores, Mercadorias e Futuros de São Paulo - BM\&FBovespa ${ }^{4}$, na qual a professora apresentou os resultados da pesquisa mundial específicos do Brasil e que não estão disponíveis nos documentos publicados.

\footnotetext{
${ }^{2}$ Annamaria Lusardi é uma das maiores autoridades mundiais em educação financeira e letramento financeiro. Já recebeu muitos prêmios por suas pesquisas, entre os quais o Fidelity Pyramid Prize, voltado para os autores de pesquisas aplicadas que mais ajudaram a melhorar o bem-estar financeiro dos americanos ao longo da vida. É Diretora Acadêmica do Centro de Excelência em Letramento Financeiro Global - GFLEC da Universidade George Washington, nos Estados Unidos.

${ }^{3}$ A Comissão de Valores Mobiliários - CVM foi criada em 07/12/1976 pela Lei 6.385/76, com o objetivo de fiscalizar, normatizar, disciplinar e desenvolver o mercado de valores mobiliários no Brasil.

${ }^{4}$ A BM\&FBOVESPA é uma companhia que administra mercados organizados de Títulos, Valores Mobiliários e Contratos Derivativos, além de prestar serviços de registro, compensação e liquidação, atuando, principalmente, como contraparte central garantidora da liquidação financeira das operações realizadas em seus ambientes. A Bolsa oferece ampla gama de produtos e serviços, tais como: negociação de Ações, Títulos de Renda Fixa, Câmbio Pronto e Contratos Derivativos referenciados em Ações, Ativos Financeiros, Índices, Taxas, Mercadorias, Moedas, entre outros.
} 
No terceiro capítulo, exibiremos uma síntese da Estratégia Nacional de Educação Financeira - $\mathrm{ENEF}^{5}$, o que julgamos interessante para demonstrar que o Brasil reconhece, ao menos na dimensão legal, a gravidade do problema, tendo sinalizado a intenção de adotar políticas públicas voltadas à melhoria da educação financeira de sua população. Entretanto, embora essa iniciativa já tenha alguns anos, ela ainda não é conhecida pela imensa maioria dos professores do Ensino Básico. As informações apresentadas nesse capítulo constam no sítio oficial da ENEF: http://www.vidaedinheiro.gov.br, bem como em decretos e leis.

No quarto capítulo abordaremos o objetivo principal do nosso trabalho, que é a apresentação de sugestões pedagógicas e metodológicas para o trabalho com Matemática Financeira (ainda que em um nível básico) no Ensino Fundamental, baseadas em nossa experiência com esse segmento de ensino. Nesse contexto, reforçaremos nosso entendimento sobre a importância da contextualização e faremos nossas considerações sobre tópicos que julgamos relevantes como alicerces ao letramento financeiro do educando, tais como habilidade numérica, porcentagem, juros, inflação e diversificação do risco.

O quinto capítulo trará nossas conclusões e considerações finais, bem como nossas sugestões para desenvolvimento de futuros trabalhos que possam contribuir para a discussão sobre o ensino de Matemática Financeira na Educação Básica.

No sexto e no sétimo capítulos apresentaremos, respectivamente, nossas referências bibliográficas para elaboração deste trabalho e os anexos.

\footnotetext{
${ }^{5}$ A Estratégia Nacional de Educação Financeira - ENEF - é uma mobilização multissetorial em torno da promoção de ações de educação financeira no Brasil. A estratégia foi instituída como política de Estado de caráter permanente e suas características principais são a garantia de gratuidade das iniciativas que desenvolve ou apoia e sua imparcialidade comercial.
} 


\section{Letramento Financeiro no mundo}

O aumento da expectativa de vida da população mundial trouxe à tona um problema identificado praticamente em todas as economias do planeta: a incapacidade das previdências sociais, muitas vezes deficitárias, em garantir bemestar, saúde e qualidade de vida aos seus segurados após a aposentadoria. A Figura 1 apresenta as variações de expectativa de vida em economias desenvolvidas e em nações de desenvolvimento próximo ao caso brasileiro, bem como a média dos países da Organização para a Cooperação e Desenvolvimento Econômico - $\mathrm{OCDE}^{6}$.

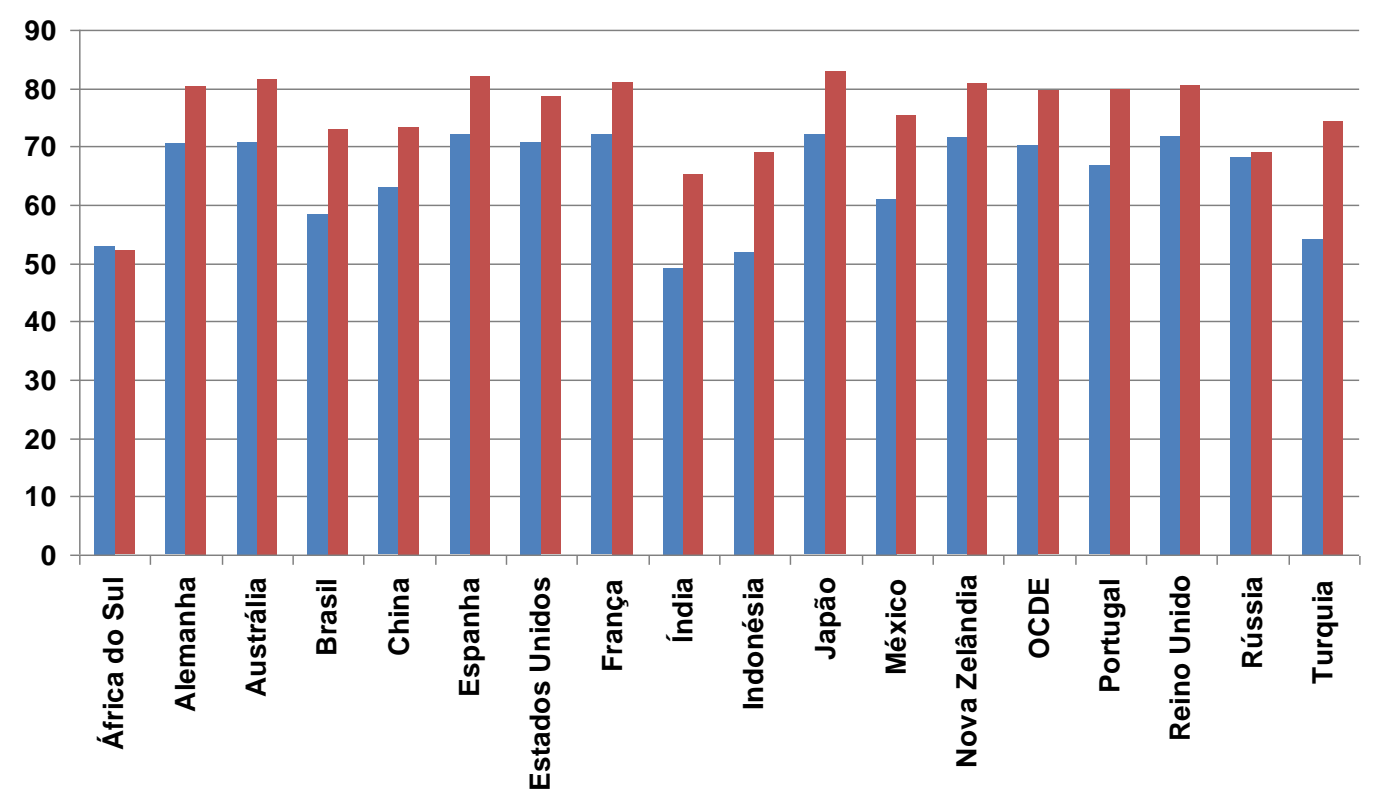

Expectativa de vida ao nascer (anos) - 1970 (ou primeiro ano disponível)

- Expectativa de vida ao nascer (anos) - 2010 (ou último ano disponível)

Figura 1 - Aumento da expectativa de vida no mundo.

Fonte: OECD. Life expectancy. In: OECD Factbook 2013: Economic, Environmental and Social Statistics, OECD Publishing, Paris. 2013.

\footnotetext{
${ }^{6}$ A Organização para a Cooperação e Desenvolvimento Econômico - OCDE, com sede em Paris, França, é um organismo composto por 34 membros. Atua nos âmbitos internacional e intergovernamental e reúne os países mais industrializados do mundo e alguns países emergentes, como México, Chile, Coreia do Sul e Turquia. No âmbito da OCDE, os representantes efetuam o intercâmbio de informações e alinham políticas, com o objetivo de potencializar seu crescimento econômico e colaborar com o desenvolvimento de todos os demais países membros.
} 
Em função do problema que envolve as previdências sociais, os governos vêm envidando esforços para incentivar aos cidadãos o hábito de poupar em longo prazo, reduzindo dessa forma a dependência das pessoas em relação aos programas sociais de previdência. Os jovens de hoje terão que ser capazes de se sustentar por longo tempo e esse cenário é observado globalmente.

Uma medida necessária para atingir este objetivo é o crescimento do letramento financeiro das populações mundiais.

\section{1}

\section{Letramento Financeiro nos Estados Unidos}

Lusardi e Mitchell (2014) definem o letramento financeiro como a capacidade de os indivíduos processarem informações econômicas e tomarem decisões que envolvam planejamento financeiro, enriquecimento, dívidas e pensões. As autoras desenvolveram um estudo para avaliar o nível de letramento financeiro da população estadunidense e de vários outros países.

Vários conceitos fundamentais estão na raiz das decisões que envolvem poupança e investimento. Três desses conceitos são: (i) a compreensão dos números e capacidade de fazer cálculos relacionados com as taxas de juros, tais como juros compostos, que é o conceito básico de educação financeira; (ii) a compreensão da inflação, que afeta diretamente o poder de compra das pessoas e interfere na economia de um país; e (iii) a compreensão da diversificação do risco, considerando que toda decisão financeira tem a ver com o futuro e este é incerto.

Traduzir esses conceitos em métricas para avaliar o nível de letramento financeiro de uma população não é uma tarefa fácil, mas Lusardi e Mitchell (2008, 2011a, 2011b) desenharam um conjunto padronizado de perguntas em torno dessas ideias e implementaram-no em várias pesquisas nos Estados Unidos e no exterior.

As perguntas foram estruturadas segundo quatro princípios. O primeiro é a simplicidade: as perguntas devem medir os conhecimentos fundamentais para a tomada de decisões em um ambiente intertemporal. O segundo é a relevância: as perguntas devem relacionar conceitos pertinentes às decisões das pessoas no diaa-dia financeiro ao longo da vida. Além disso, elas devem enquadrar-se em um 
contexto geral e em ideias, ao invés de um contexto específico e em conteúdo. O terceiro é a brevidade: o número de perguntas deve ser curto para garantir a adoção generalizada. O quarto é a capacidade de diferenciação: as perguntas devem permitir a avaliação do conhecimento financeiro das pessoas e com isso permitir comparações entre elas.

Estes princípios são atendidos por três questões que tratam de letramento financeiro, propostas por Lusardi e Mitchell (2008, 2011a) originalmente em inglês e abaixo apresentadas em tradução livre ${ }^{7}$.

1) Suponha que você tinha $\$ 100$ em uma conta de poupança e a taxa de juros foi de $2 \%$ ao ano. Após cinco anos, quanto você acha que você teria na conta, se você deixou o dinheiro crescer:

A) mais de \$102; B) exatamente \$102; C) menos de \$102; D) não sei; E) recuso-me a responder.

2) Imagine que a taxa de juros em sua conta de poupança foi de $1 \%$ ao ano e a inflação foi de $2 \%$ ao ano. Após um ano, você seria capaz de comprar:

A) mais do que, B) exatamente o mesmo que, C) menos do que hoje, com o dinheiro dessa conta; D) não sei; E) recuso-me a responder.

3) Você acha que a seguinte declaração é verdadeira ou falsa? "Comprar ações de uma única empresa normalmente fornece um retorno mais seguro do que um fundo mútuo de ações”.

A) verdadeiro; B) falso; C) não sei; D) recuso-me a responder.

A primeira questão avalia a capacidade de fazer um cálculo simples relacionado a taxas de juros. A segunda pergunta investiga a compreensão da

\footnotetext{
${ }^{7}$ As perguntas originalmente apresentadas foram: 1. Suppose you had $\$ 100$ in a savings account and the interest rate was 2 percent per year. After five years, how much do you think you would have in the account if you left the money to grow? A) more than \$102; B) exactly \$102; C) less than $\$ 102$; D) do not know; E) refuse to answer. 2. Imagine that the interest rate on your savings account is 1 percent per year and inflation is 2 percent per year. After one year, would you be able to buy A) more than, B) exactly the same as, or C) less than today with the money in this account?; D) do not know; E) refuse to answer. 3. Do you think that the following statement is true or false? "Buying a single company stock usually provides a safer return than a stock mutual fund." A) true; B) false; C) do not know; D) refuse to answer.
} 
inflação, novamente no contexto de uma decisão meramente financeira. A terceira questão verifica o conhecimento sobre "ações", "fundos de ações" e a diversificação do risco, uma vez que a resposta a esta questão depende de saber o que é uma ação e que um fundo mútuo é composto de unidades diversas de ações. Obviamente, muitas decisões sobre poupança devem lidar com o conhecimento sobre os mercados financeiros. Assim, é importante avaliar, ainda que minimamente, o nível de conhecimento do entrevistado sobre esse mercado.

A respeito da terceira pergunta, é bom salientar que o envolvimento da população estadunidense com o mercado financeiro e, em especial, com ações e fundos mútuos de ações é conhecidamente superior ao cenário encontrado no Brasil, de modo que a última das três questões apresentadas guarda pouca pertinência com a realidade brasileira. Entretanto, o conceito de compreensão da diversificação do risco foi tratado por meio de questão mais genérica e, portanto, menos associada à realidade estadunidense, em estudo posterior, que será detalhado mais a frente.

As três perguntas propostas por Lusardi e Mitchell (2008, 2011a) e acima reproduzidas foram administradas primeiro a uma amostra representativa de entrevistados estadunidenses com idades em torno de 50 anos, em um módulo especial do Health and Retirement Study 2004 (HRS) ${ }^{8}$. Os resultados, resumidos na Tabela 1, demonstraram que esta população estadunidense mais velha é dotada de letramento financeiro insuficiente, pois cerca de metade conseguiu responder o cálculo simples que tratava de juros compostos de $2 \%$ e sabia sobre a inflação, além de apenas um terço ter respondido as três perguntas corretamente (LUSARDI e MITCHELL, 2011a).

Esse resultado torna-se mais preocupante considerando que as pessoas nessa faixa etária já haviam tomado muitas decisões financeiras ao longo de suas vidas. Além disso, esses entrevistados tinham experimentado dois ou três períodos de inflação alta (dependendo da idade) e testemunharam grandes crises no mercado de ações, incluindo o escândalo financeiro que, em função de manipulação de balanços e outras fraudes contábeis e fiscais, ocasionou a falência

\footnotetext{
${ }^{8}$ Estudo realizado a cada dois anos pela Universidade de Michigan nos Estados Unidos, com uma amostra representativa de cerca de 20.000 pessoas em torno de 50 anos, que explora as mudanças na participação na força de trabalho e as transições de saúde com a chegada da aposentadoria e nos anos que se seguem.
} 
da Enron ${ }^{9}$, o que deveria ter-lhes fornecido informações sobre o risco de investimento. A questão sobre o risco foi aquela em que os entrevistados escolheram em grande número a opção "não sei”.

Tabela 1 - Letramento financeiro nos Estados Unidos.

Parte A. Distribuição de respostas às questões de letramento financeiro

\begin{tabular}{lcccc} 
& \multicolumn{4}{c}{ Respostas } \\
\cline { 2 - 5 } & Correta & Incorreta & Não soube & $\begin{array}{c}\text { Não } \\
\text { respondeu }\end{array}$ \\
\hline Juros compostos & $67,1 \%$ & $22,2 \%$ & $9,4 \%$ & $1,3 \%$ \\
Inflação & $75,2 \%$ & $13,4 \%$ & $9,9 \%$ & $1,5 \%$ \\
Diversificação do risco & $52,3 \%$ & $13,2 \%$ & $33,7 \%$ & $0,9 \%$ \\
\hline Parte B. Probabilidades & conjuntas & de & se & responder \\
corretamente & & & questões de letramento & financeiro \\
& Todas as três & Apenas duas & Apenas uma & Sem \\
& respostas & respostas & resposta & respostas \\
& corretas & corretas & correta & corretas \\
\cline { 2 - 5 } & $34,3 \%$ & $35,8 \%$ & $16,3 \%$ & $9,9 \%$ \\
\hline
\end{tabular}

Fonte: Lusardi, Annamaria, and Olivia S. Mitchell. 2014. "The Economic Importance of Financial Literacy: Theory and Evidence". Journal of Economic Literature, 52(1): 5-44.

Segundo Lusardi e Mitchell (2014), estas mesmas questões foram utilizadas em várias outras pesquisas nos EUA posteriormente, incluindo a 20072008 National Longitudinal Survey of Youth - NLSY, para jovens com idades entre 23 e 28 anos (Lusardi, Mitchell e Curto, 2010); o RAND American Life Panel - ALP, para pessoas de todas as idades (Lusardi e Mitchell, 2009); e o 2009 and 2012 National Financial Capability Study (Lusardi e Mitchell, 2011c), para pessoas adultas. Não obstante, os resultados demonstraram um nível de letramento financeiro bastante baixo para todos os grupos.

\footnotetext{
${ }^{9}$ O escândalo da Enron foi tão impactante e noticiado que foi determinante para a criação da lei Sarbanes-Oxley (conhecida como Sarbox ou SOX), que teve por objetivo privilegiar a transparência, a auditoria e a governança corporativa, buscando evitar o surgimento de fraudes ou, ao menos, criar mecanismos para identificá-las.
} 


\section{2}

\section{Pesquisa sobre Educação Financeira Global da S\&P (The S\&P Global FinLit Survey)}

Tendo sido apresentadas estas importantes informações acerca do trabalho realizado pelas professoras AnnaMaria Lusardi e Olivia Mitchell, é conveniente também considerar uma abrangente pesquisa realizada em 2014 pela Standard \& Poor's Ratings Services ${ }^{10}$, em conjunto com a Gallup, o World Bank Development Research Group e o Global Financial Literacy Excellence Center GFLEC da George Washington University School of Business.

Consideraremos ainda o trabalho intitulado "Financial Literacy Around the World: Insights from the Standard \& Poor's Ratings Services Global Financial”, produzido por Leora Klapper (World Bank Development Research Group), Annamaria Lusardi (The George Washington University School of Business) e Peter van Oudheusden (World Bank Development Research Group), o qual apresenta conclusões relevantes sobre a pesquisa anteriormente realizada pela Standard \& Poor's Ratings Services.

A Pesquisa sobre Educação Financeira Global da S\&P (The S\&P Global FinLit Survey) é a maior e mais abrangente avaliação de educação financeira já realizada até então (LUSARDI, 2015).

O estudo buscou medir o nível de letramento financeiro da população adulta mundial, considerando a compreensão dos entrevistados sobre alguns conceitos de letramento financeiro que foram considerados básicos pelos realizadores do estudo.

A população da pesquisa foi composta por indivíduos com 15 anos ou mais, os quais foram considerados adultos para efeito dessa pesquisa. Foram entrevistadas mais de 150.000 pessoas, em uma amostra nacionalmente representativa e aleatória, em mais de 140 países, durante o ano civil de 2014. As pesquisas foram realizadas presencialmente nas economias em que menos de $80 \%$

\footnotetext{
${ }^{10}$ A Standard \& Poor's Ratings Services assim se apresenta em seu sítio oficial: "com 26 escritórios em todo o mundo e uma história de mais de 150 anos, a Standard \& Poor's Ratings Services oferece inteligência de mercado de alta qualidade na forma de ratings de crédito e pesquisas".
} 
da população tem acesso a um telefone ou com a metodologia habitual, nos demais casos.

O letramento financeiro foi medido utilizando perguntas formuladas pelos autores da pesquisa, os quais pretendiam avaliar os conhecimentos básicos dos entrevistados sobre quatro conceitos que consideraram fundamentais na tomada de decisão financeira: habilidade numérica (no contexto de cálculos de taxas de juros), juros compostos, inflação e diversificação de riscos.

As perguntas seguem abaixo transcritas em tradução livre ${ }^{11}$ :

1. Suponha que você precise tomar emprestado $\$ 100$. Qual é a quantia mais baixa para devolver: $\$ 105$ ou $\$ 100$ mais 3\%? [ $\$ 105 ; \$ 100$ mais $3 \%$; não sei; recuso-me a responder].

2. Suponha que você guarde dinheiro no banco por dois anos, e o banco vai incluir $15 \%$ ao ano à sua conta. O banco adicionará MAIS dinheiro no segundo ano à sua conta do que no primeiro ano ou adicionará a MESMA quantidade de dinheiro nos dois anos? [mais; o mesmo; não sei; recuso-me a responder]

3. Suponha que você tinha $\$ 100$ em uma conta poupança e o banco adicionou $10 \%$ ao ano à sua conta. Quanto você teria na conta, após cinco anos, se não tirasse nenhum dinheiro da conta? [mais de \$150; exatamente $\$ 150$; menos de $\$ 150$; não sei; recuso-me a responder].

4. Suponha que o preço das coisas que você compra hoje duplique em 10 anos. Se sua renda TAMBÉM duplicar, você conseguirá comprar menos, a mesma quantidade OU mais do que você compra hoje? [menos; a mesma quantidade; mais; não sei; recuso-me a responder].

\footnotetext{
${ }^{11}$ As perguntas originalmente apresentadas foram: 1. Suppose you need to borrow 100 dollars. Which is the lower amount to pay back: 105 dollars or 100 dollars plus three percent? 2. Suppose you put money in the bank for two years and the bank agrees to add 15 percent per year to your account. Will the bank add MORE money to your account the second year than it did the first year, or will it add the SAME amount of money both years? 3. Suppose you had 100 dollars in a savings account and the bank adds 10 percent per year to the account. How much money would you have in the account after five years if you did not remove any money from the account: more than 150 dollars, exactly 150 dollars, or less than 150 dollars? 4 . Suppose over the next 10 years the prices of the things you buy double. If your income ALSO doubles, will you be able to buy less than you can buy today, the same as you can buy today, OR more than you can buy today? 5 . Suppose you have some money. Is it safer to put your money into one business or investment, or to put your money into multiple businesses or investments?
} 
5. Suponha que você tem algum dinheiro. É mais seguro colocar seu dinheiro em um negócio ou investimento ou colocar seu dinheiro em vários negócios ou investimentos? [um negócio ou investimento; vários negócios ou investimentos; não sei; recuso-me a responder].

A primeira pergunta avalia a habilidade numérica do entrevistado em realizar o cálculo simples de 3\% sobre $\$ 100$ e adicioná-lo ao valor, identificando que o resultado é inferior a $\$ 105$.

A segunda e terceira perguntas avaliam o conhecimento do entrevistado no que tange a juros compostos, considerando aplicações com rendimentos anuais em períodos de dois e cinco anos.

A quarta pergunta investiga o conhecimento do entrevistado acerca de inflação e a sua relação direta de interferência no poder de compra, quando os salários (ou rendimentos) recebidos pelas pessoas não a acompanham.

A quinta pergunta trata do conhecimento do entrevistado sobre diversificação de riscos, no sentido de representar maior segurança para o indivíduo a participação em vários investimentos ou negócios, em oposição a “colocar todos os seus ovos em um único cesto".

É importante destacar que as cinco perguntas descritas acima serão retomadas no capítulo 4, quando analisaremos detalhadamente cada uma delas.

Nessa pesquisa, uma pessoa é definida como letrada financeiramente quando ela responde de forma correta as perguntas relacionadas a, pelo menos, três dos quatro conceitos financeiros descritos acima. Essa definição foi escolhida pelos realizadores do estudo por considerarem que os conceitos são básicos, de modo que seria necessário a um participante entender adequadamente pelo menos três conceitos para revelar letramento apropriado.

O objetivo do estudo foi o fornecimento de dados importantes para desenvolvedores de políticas públicas, reguladores, setor privado e meio acadêmico, no sentido de ajudá-los a entender o conhecimento atual das pessoas sobre conceitos financeiros básicos.

Os resultados são alarmantes. Com base na definição apresentada, 33\% dos adultos no mundo são financeiramente letrados. Isto significa que a carência de letramento financeiro atinge dois em cada três adultos no mundo, ou seja, cerca de 4,7 bilhões de adultos em todo o mundo não têm uma compreensão dos 
conceitos básicos de letramento financeiro. Estes números globais escondem profundas disparidades em todo o mundo, como revela o mapa apresentado na Figura 2.

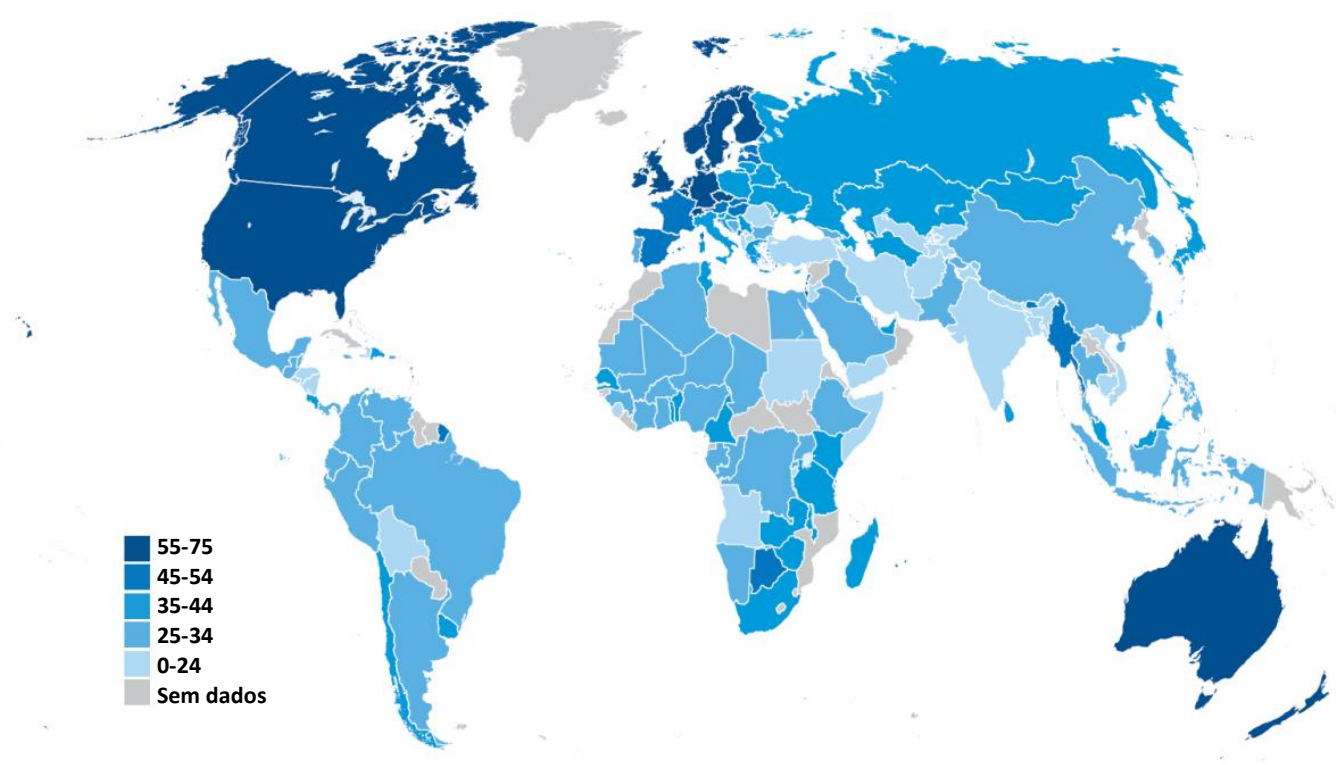

Figura 2 - Percentual de adultos letrados financeiramente no mundo Fonte: S\&P Global FinLit Survey

O que pode ser verificado na Figura 2 é que o letramento financeiro está distribuído de forma heterogênea, com grandes variações entre países.

$\mathrm{Na}$ classificação global, Noruega, Dinamarca e Suécia lideram entre os mais letrados financeiramente, com $71 \%$ dos adultos tendo respondido corretamente, pelo menos, as perguntas de três dos quatro conceitos de letramento financeiro avaliados.

Uma das maiores potências econômicas mundiais, os Estados Unidos, ficaram com a décima quarta colocação, com 57\% dos adultos financeiramente letrados.

No Brasil, 35\% foram considerados financeiramente letrados. O índice de letramento financeiro dos brasileiros encontra-se próximo da média mundial. $\mathrm{O}$ resultado coloca o Brasil na sexagésima sétima posição entre os países analisados.

A Tabela 2 destaca os resultados para alguns países participantes, por ordem de classificação. São apresentadas as cinco economias com melhor desempenho e as cinco economias com pior desempenho, bem como nações 
desenvolvidas importantes e países com desenvolvimento próximo ao caso brasileiro.

Tabela 2 - Adultos com letramento financeiro em economias selecionadas.

\begin{tabular}{|c|c|c|c|}
\hline & Colocação & Economia & $\begin{array}{l}\text { Adultos com } \\
\text { letramento } \\
\text { financeiro (\%) }\end{array}$ \\
\hline & 1 & Dinamarca & 71 \\
\hline & 1 & Noruega & 71 \\
\hline & 1 & Suécia & 71 \\
\hline & 4 & Canadá & 68 \\
\hline & 4 & Israel & 68 \\
\hline & 6 & Reino Unido & 67 \\
\hline & 7 & Alemanha & 66 \\
\hline & 9 & Austrália & 64 \\
\hline & 11 & Nova Zelândia & 61 \\
\hline & 14 & Estados Unidos & 57 \\
\hline & 23 & França & 52 \\
\hline & 26 & Espanha & 49 \\
\hline & 38 & Japão & 43 \\
\hline & 40 & África do Sul & 42 \\
\hline & 54 & Rússia & 38 \\
\hline & 67 & Brasil & 35 \\
\hline & 84 & Indonésia & 32 \\
\hline & 84 & México & 32 \\
\hline & 97 & China & 28 \\
\hline & 107 & Portugal & 26 \\
\hline & 116 & Índia & 24 \\
\hline & 116 & Turquia & 24 \\
\hline $\bar{D}$ & 139 & Angola & 15 \\
\hline & 139 & Somália & 15 \\
\hline & 141 & Afeganistão & 14 \\
\hline & 141 & Albânia & 14 \\
\hline & 143 & lêmen & 13 \\
\hline
\end{tabular}

Fonte: S\&P Global FinLit Survey.

De acordo com a pesquisa, ainda que o letramento financeiro da população tenha sido considerado baixo em geral, identificou-se que o nível de letramento financeiro nos países desenvolvidos é maior do que nas principais economias consideradas emergentes, com destaque para o grupo conhecido como BRICS ${ }^{12}$, no qual está incluído o Brasil, o que pode ser observado nos gráficos apresentados na Figura 3.

\footnotetext{
${ }^{12}$ BRICS é um acrônimo que se refere ao grupo formado pelos seguintes países considerados emergentes: Brasil, Rússia, Índia, China e África do Sul. Estas nações formam um grupo político de cooperação e estão em um nível similar de desenvolvimento econômico.
} 


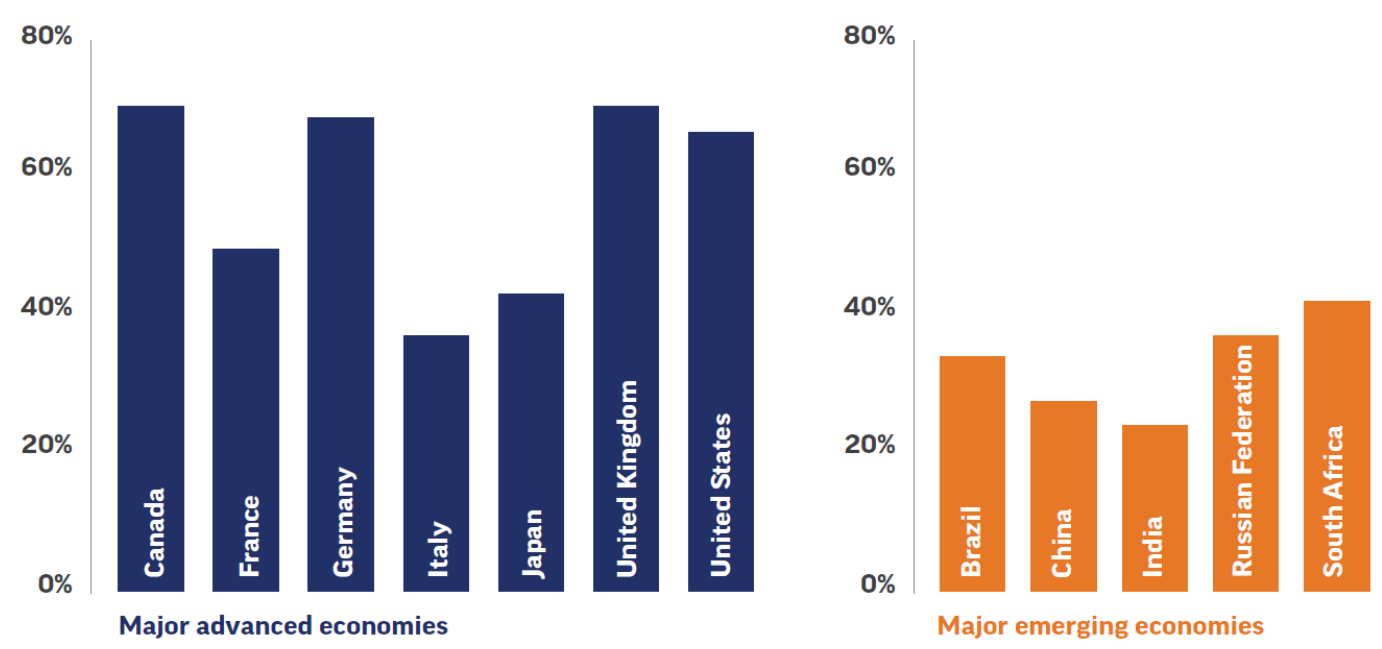

Figura 3 - Letramento financeiro nos países desenvolvidos e nos países emergentes. Fonte: S\&P Global FinLit Survey.

Além disso, foram observadas variações sobre grau de conhecimento financeiro do grupo avaliado de acordo com gênero, renda, nível educacional e idade.

Conforme se observa na Figura 4, em todo o mundo, 35\% dos homens são financeiramente letrados, em comparação com $30 \%$ das mulheres. Na mesma figura é possível notar que esta diferença de gênero é encontrada nas economias avançadas e nas economias emergentes, tomando como referência as nações apresentadas na Figura 3. Como também se verifica na Figura 4, da mesma maneira que as mulheres são menos propensas a dar respostas corretas para as questões de letramento financeiro, elas também são mais propensas a indicar que "não sabem" a resposta, o que as torna um alvo ideal para programas de educação financeira (LUSARDI, 2015). 

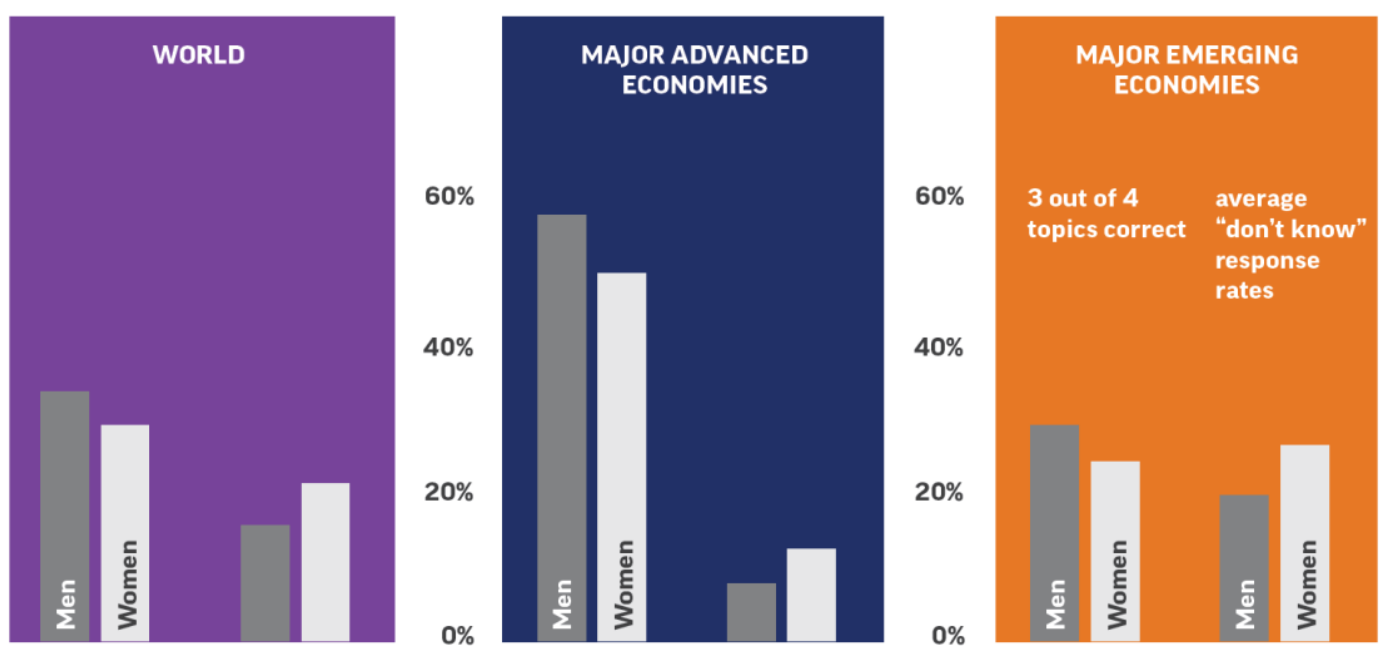

Figura 4 - Letramento financeiro entre os gêneros: percentual de adultos letrados financeiramente (com respostas corretas para pelo menos três de quatro conceitos) ou "não sei".

Fonte: S\&P Global FinLit Survey.

A pesquisa identificou que os adultos ricos têm melhores habilidades financeiras do que os pobres. Dos adultos das $60 \%$ residências mais ricas nas principais economias emergentes, $31 \%$ são letrados financeiramente, enquanto nas $40 \%$ residências mais pobres são apenas $23 \%$, o que pode ser verificado na Figura 5.
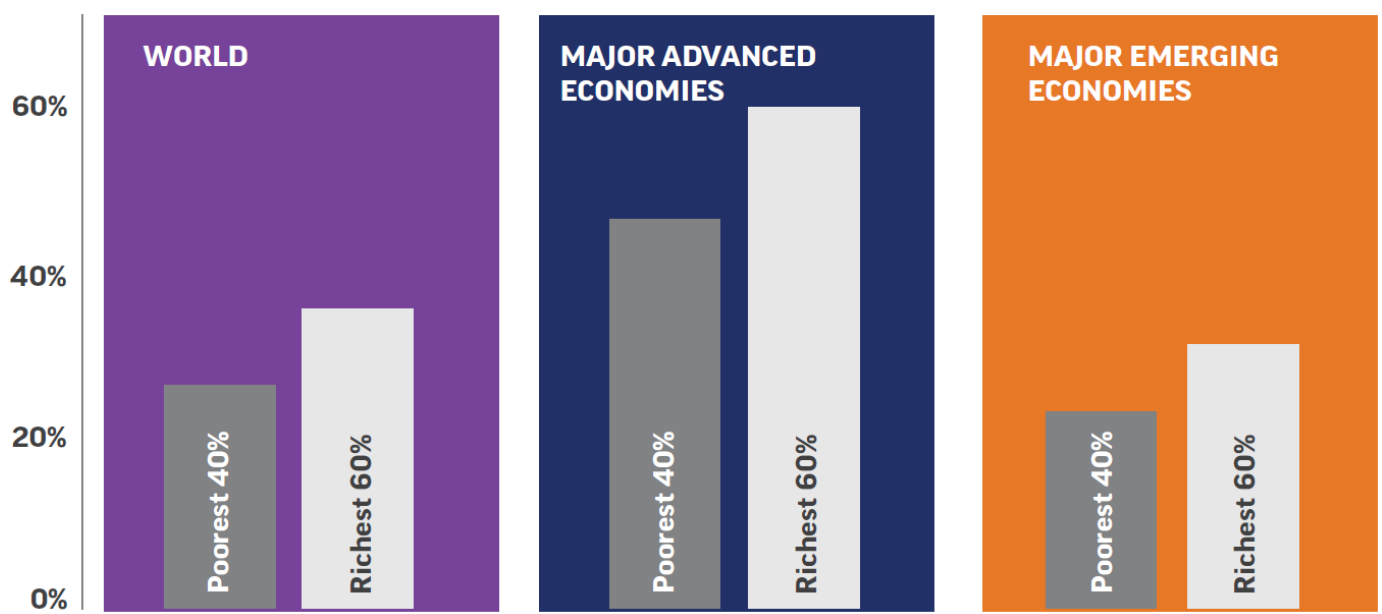

Figura 5 - Letramento financeiro e desigualdade de renda: percentual de adultos que são letrados financeiramente entre os $60 \%$ mais ricos e os $40 \%$ mais pobres. Fonte: S\&P Global FinLit Survey.

Nos países mais ricos, quanto maior o PIB per capita, as taxas de letramento financeiro tendem a ser maiores. No entanto, somente se verifica uma correlação positiva quando observadas as $50 \%$ economias mundiais mais ricas, conforme apresentado na Figura 6. Segundo Lusardi, Klapper e Oudheusden 
(2015), para as 50\% economias mundiais mais pobres, com um PIB per capita de \$12.000 ou menos, não há nenhuma evidência que a renda está associada ao letramento financeiro. Os autores acreditam ainda que isso provavelmente significa que políticas nacionais, como aquelas relacionadas à educação e proteção do consumidor, dão forma ao letramento financeiro nessas economias, mais do que qualquer outro fator.

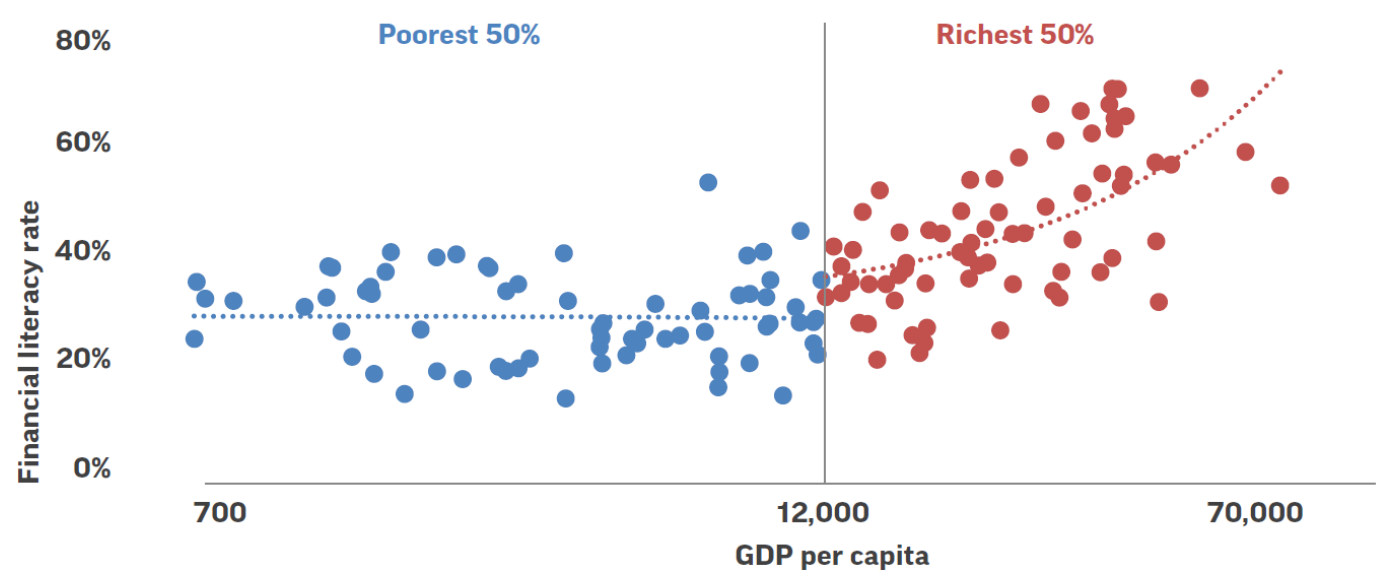

Figura 6 - Relação entre letramento financeiro e PIB per capita. Fonte: S\&P Global FinLit Survey and Global Findex database.

De acordo com a Figura 7, pode ainda ser acrescentado, que, para as principais economias avançadas, os adultos entre 36 e 50 anos possuem a maior taxa de letramento financeiro, que é de $63 \%$. O padrão é diferente entre as economias emergentes, em que o maior nível de letramento financeiro é observado entre aqueles que possuem entre 15 e 35 anos, aferido pela pesquisa como sendo de $32 \%$.

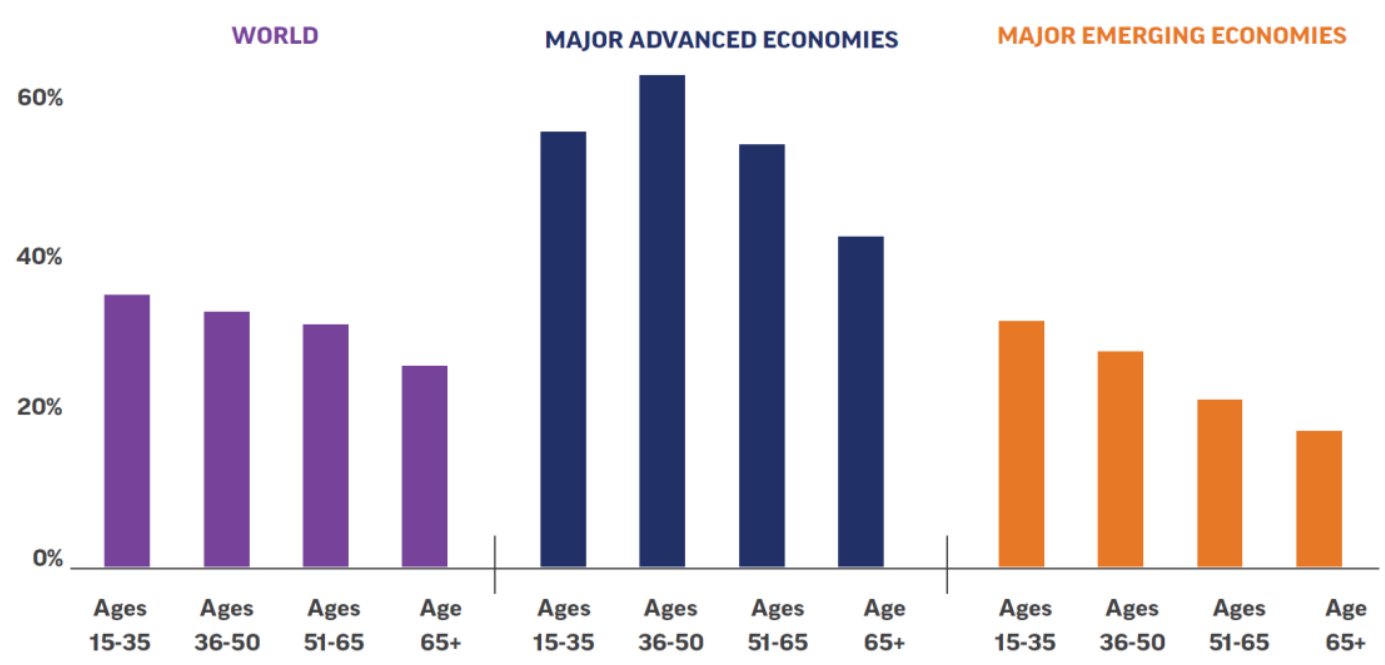

Figura 7 - Letramento financeiro por faixa etária. Fonte: S\&P Global FinLit Survey. 
A Figura 8 apresenta que, entre os quatro temas escolhidos para definir o letramento financeiro, a inflação e habilidade numérica (no contexto de cálculos de taxas de juros) são os mais entendidos. No mundo todo, metade da população adulta entende esses conceitos. $\mathrm{O}$ conceito sobre diversificação de riscos foi o que demonstrou ser menos entendido pela população, com apenas $35 \%$ dos adultos tendo respondido corretamente a pergunta. Entretanto, nota-se grande disparidade na compreensão desse conceito entre as economias desenvolvidas e as economias emergentes, com uma variação de 36 pontos percentuais entre elas. As diferenças para os outros conceitos são menos consideráveis, variando de 15 pontos percentuais para o conceito de inflação e 10 pontos percentuais para o conceito de juros compostos.

RISK DIVERSIFICATION

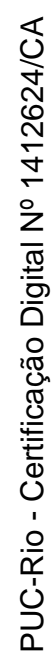

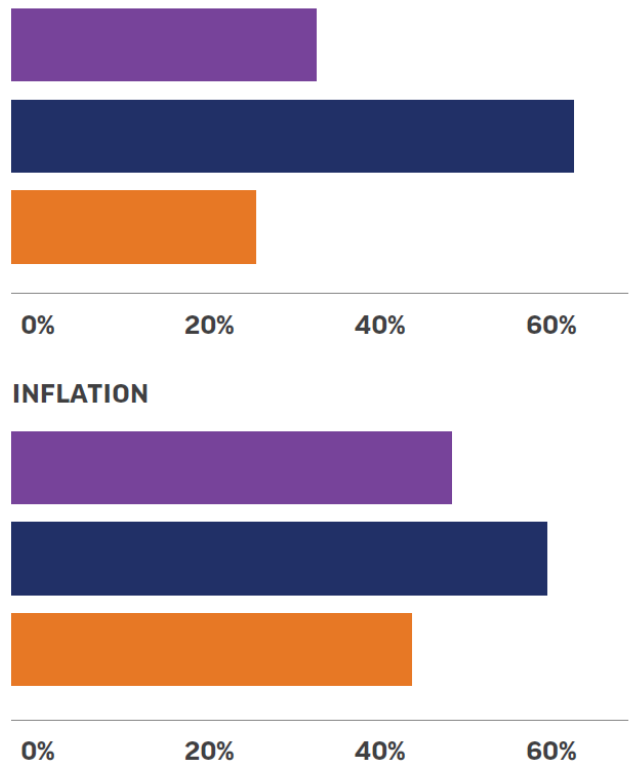

NUMERACY (INTEREST)

\section{World}

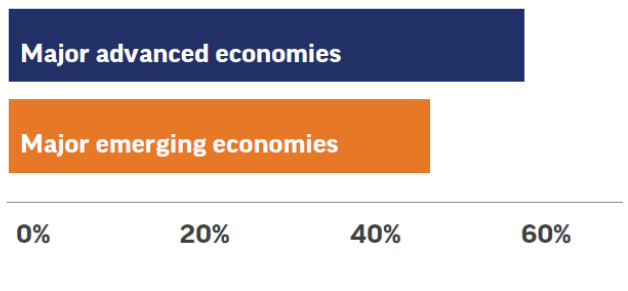

COMPOUND INTEREST

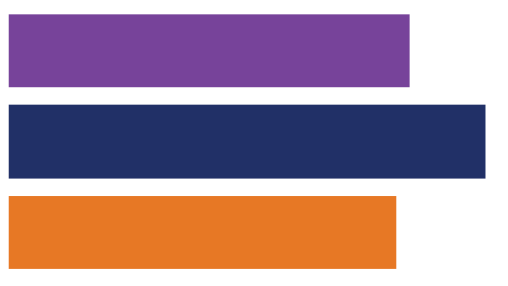

$0 \%$
$20 \%$

$40 \%$

$60 \%$

Figura 8 - Percentual de adultos com letramento financeiro por conceito. Fonte: S\&P Global FinLit Survey.

A pesquisa também pretendeu explorar a relação entre aqueles que são usuários de serviços financeiros - como as pessoas que possuem uma conta corrente, por exemplo - e aquelas que não estão inseridas nesse contexto.

Os resultados demonstraram que, embora os proprietários de contas tendam a ser financeiramente mais experientes, muitos deles ainda não podem ser considerados dotados de letramento financeiro. Globalmente, $38 \%$ entre os proprietários de conta são letrados financeiramente, assim como $57 \%$ entre os 
proprietários de conta nas principais economias desenvolvidas e $30 \%$ nas principais economias emergentes, tudo conforme a Figura 9, na qual a altura da barra representa a percentagem de adultos que possuem uma conta corrente. Segundo Lusardi (2015), foi observada uma correlação positiva entre o letramento financeiro e a inclusão financeira.

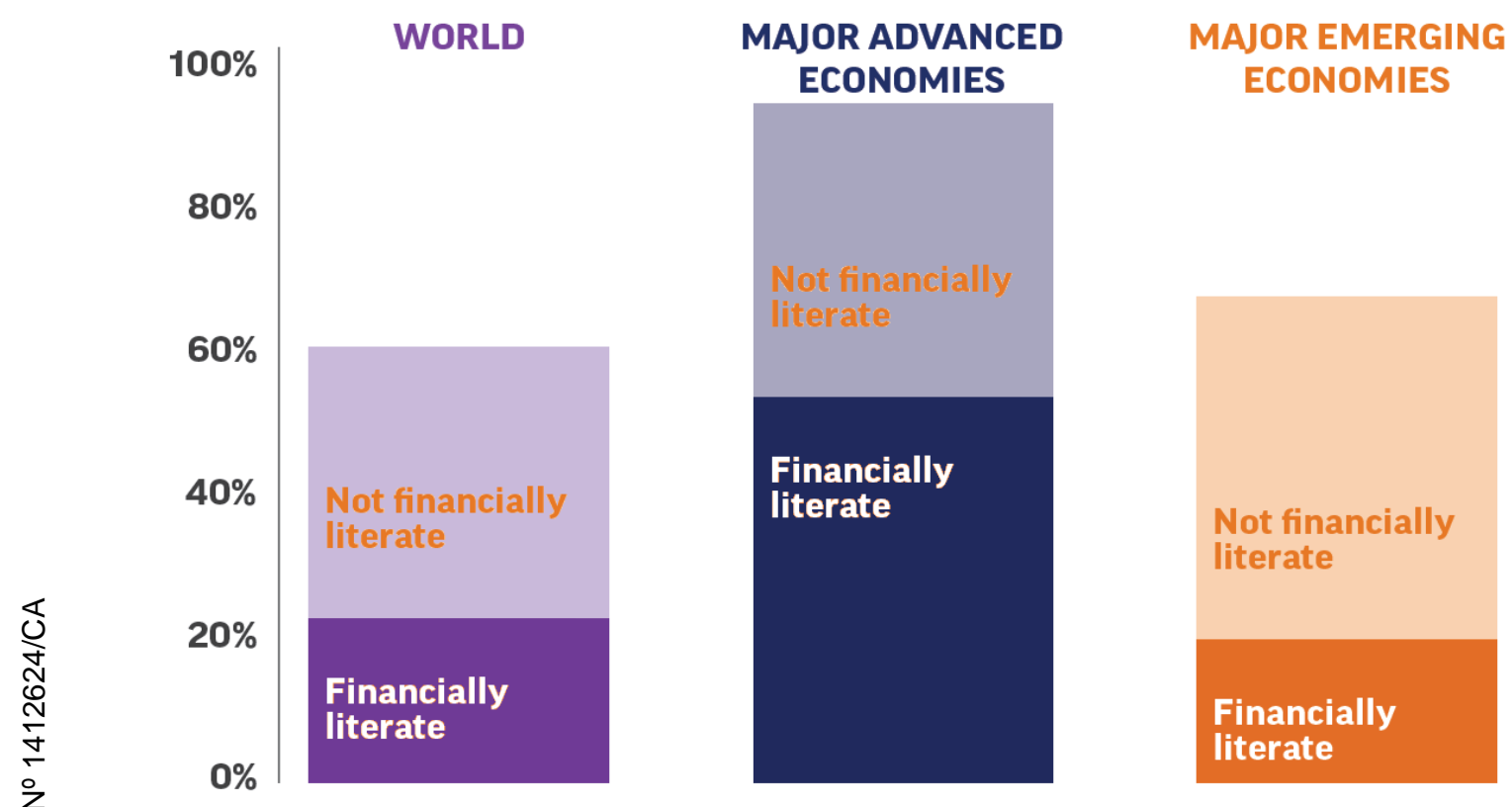

Figura 9 - Letramento financeiro de usuários de contas bancárias. Fonte: S\&P Global FINLIT Survey and Global Findex database.

\section{3}

\section{Letramento Financeiro e conhecimento matemático}

Um importante resultado da Pesquisa sobre Educação Financeira Global da S\&P diz respeito à comparação entre os resultados globais sobre o nível de letramento financeiro nos países e o resultado no exame de matemática PISA ${ }^{13}$ do ano de 2012.

Verifica-se, em geral, uma correlação positiva entre os conhecimentos de matemática dos jovens de uma nação e o grau de letramento financeiro da sua

\footnotetext{
${ }^{13}$ O Programme for International Student Assessment - PISA é um programa internacional desenvolvido e coordenado pela Organização para Cooperação e Desenvolvimento Econômico (OCDE), uma organização intergovernamental dos países industrializados. Nessa avaliação participam estudantes na faixa de 15 anos de idade, pois é pressuposto que nessa faixa etária o estudante já tenha terminado a escolaridade básica obrigatória na maioria dos países avaliados. Participam do PISA os 34 países membros da OCDE e vários países convidados.
} 
população, conforme apresentado na Figura 10. No entanto, conforme ponderam Lusardi, Klapper e Oudheusden (2015), alguns pontos atípicos são evidentes: China, Coreia do Sul, Portugal e Vietnã. Estas nações possuem baixas taxas de letramento financeiro em sua população, especialmente quando comparadas aos resultados no exame de matemática PISA. Realçam os autores que, na Coreia do Sul, 48\% dos adultos com 35 anos de idade ou menos são letrados financeiramente, enquanto apenas $27 \%$ o são na faixa etária de 51 a 65 anos. Para Portugal, continuam os autores, as taxas são $38 \%$ e $20 \%$, respectivamente. Sustentam os autores que estes achados podem sugerir que um bom desempenho em matemática pode ser benéfico para a compreensão de conceitos financeiros. Acrescentam que, em alguns países, um alto conhecimento matemático adquirido na juventude pode se transformar em um letramento financeiro também elevado na vida adulta.

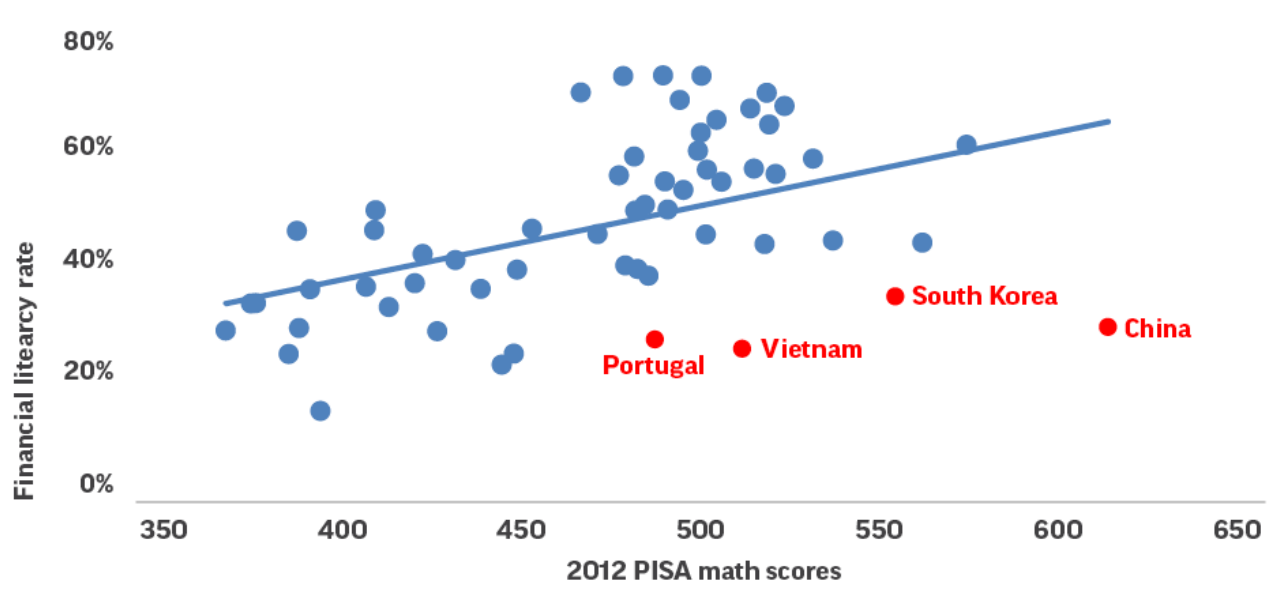

Figura 10 - Comparativo entre os resultados do exame de matemática do PISA 2012 e os resultados da Pesquisa Global.

Fonte: S\&P Global FinLit Survey and OECD PISA data (2014).

Os resultados apresentados indicam que a matemática está diretamente relacionada ao letramento financeiro, pois o aprendizado em finanças exige o conhecimento prévio de matemática. Neste sentido, afirmam Taylor e Wagland (2013) que a importância da matemática no currículo escolar não deve ser subestimada. Estes autores defendem que o conhecimento matemático fornece a plataforma fundamental sobre a qual construir o letramento financeiro do indivíduo e que isso poderia começar tão cedo quanto os anos de escola primária. 
Assim, além do fato de a habilidade em cálculo ser relevante para o ingresso e permanência dos jovens no mercado de trabalho, tudo parece indicar que serve também como instrumento básico para a tomada de decisões financeiras durante toda a vida.

\section{4}

\section{Letramento Financeiro no Brasil}

Tendo sido feitas considerações gerais sobre a Pesquisa sobre Educação Financeira Global da S\&P, principalmente comparando os resultados entre diversas economias mundiais, passaremos a examinar os resultados que tratam do Brasil no referido estudo.

Como já anteriormente mencionado, a Pesquisa sobre Educação Financeira Global da S\&P revelou que 35\% dos brasileiros possuem letramento financeiro, considerando que esse percentual dos entrevistados respondeu corretamente as perguntas de três dos quatro conceitos de letramento financeiro avaliados.

Conforme pode ser observado na Figura 11, entre os conceitos avaliados, habilidade numérica (no contexto de cálculos de taxas de juros) e inflação foram aqueles em que os brasileiros demonstraram maior conhecimento, com percentual de $56 \%$ e $53 \%$ de acertos, respectivamente, no que se refere às perguntas sobre os conceitos.

No que tange ao conceito de juros compostos, $46 \%$ dos entrevistados demonstrou possuir conhecimento sobre o assunto.

O conceito sobre diversificação de riscos foi confirmado ser o menos conhecido entre os brasileiros, com apenas 33\% de respostas corretas à pergunta, corroborando o resultado mundial de que tal conceito é o menos entendido pela população em geral. 


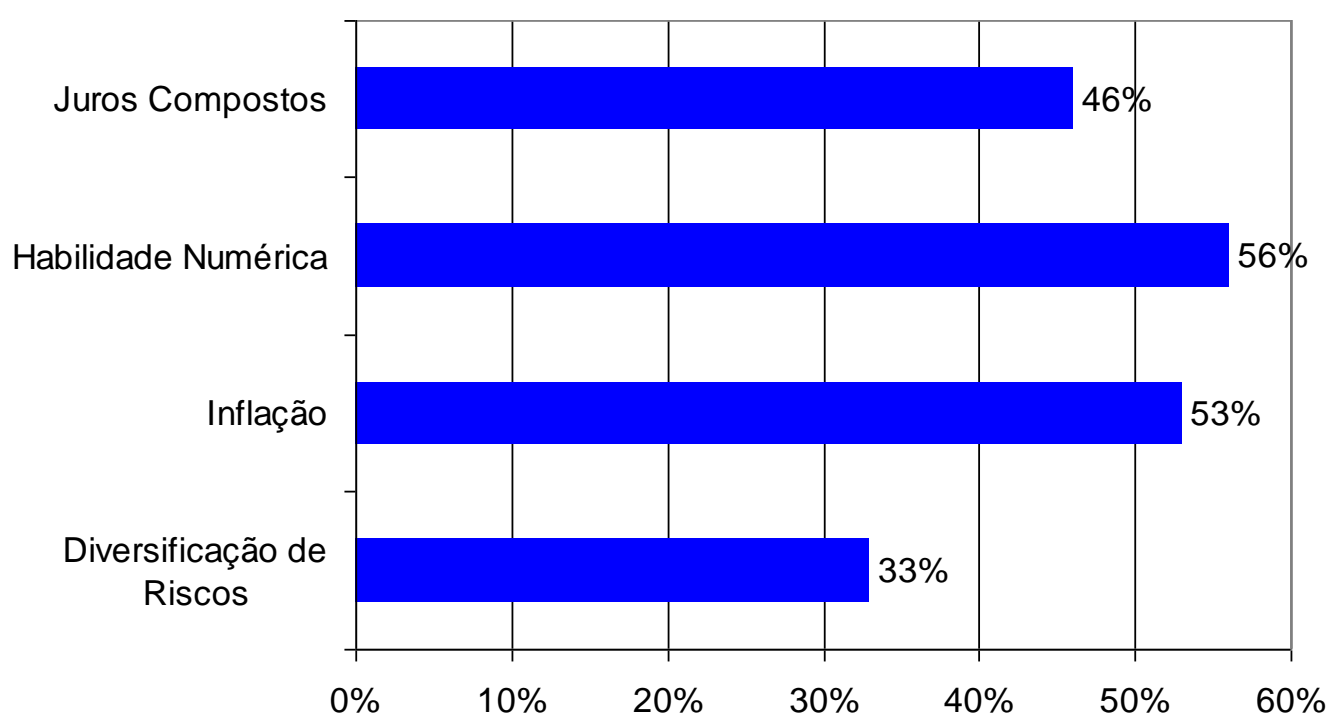

Figura 11 - Letramento financeiro no Brasil: percentual de acertos as perguntas por conceito avaliado.

Fonte: LUSARDI, Annamaria. Financial literacy: a global perspective. In: SEMINÁRIO DE EDUCAÇÃO FINANCEIRA PARA CRIANÇAS E JOVENS, 1., 2015, Rio de Janeiro.

No que diz respeito ao letramento financeiro entre os gêneros, a disparidade do letramento financeiro entre homens e mulheres no Brasil é de aproximadamente 13 pontos percentuais, conforme apresentado na Figura 12. Esta diferença é muito maior que a disparidade média entre homens e mulheres no resto do mundo, a qual ficou em torno de 5 pontos percentuais.

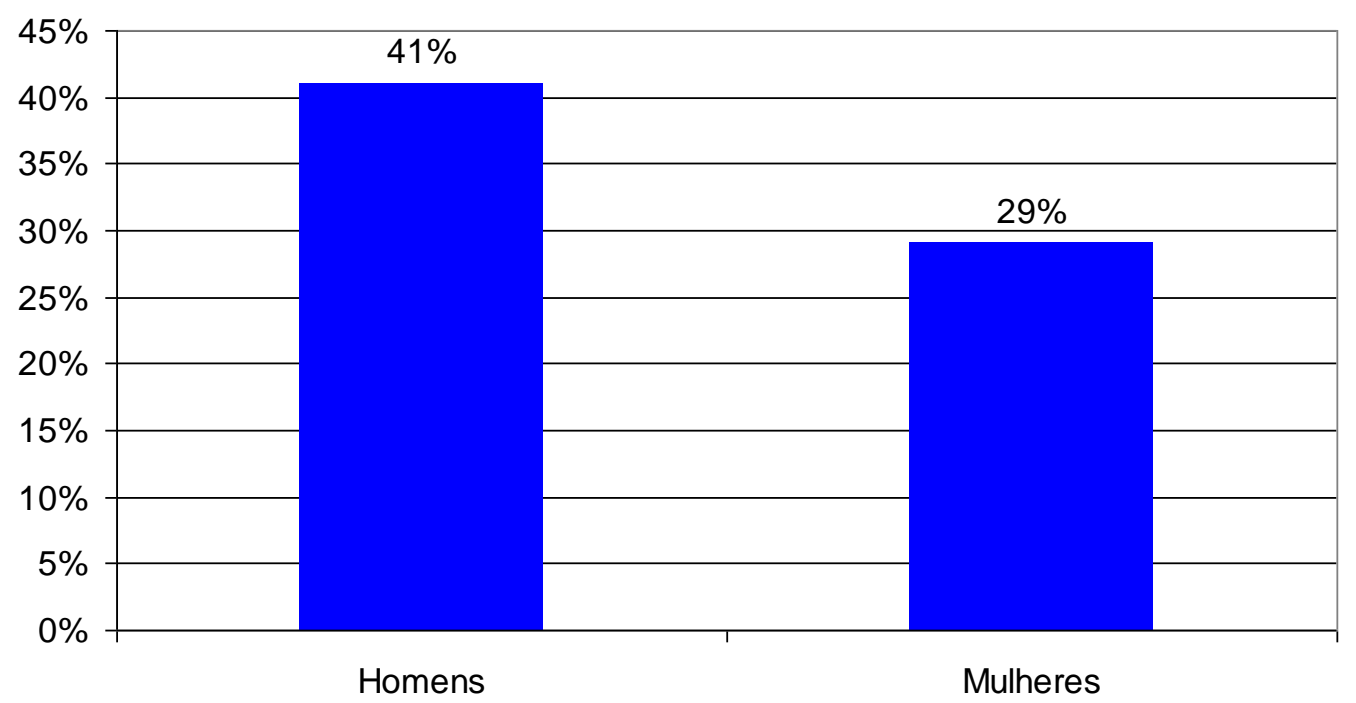

Figura 12 - Letramento financeiro entre os gêneros no Brasil. Fonte: LUSARDI, Annamaria. Financial literacy: a global perspective. In: SEMINÁRIO DE EDUCAÇÃO FINANCEIRA PARA CRIANÇAS E JOVENS, 1., 2015, Rio de Janeiro. 
Verifica-se na Figura 13, em relação ao letramento financeiro por faixa etária, que ficou demonstrado que, no Brasil, os adultos jovens entre 15 e 34 anos têm maior nível de letramento financeiro do que os participantes mais velhos. Entretanto, no geral, o nível de conhecimento financeiro é baixo.

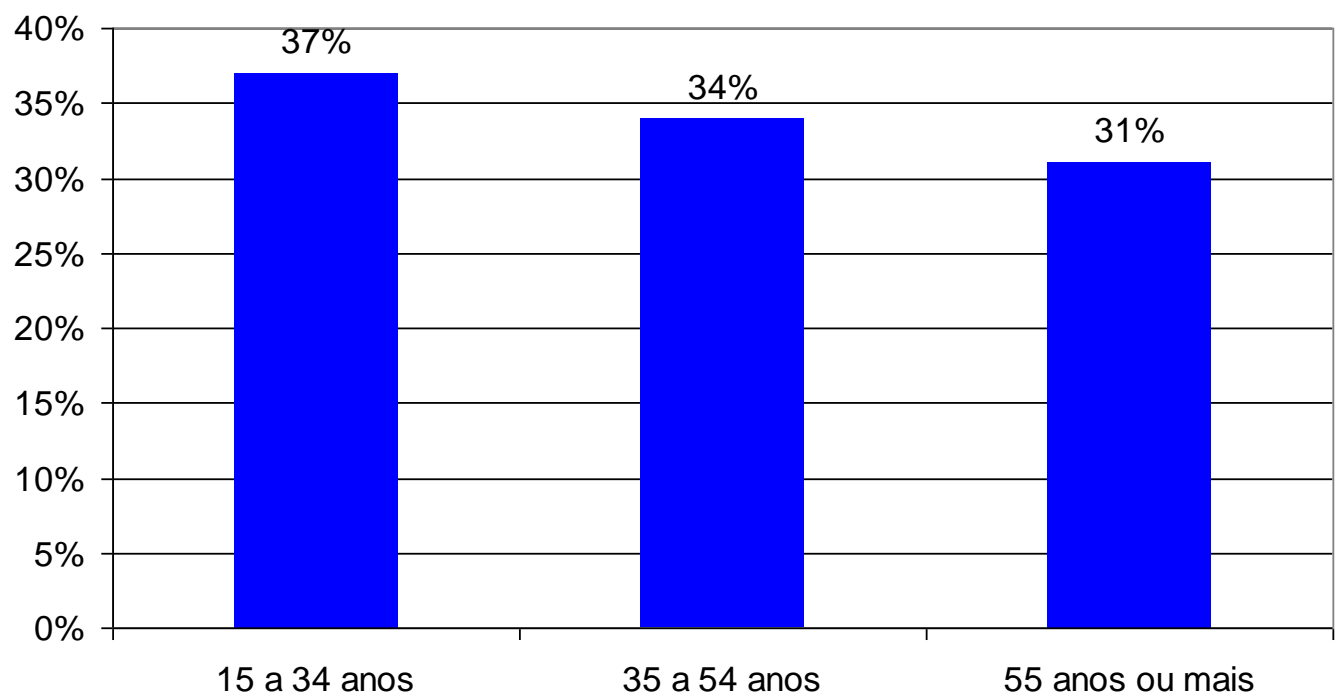

Figura 13 - Letramento financeiro por faixa etária no Brasil.

Fonte: LUSARDI, Annamaria. Financial literacy: a global perspective. In: SEMINÁRIO DE EDUCAÇÃO FINANCEIRA PARA CRIANÇAS E JOVENS, 1., 2015, Rio de Janeiro.

A pesquisa identificou que no Brasil, assim como no resto do mundo, os adultos ricos têm melhores habilidades financeiras do que os pobres. Dos adultos das $60 \%$ residências mais ricas, $38 \%$ são letrados financeiramente, enquanto nas $40 \%$ residências mais pobres, são apenas $29 \%$, o que pode ser verificado na Figura 14. 


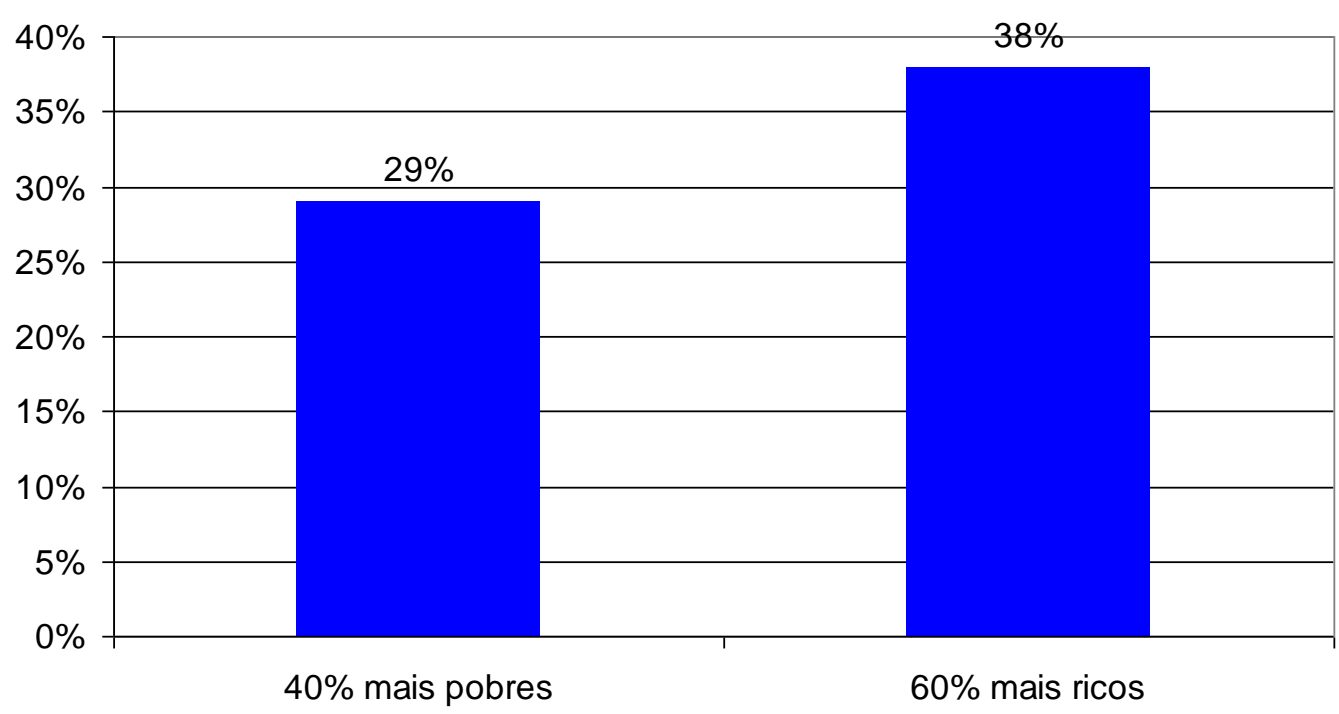

Figura 14 - Letramento financeiro e desigualdade de renda no Brasil.

Fonte: LUSARDI, Annamaria. Financial literacy: a global perspective. In: SEMINÁRIO DE EDUCAÇÃO FINANCEIRA PARA CRIANÇAS E JOVENS, 1., 2015, Rio de Janeiro.

\section{5}

\section{Avaliando os resultados}

A Pesquisa sobre Educação Financeira Global da S\&P originou uma quantidade expressiva de dados para compreender as diferenças no letramento financeiro no mundo.

Identificou-se que a carência de letramento financeiro atinge toda a população e que os jovens, idosos, mulheres e pessoas de baixa renda constituem um grupo vulnerável quando tratamos de letramento financeiro.

A pesquisa demonstrou ainda que o conceito sobre diversificação de riscos é o de mais difícil compreensão para os entrevistados.

Segundo Lusardi (2015), esses dados podem ser úteis para o estabelecimento de políticas e programas de educação financeira nos países. A autora sustenta que a carência difundida de letramento financeiro configura uma situação de crise, não sendo possível aplicar uma abordagem única para melhoria da situação. Para a autora, a solução do problema requer intervenções sólidas, sendo necessário haver programas direcionados, especialmente para grupos vulneráveis. Ela defende a criação de programas amplos e por etapas: educação 
financeira na escola, no local de trabalho e na comunidade - em bibliotecas, museus e outros lugares para os quais as pessoas vão para aprender.

Lusardi (2015) cita algumas evidências de que a educação financeira na escola contribui para a melhoria do nível de letramento financeiro de um povo e menciona algumas pesquisas já realizadas nesse sentido: a) Brown, Collins, Schmeiser e Urban (2014) relatam que, quando expostos a programas preparados com rigor e professores qualificados, os alunos se saem bem e têm menos probabilidade de terem problemas com dívidas; b) Walstad, Rebeck e MacDonald (2010) narram que tudo importa, quando tratamos de educação financeira: o conteúdo do curso, o volume de lições, as avaliações; e c) Tennyson e Nguyen (2001) expõem um trabalho em que alunos que foram obrigados a participarem de um curso de educação financeira se saíram melhor que os alunos que não participaram. 


\section{Estratégia Nacional de Educação Financeira - ENEF}

A crise econômica global de 2008 e as implicações sociais e econômicas em longo prazo do baixo índice de educação financeira de grande parte da população mundial motivaram o engajamento de vários governos nacionais a criar e consolidar políticas públicas voltadas especificamente para a educação financeira de sua população em geral (BRASIL, 2016a).

Em 2013, 45 países de diferentes níveis de renda criaram estratégias nacionais de educação financeira ou avançaram em projetos relacionados ao tema, com base na lista da Organização para a Cooperação e Desenvolvimento Econômico - OCDE (BRASIL, 2016a).

No âmbito dos países do G-20 ${ }^{14}$, de modo especial, as estratégias nacionais de educação financeira têm se proliferado. Cerca de metade deles já desenvolveram uma estratégia: Austrália, Brasil, Japão, Holanda, África do Sul, Espanha, Reino Unido e Estados Unidos (BRASIL, 2016a).

No caso do Brasil, uma iniciativa recente vem sendo desenvolvida, denominada Estratégia Nacional de Educação Financeira - ENEF.

A existência da ENEF favorece a difusão do tema no país e cria diretrizes para balizar iniciativas concretas, sejam do Estado, da iniciativa privada ou sociedade civil. A estratégia se torna a principal referência para leis, políticas públicas e programas multissetoriais, contribuindo para gerar ampla mobilização (BRASIL, 2016a).

\footnotetext{
${ }^{14}$ O G-20 é um fórum informal que promove debate aberto e construtivo entre países industrializados e emergentes sobre assuntos-chave relacionados à estabilidade econômica global. Criado em resposta às crises financeiras do final dos anos 90, o G-20 reflete mais adequadamente a diversidade de interesses das economias industrializadas e emergentes, possuindo assim maior representatividade e legitimidade. O Grupo conta com a participação de líderes de 19 países África do Sul, Alemanha, Arábia Saudita, Argentina, Austrália, Brasil, Canadá, China, Coreia do Sul, Estados Unidos, França, Índia, Indonésia, Itália, Japão, México, Reino Unido, Rússia e Turquia - e da União Europeia.
} 


\section{1}

\section{Histórico}

Em 2005, a OCDE motivada, entre outras razões, por pesquisas recentes nos países membros que demonstravam que os consumidores tinham baixo nível de letramento financeiro e falta de consciência da necessidade de serem financeiramente educados publicou um documento intitulado em tradução livre como "Recomendação sobre Princípios e Boas Práticas para Educação e Consciência Financeiras"15.

O documento listou sete princípios e dezenove boas práticas e convidou os membros e não membros a disseminarem as orientações aos setores públicos e privados envolvidos na educação e conscientização financeiras nos países.

De acordo com tal documento, gostaríamos de destacar o seguinte princípio recomendado: os programas de educação financeira ${ }^{16}$ devem ser projetados para atender às necessidades e o nível de letramento financeiro de seu público-alvo, bem como refletir a forma como seu público-alvo prefere receber informação financeira. A educação financeira deve ser considerada como um processo contínuo, permanente e ao longo da vida, de modo a levar em conta o aumento da complexidade dos mercados, as diferentes necessidades das distintas faixas etárias, e a crescente complexidade das informações ${ }^{17}$ (tradução livre, grifos nossos).

Destacamos ainda, a seguinte boa prática constante no documento: a educação financeira deve começar na escola. As pessoas devem ser educadas

\footnotetext{
${ }^{15} \mathrm{O}$ título original do documento foi: Recommendation on Principles and Good Practices for Financial Education and Awareness.

16 Segundo a OCDE (2005), a educação financeira é "o processo pelo qual consumidores e investidores melhoram sua compreensão sobre conceitos e produtos financeiros e, por meio de informação, instrução e orientação objetiva, desenvolvem habilidades e adquirem confiança para se tornarem mais conscientes das oportunidades e dos riscos financeiros, para fazerem escolhas bem informadas e saberem onde procurar ajuda ao adotarem outras ações efetivas que melhorem o seu bem-estar e a sua proteção (tradução livre)".

17 O princípio originalmente apresentado no documento foi: financial education programmes should be designed to meet the needs and the financial literacy level of their target audience, as well as reflect how their target audience prefers to receive financial information. Financial education should be regarded as a life-time, on-going and continuous process, in particular in order to take account of the increased complexity of markets, varying needs at different life stages, and increasingly complex information.
} 
sobre questões financeiras tão cedo quanto possível em suas vidas ${ }^{18}$ (tradução livre, grifos nossos).

Entre 2007 e 2010, o Comitê de Regulação e Fiscalização dos Mercados Financeiro, de Capitais, de Seguros, de Previdência e Capitalização COREMEC $^{19}$, por meio de um Grupo de Trabalho criado com o objetivo de coordenar os atos necessários à instituição de uma "Estratégia Brasileira de Educação Financeira", desenvolveu um trabalho que culminou com o Decreto Presidencial $\mathrm{n}^{\mathrm{o}}$ 7.397, de 22 de dezembro de 2010. A partir desse momento, a educação financeira adquiriu, no Brasil, estatuto de política de Estado.

O aludido decreto institui a Estratégia Nacional de Educação Financeira ENEF no Brasil e estabelece, em seu artigo $1^{\circ}$, que a ENEF tem como finalidade a promoção da educação financeira e previdenciária e contribuição para o fortalecimento da cidadania, a eficiência e solidez do sistema financeiro nacional e a tomada de decisões conscientes por parte dos consumidores (BRASIL, 2010a).

Tal decreto ainda constitui as diretrizes ${ }^{20}$ para implementação da ENEF e cria o Comitê Nacional de Educação Financeira - CONEF com o objetivo de definir planos, programas, ações e coordenar a execução da ENEF.

Para Nogueira (2016), hoje existe consenso de que melhores níveis de letramento financeiro podem contribuir para melhores decisões individuais, e que essas decisões, por sua vez, podem induzir efeitos positivos não apenas na esfera familiar, mas em uma estabilidade econômico-financeira bem mais abrangente.

Nessa linha, os objetivos de inserção da educação financeira nas escolas, propostos pela ENEF, são apresentados em dois grupos: os que se relacionam à dimensão espacial e os que se relacionam à dimensão temporal, como sugere o

\footnotetext{
${ }^{18}$ A boa prática originalmente apresentada no documento foi: financial education should start at school. People should be educated about financial matters as early as possible in their lives.

${ }^{19}$ O COREMEC tem caráter consultivo e é formado por dirigentes e representantes dos quatro reguladores do Sistema Financeiro Nacional: Banco Central do Brasil (BCB), Comissão de Valores Mobiliários (CVM), Superintendência Nacional de Previdência Complementar (PREVIC) e Superintendência de Seguros Privados (SUSEP).

${ }^{20}$ As diretrizes estabelecidas pelo artigo $2^{\circ}$ do Decreto $n^{\circ} 7.397$ de 2010 são: I - atuação permanente e em âmbito nacional; II - gratuidade das ações de educação financeira; III prevalência do interesse público; IV - atuação por meio de informação, formação e orientação; V centralização da gestão e descentralização da execução das atividades; VI - formação de parcerias com órgãos e entidades públicas e instituições privadas; e VII - avaliação e revisão periódicas e permanentes.
} 
diagrama da Figura 15, considerando que o cotidiano se passa sempre em espaço e tempo determinados (BRASIL, 2016f).

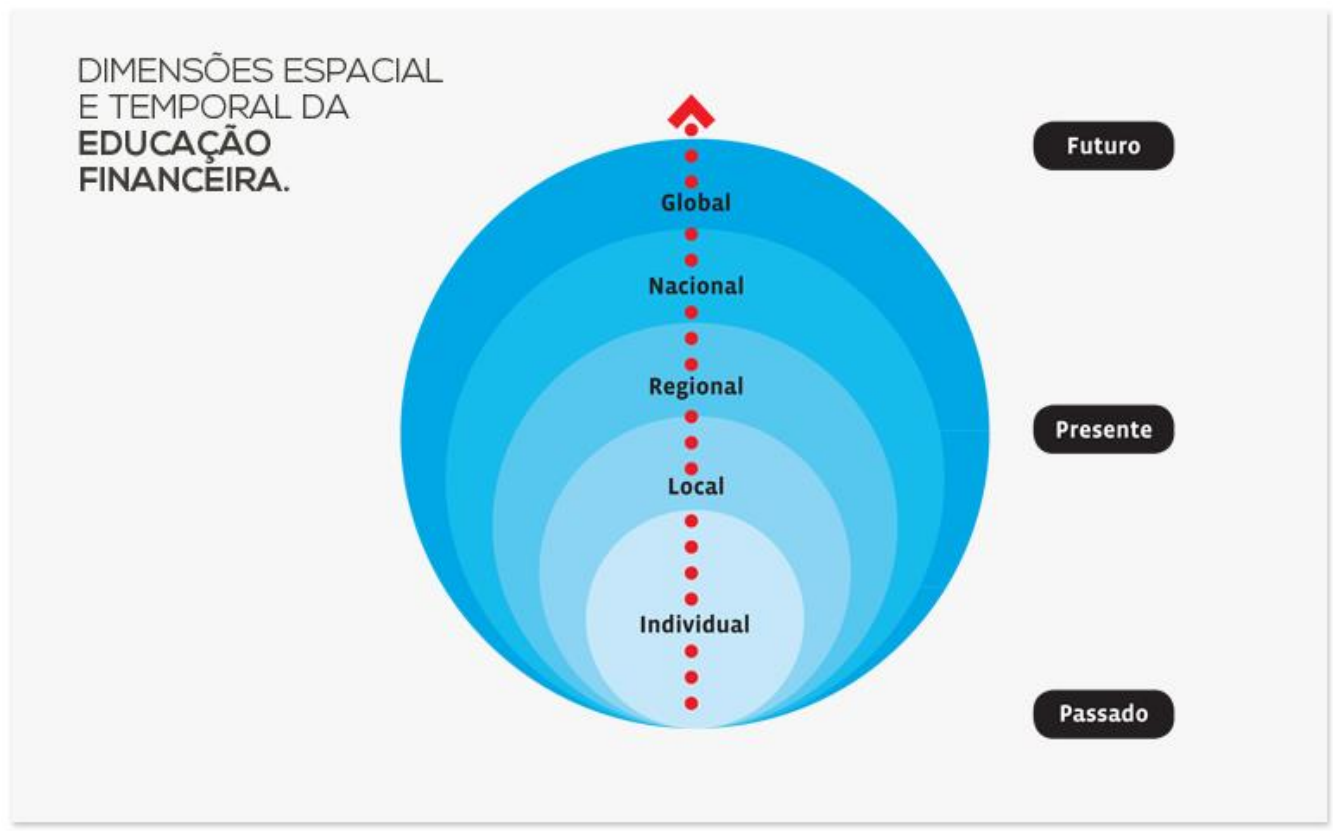

Figura 15 - Dimensões da Educação Financeira.

Fonte: BRASIL. Programa de Educação Financeira nas Escolas: Modelo Conceitual e Objetivos. 2016i.

\section{2}

\section{Comitê Nacional de Educação Financeira - CONEF}

O artigo $3^{\circ}$ do Decreto ${ }^{\circ} 7.397$ de 2010 constituiu o Comitê Nacional de Educação Financeira - CONEF, composto por um Diretor do Banco Central do Brasil, pelo Presidente da Comissão de Valores Mobiliários, pelo DiretorSuperintendente da Superintendência Nacional de Previdência Complementar, pelo Superintendente da Superintendência de Seguros Privados, pelos SecretáriosExecutivos do Ministério da Fazenda, do Ministério da Educação, do Ministério do Trabalho e Previdência Social e da Justiça. Além desses integrantes, o aludido diploma legal garantiu a participação de quatro representantes da sociedade civil $^{21}$

\footnotetext{
${ }^{21}$ Ressalte-se que o Decreto $\mathrm{n}^{\mathrm{o}} 8.584$ de 07 de dezembro de 2015 altera a redação original do Decreto $\mathrm{n}^{\circ} 7.397$ de 2010 e institui que o CONEF será integrado por até seis representantes da sociedade civil. A Deliberação $\mathrm{n}^{\circ} 15$, de 27 de agosto de 2014 estabeleceu que as entidades escolhidas para representar a sociedade civil no CONEF, no período de $1^{\circ}$ de janeiro de 2015 a 31 de dezembro de 2017, são: I - Associação Brasileira das Entidades dos Mercados Financeiro e de Capitais (Anbima); II - Bolsa de Valores, Mercadorias e Futuros (BM\&FBovespa); III Confederação Nacional das Empresas de Seguros Gerais, Previdência Privada e Vida, Saúde Suplementar e Capitalização (CNSeg); e IV - Federação Brasileira de Bancos (Febraban) (BRASIL, 2015).
} 
no Comitê, indicados nos termos estabelecidos pelo regimento interno do CONEF, que é apresentado na Figura 16 como elemento central da estrutura da ENEF (BRASIL, 2010a).

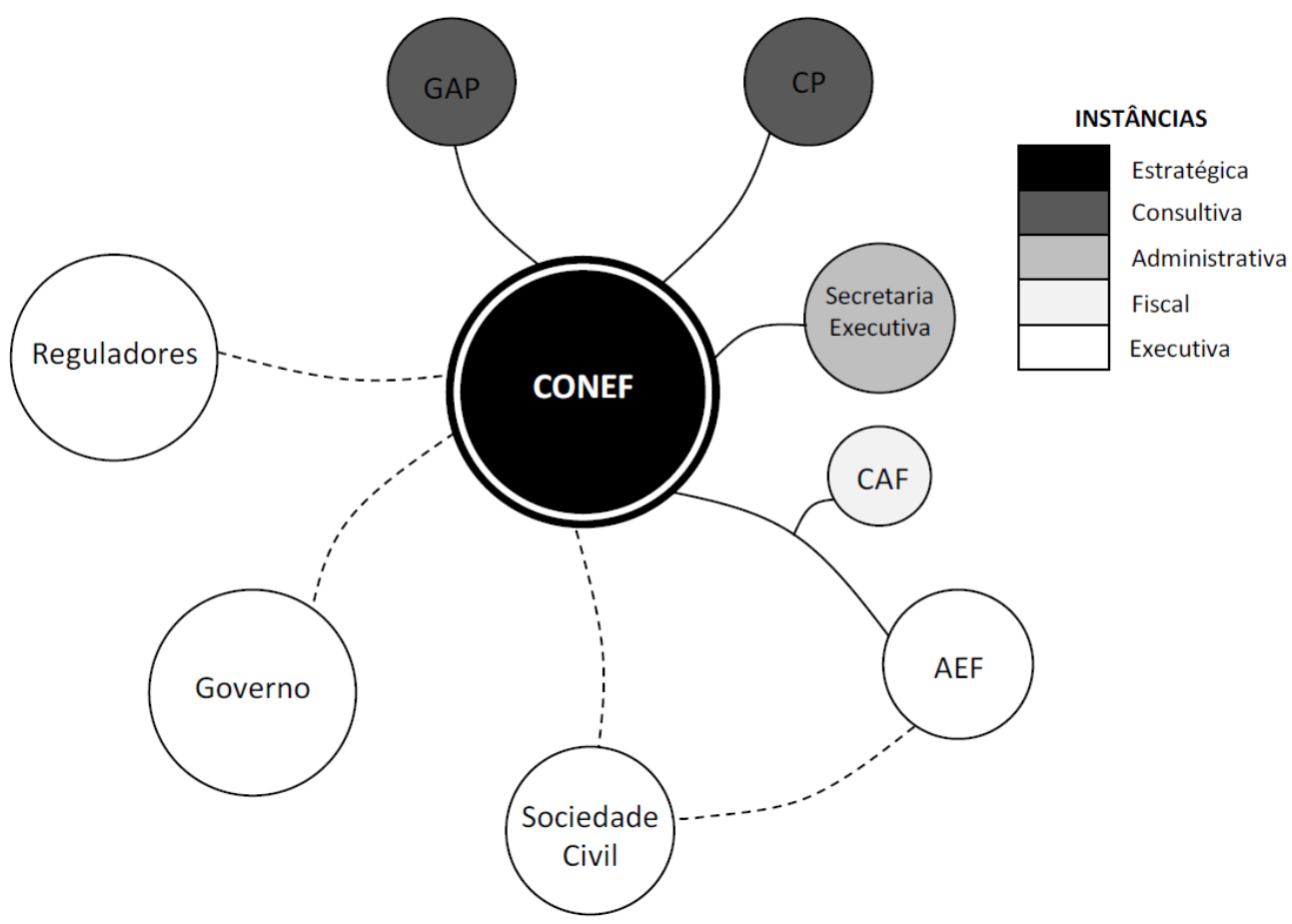

CONEF- Comitê Nacional de Educação Financeira

- Diretor do Banco Central do Brasil

- Presidente da Comissão de Valores Mobiliários

AEF - Associação de Educação Financeira do Brasil

Diretor-Superintendente da PREVIC

- BM\&FBOVESPA

Superintendente da SUSEP

- Secretário-executivo do MEC

- Secretário-executivo do MF

- Secretário-executivo do MPS

- Secretário-executivo do MJ

CNseg
FEBRABAN

Representantes da sociedade civil - 2011-2014 - • Susep

ANBIMA, BM\&FBOVESPA, FEBRABAN, e CNseg $\quad$ : Previc

GAP - Grupo de Apoio Pedagógico

- Ministério da Educação, como Presidente

AF - Comitê de Acompanhamento e Fiscalização

Banco Central

CVM

- Banco Centra

CVM

Programas Setoriais

Ministério da Fazenda

Reguladores

- Banco Centra

Susep

- Previc

- Conselho Nacional de Educação

- Instituições de ensino federais (até 5)

- CONSED

UNDIME

CP - Comissão Permanente

- 12 membros efetivos, representando cada participante do CONEF

Secretaria Executiva

- CVM

Susep

- Previc

Governo

- Ministério da Educação

Ministério da Fazenda

- Ministério da Justiça

- Ministério do Desenvolvimento Social

- Ministério da Previdência Social

- Depto. de Educação Financeira do Banco Centra

Sociedade Civil

- ANBIMA

- BM\&FBOVESPA

CNseg

- FEBRABAN

Figura 16 - Estrutura da ENEF.

Fonte: BANCO CENTRAL DO BRASIL. Brasil: implementando a Estratégia Nacional de Educação Financeira. 2016. 
O artigo $5^{\circ}$ do Decreto $n^{\circ} 7.397$ de 2010 ainda institui, no âmbito do Ministério da Fazenda, o Grupo de Apoio Pedagógico - GAP com o objetivo de assessorar o CONEF quanto aos aspectos pedagógicos relacionados com a educação financeira e previdenciária (BRASIL, 2010a).

Nas suas duas primeiras deliberações, o CONEF aprovou seu Regimento Interno e o Plano Diretor que consolida a Estratégia Nacional de Educação Financeira - ENEF (BRASIL, 2016b).

Os programas da ENEF são guiados pelo Plano Diretor e seus Anexos, documentos que materializam a atuação da Estratégia Nacional de Educação Financeira. As ações da ENEF são compostas pelos programas transversais e setoriais, coordenados de forma centralizada, mas executados de modo descentralizado (BRASIL, 2016c).

\section{3}

Programas Transversais da ENEF

São as ações de educação financeira da ENEF que, de acordo com o público beneficiário ou a temática financeira priorizada, não são de responsabilidade exclusiva de determinado órgão ou entidade. Seus objetivos demandam a conjugação de diversos temas como proteção, planejamento financeiro, poupança, investimento, crédito e defesa do consumidor (BRASIL, 2016d).

Os programas transversais são coordenados pela Associação de Educação Financeira do Brasil - AEF-Brasil, organização sem fins lucrativos, criada em 2011 e que contribui com a ENEF por meio do desenvolvimento de tecnologias sociais e educacionais que podem ser reaplicadas por qualquer pessoa ou organização interessada, dando assim a escala necessária ao tema educação financeira (BRASIL, 2016d).

Apresentaremos, a seguir, algum detalhamento sobre dois programas transversais da ENEF, a saber, o Programa de Educação Financeira de Adultos e o Programa Educação Financeira nas Escolas. 


\subsection{1}

\section{Programa de Educação Financeira de Adultos}

Segundo a Associação de Educação Financeira do Brasil - AEF-Brasil (2016a), a educação financeira da população adulta se constitui um grande desafio. Os adultos, na maioria das vezes, não participam mais de processos de educação formais e têm visões já construídas e, em muitos casos, arraigadas. O programa almeja não só o desenvolvimento de tecnologias que resultem em conhecimento sobre educação financeira para esse público-alvo, mas fundamentalmente que tornem suas escolhas balizadas em atitudes e comportamentos financeiros saudáveis.

Ainda de acordo com a AEF-Brasil (2016a), o objetivo do programa é a construção de duas tecnologias sociais e educacionais: uma para aposentados com renda até dois salários mínimos, os quais, com base nos dados de 2010 do Instituto Nacional de Seguridade Social - INSS são uma população grande tomadora de crédito, levando-a em alguns casos ao superendividamento; e outra para mulheres beneficiárias do Programa Bolsa Família, que, segundo dados de 2010 do Cadastro Único do Ministério do Desenvolvimento Social - MDS, são 92,5\% dos responsáveis pela retirada do benefício.

É relevante destacar que a pretensão do programa é promover a educação financeira para grupos que, segundo a Pesquisa sobre Educação Financeira Global da S\&P tratada no capítulo anterior, considerando gênero, faixa etária e renda, apresentam vulnerabilidades, uma vez tendo sido identificados como possuidores de baixo nível de letramento financeiro em todo o mundo e especialmente no Brasil.

O detalhamento desse projeto nacional foge ao escopo desse trabalho, mas apresenta grande potencial de desenvolvimento de um trabalho com Matemática Financeira Básica na Educação de Jovens e Adultos (EJA) em ambiente escolar. 


\subsection{2}

\section{Programa Educação Financeira nas Escolas}

Conforme divulgado pela Associação de Educação Financeira do Brasil AEF-Brasil (2016b), o Programa de Educação Financeira para o público-alvo de crianças e jovens foi concebido por dois projetos, um voltado para o Ensino Fundamental e outro para o Ensino Médio. Eles contam com um projeto pedagógico e dois conjuntos de livros, cada qual para a etapa específica, ambos segmentados por níveis de ensino que oferecem ao aluno e ao professor atividades educativas que permitem a inserção do tema na vida escolar.

De acordo com a AEF-Brasil, o modelo pedagógico e o conteúdo dos dois projetos foram concebidos tendo como base o documento "Orientação para Educação Financeira nas Escolas", construído ao longo de um ano com a participação do Ministério da Educação - MEC, da União Nacional dos Dirigentes Municipais de Educação - UNDIME, do Conselho Nacional de Secretários de Educação - CONSED e diversas outras instituições educacionais e financeiras, tendo o trabalho sido coordenado pela Comissão de Valores Mobiliários - CVM. O aludido documento balizou a produção dos materiais didáticos citados anteriormente, voltados ao Ensino Fundamental e ao Ensino Médio.

A intenção do Programa é que tanto o modelo pedagógico quanto os conteúdos financeiros possibilitem ao aluno se colocar como protagonista de sua história de vida, dando a ele condições de planejar e fazer acontecer o futuro que deseja para si, em conexão com o grupo familiar e social a que pertence.

O Programa Educação Financeira nas Escolas se iniciou no Ensino Médio, tendo sido aplicado, durante o período de 2010 a 2011, um projeto piloto em 891 escolas públicas de Ensino Médio de seis unidades de federação (AEF-BRASIL, 2016c).

Consoante a AEF-Brasil (2016c), posteriormente, a tecnologia foi dada como pronta, de acordo com um método de avaliação rigorosa do Banco Mundial, para disseminação em formato aberto (download em página na internet, mediante cadastro de login e senha) ou formato assistido (livros impressos para alunos e 
professores de instituições cadastradas) nas escolas de Ensino Médio, conforme pode ser observado na Figura 17.

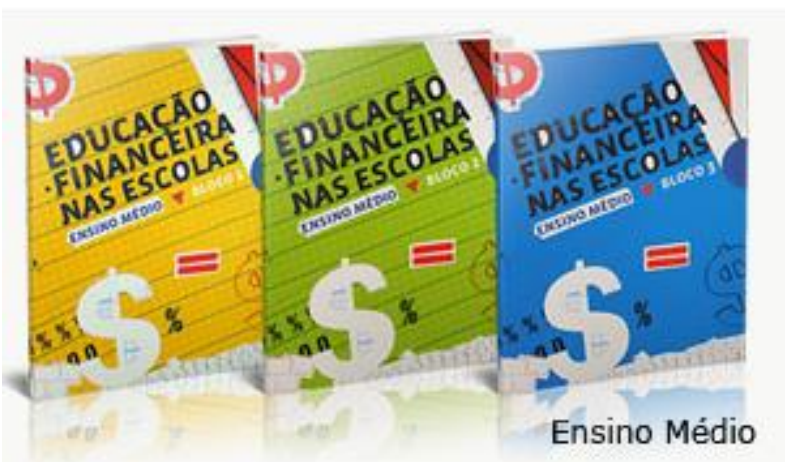

Figura 17 - Coleção de livros do Programa de Educação Financeira nas Escolas: Ensino Médio.

Fonte: ASSOCIAÇÃO DE EDUCAÇÃO FINANCEIRA DO BRASIL - AEF-Brasil, Educação financeira nas escolas. 2016b.

Em relação ao Ensino Fundamental, o objetivo do projeto é contribuir com as principais questões da escola na atualidade, contribuindo para a construção da educação financeira desde os anos iniciais desse período escolar (AEF-BRASIL, 2016d).

Além de colaborar para a educação financeira, a iniciativa também foi pensada para proporcionar a melhoria de desempenho dos alunos em língua portuguesa e matemática (AEF-BRASIL, 2016d).

Segundo a AEF-Brasil (2016d), o conjunto de nove livros, sendo um para cada ano do Ensino Fundamental, foi desenvolvido com base no conceito de ciclos e integrando os conteúdos financeiros aos conteúdos sociais, priorizando situações reais e cotidianas da faixa etária dos alunos. Os livros foram finalizados em outubro de 2014 com o apoio da BM\&FBOVESPA e um projeto piloto foi aplicado em 200 escolas dos municípios de Joinville (SC) e de Manaus (AM) durante o ano de 2015, envolvendo 20.000 alunos e 2.000 professores das redes públicas desses municípios. Em 2016, o projeto se encontra em fase de avaliação conduzida pelo Banco Mundial e, após esse processo, a tecnologia educacional estará pronta para disseminação em escala nacional.

Apesar da avaliação do projeto para o Ensino Fundamental ainda estar em curso, o material didático, tanto do aluno como do professor, encontra-se $\begin{array}{lllll}\text { disponível } & \text { para } & \text { download } & \text { no }\end{array}$ http://www.edufinanceiranaescola.gov.br/ensino-fundamental mediante cadastro 
de login e senha. A Figura 18 apresenta parte do material didático usado no projeto.

LIVRO ALUNO

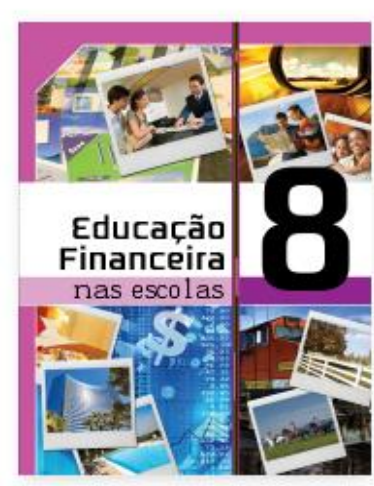

LIVRO

PROFESSOR

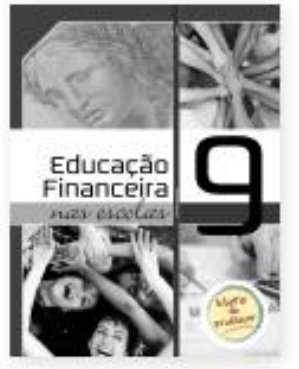

Figura 18 - Livros do professor e do aluno para o $8^{\circ}$ e $9^{\circ}$ anos de escolaridade do Programa de Educação Financeira nas Escolas: Ensino Fundamental.

Fonte: BRASIL. Programa de Educação Financeira nas Escolas: Materiais. 2016k.

A proposta do material é que os livros possam ser utilizados por professores de qualquer matéria, de modo que o professor possa enriquecê-los com atividades específicas de sua disciplina.

Considerando que o material didático para o Ensino Fundamental se encontra em fase de avaliação durante o ano de 2016, a análise sobre a abordagem dos conteúdos de Matemática Financeira contidos nesse material não serão objeto de nossa apreciação nesse trabalho.

Entretanto, consideramos que a análise desse material tem grande potencial para a realização de trabalhos futuros sobre a abordagem de Matemática Financeira para o Ensino Fundamental.

\section{4}

Mapeamento Nacional de Iniciativas de Educação Financeira 
O primeiro Mapeamento Nacional das Iniciativas de Educação Financeira foi um projeto da Estratégia Nacional de Educação Financeira - ENEF, coordenado pela Associação de Educação Financeira do Brasil - AEF-Brasil, com o objetivo de conhecer com maior abrangência e profundidade o cenário da educação financeira no Brasil (BRASIL, 2016e).

Em 2009, um levantamento preliminar de iniciativas de educação financeira no país havia identificado 64 iniciativas. Em 2013, o primeiro Mapeamento Nacional das Iniciativas de Educação Financeira identificou 803 ações em diferentes regiões brasileiras. O levantamento foi realizado por meio de cadastro no sítio Vida e Dinheiro (http://www.vidaedinheiro.gov.br), em que pessoas físicas e jurídicas responderam voluntariamente ao questionário disponibilizado. Das 803 iniciativas mapeadas, 317 delas foram completamente cadastradas (BRASIL, 2016e).

Apesar de não se tratar de uma pesquisa censitária e não ter havido verificação in loco, a partir dos dados cadastrados temos um importante panorama da educação brasileira.

O Mapa da Educação Financeira no Brasil foi apresentado em dois documentos: a) dados estatísticos sobre quem faz a EF no Brasil, o que faz e como faz; e b) documento analítico sobre os dados levantados, apontando avanços e oportunidades para qualificação e promoção do tema (BRASIL, 2016e). Os dados apresentados em ambos os documentos podem ser fonte de importantes reflexões sobre os desafios e as oportunidades da área no país.

Um relevante aspecto observado no documento que trata dos dados estatísticos é que adultos e jovens integrantes do Ensino Médio ou do Ensino Superior são os mais beneficiados por essas iniciativas de educação financeira.

Além disso, observamos que $31 \%$ das iniciativas cadastradas têm em comum o objetivo de sensibilizar crianças e adolescentes para o tema (BRASIL, 2016e).

\section{5}

\section{Base Nacional Comum Curricular}


A necessidade de criação de uma Base Nacional Comum Curricular aparece na nossa Constituição Federal de 1988, no artigo 210, o qual estabelece que "serão fixados conteúdos mínimos para o Ensino Fundamental, de maneira a assegurar formação básica comum e respeito aos valores culturais e artísticos, nacionais e regionais" (BRASIL, 1988).

Anos depois, ela também foi prescrita na Lei de Diretrizes e Bases da Educação Nacional - LDBEN, em seu artigo 26, o qual determina que "os currículos da educação infantil, do Ensino Fundamental e do Ensino Médio devem ter base nacional comum, a ser complementada, em cada sistema de ensino e em cada estabelecimento escolar, por uma parte diversificada, exigida pelas características regionais e locais da sociedade, da cultura, da economia e dos educandos" (BRASIL, 1996).

A Base Nacional Comum Curricular definirá, portanto, a parte principal dos currículos em âmbito nacional, por determinação do Plano Nacional de Educação - PNE, o qual tem vigência de dez anos e foi aprovado pela Lei $n^{\circ}$ 13.005, de 25 de junho de 2014. O PNE tem 20 metas para a melhoria da qualidade da Educação Básica e quatro delas falam sobre a Base Nacional Comum Curricular (BRASIL, 2016h).

Para elaboração da Base Nacional Comum Curricular foi garantida participação da sociedade por meio de consulta pública para contribuições em seu sítio oficial, as quais foram coletadas até 15 de março de 2016. Os dados disponíveis indicam que foram apresentadas mais de 12 milhões de contribuições ao documento preliminar, metade delas produzidas pelas 45 mil escolas que se cadastraram no portal. Ao todo, mais de 300 mil cadastros foram registrados no sítio. Dentre os cadastrados, 207 mil professores (BRASIL, 2016g).

O Ministério da Educação - MEC afirma que a educação financeira figura entre os temas da atualidade sugeridos para compor a Base Nacional Comum Curricular - BNCC. A Representante da Secretaria de Educação Básica do Ministério da Educação acrescenta que a educação financeira está incluída no documento preliminar da Base Nacional Comum Curricular como tema integrador denominado consumo e educação financeira. Ou seja, é trabalhado de forma transversal nas disciplinas curriculares da Educação Básica (BRASIL, 2016j). 
Segundo o calendário disponibilizado no sítio oficial, a versão final do documento somente estará disponível a partir de junho de 2016.

\section{6}

\section{Avaliando o cenário nacional}

A Estratégia Nacional de Educação Financeira - ENEF já pode ser considerada um grande avanço para o Brasil, no sentido de priorizar um tema essencial para a formação do cidadão. O reconhecimento da sociedade quanto à necessidade de inclusão de temas afetos à educação financeira na Base Nacional Curricular Comum demonstra que os brasileiros entendem esse tópico como relevante para a formação do estudante da Educação Básica.

Entretanto, já em 2016, acreditamos que ainda há um longo caminho para que a difusão de todas as ideias e materiais pedagógicos construídos no âmbito do Programa de Educação Financeira nas Escolas alcance as salas de aula das escolas públicas de todo o país.

Os professores de matemática, por serem os responsáveis pela introdução de conceitos de Matemática Financeira aos alunos no âmbito escolar, apresentam também uma grande responsabilidade na iniciação dos estudantes em educação financeira. O conhecimento de Matemática Financeira é uma ferramenta relevante para o letramento financeiro futuro do indivíduo e, considerando a resistência que muitos educandos demonstram à aprendizagem de matemática, o desafio do professor torna-se ainda maior. 


\section{Matemática Financeira no Ensino Fundamental}

Não é exagero afirmar que a educação financeira é um elemento integrante da formação cidadã de cada pessoa. Vejamos o que afirma D’Ambrosio sobre a conexão entre cidadania e matemática:

Cidadania tem tudo a ver com a capacidade de lidar com situações novas. Lida-se com situações conhecidas e rotineiras a partir de regras que são memorizadas e obedecidas. Mas o grande desafio está em tomar decisões sobre situações imprevistas e inesperadas, que hoje são cada vez mais frequentes. A tomada de decisões exige criatividade e ética. A matemática é um instrumento importantíssimo para a tomada de decisões, pois apela para a criatividade. Ao mesmo tempo, a matemática fornece os instrumentos necessários para uma avaliação das consequências da decisão escolhida. A essência do comportamento ético resulta do conhecimento das consequências das decisões que tomamos (D'AMBROSIO, 2002).

Ainda assim, entendemos que a educação financeira do cidadão não se reveste apenas de aspectos matemáticos. É inegável que as dimensões econômicas, psicológicas e comportamentais, dentre outras, interferem significativamente no letramento financeiro do sujeito. Entretanto, o conhecimento matemático fornecerá as ferramentas necessárias à tomada de decisões financeiras com a maior precisão possível, considerando o tempo, o dinheiro e as taxas envolvidas.

A atividade docente e os pressupostos pedagógicos são, portanto, determinantes para a educação financeira de cada um e, por conseguinte, para a construção desse aspecto da cidadania.

Nos subcapítulos a seguir apresentaremos nossas considerações sobre a atividade docente. Trataremos especificamente da contextualização e dos alicerces necessários ao letramento financeiro do educando. Esclarecemos que, no âmbito desta dissertação, tomaremos por referência os conceitos de letramento financeiro considerados básicos pelos autores da Pesquisa sobre Educação Financeira Global da S\&P. Conforme já mencionados anteriormente, esses conceitos são: a) habilidade numérica (aplicada ao uso da porcentagem no cálculo de juros); b) juros compostos; c) inflação e d) diversificação de riscos. 


\section{1}

\section{A importância da contextualização}

Ao se estabelecer uma relação entre uma situação dada envolvendo cálculos e sua representação, o raciocínio contextualizado favorece a articulação das variáveis em jogo e contribui para o processo de resolução do problema matemático envolvido.

O professor de matemática de Ensino Fundamental depara-se muitas vezes com situações em que os alunos questionam qual seria a "conta" que deve ser feita para se encontrar a solução de algum problema. Ou, ainda, encontra-se em situações nas quais os alunos conseguem identificar qual seria o cálculo adequado, mas por algum erro no algoritmo de resolução ou falta de atenção, chegam a respostas obviamente absurdas e sequer se dão conta do fato. Ou seja, para esses, desde que a "conta" adequada foi realizada, não haveria necessidade alguma de avaliação do resultado encontrado para o problema.

Para exemplificar tal questão, vejamos um fato apresentado por Carraher et al. (1988 apud MOYSÉS, 2012, p. 65), que compara um experimento em que um grupo de estudantes de $7^{\circ}$ ano do Ensino Fundamental e mestres de obras foram solicitados a realizar cálculos de proporções.

A primeira atividade que lhes foi solicitada consistia em, dada uma medida na planta, em uma determinada escala, e outra medida correspondente à parede real, descobrir qual era a escala utilizada. A segunda atividade consistia em medir uma parede no desenho e, com base na escala usada, determinar sua medida real, na construção. Foram utilizados quatro tipos de escalas: 1:100, 1:50, 1:40 e 1:33,3. Por exemplo: (1) se no desenho a parede mede $6 \mathrm{~cm}$ e na obra a parede mede 3 metros, qual a escala que está sendo usada? (2) se no desenho ele mede $7,5 \mathrm{~cm}$, quanto ele deverá medir na obra, em uma escala 1:50?

Os autores relatam que é evidente que o mestre de obras tem uma familiaridade com esse tipo de atividade, ausente no estudante. Enquanto o aluno aprende o algoritmo da proporção descolado da realidade $(\mathrm{a} / \mathrm{b}=\mathrm{c} / \mathrm{x})$, o mestre de obras é obrigado, por força da profissão, a dominar o cálculo das relações envolvidas em uma escala (ainda que na prática sejam utilizadas geralmente as de 1:100 ou de 1:50). 
Segundo Moysés (2012), os resultados dessa pesquisa demonstraram a superioridade dos mestres de obras em relação aos estudantes, quando solicitados a realizar cálculos de proporção em geral. Entretanto, o que mais chamou a atenção foi o fato de não haver respostas absurdas por parte dos mestres de obras. Mesmo no caso de escalas desconhecidas, como 1:33,3, as respostas foram encontradas mediante estimativas muito plausíveis. Os estudantes não só mostraram incapacidade para fazer uso sistemático do algoritmo da proporção aprendido naquele ano na escola, como também careceram de espírito crítico para perceber a falta de sensatez nas respostas dadas. Por exemplo, concluir que a parede deveria ter $3 \mathrm{~m}$ e $753 \mathrm{~cm}$ [sic] ou, em uma escala 1:100, fazer corresponder $3 \mathrm{~cm}$ a $33 \mathrm{~cm}$.

Os resultados do experimento relatado apenas confirmam uma situação com a qual deparamo-nos em nosso dia a dia profissional: a falta de sentido muitas vezes evidenciada pelos alunos nas respostas às questões apresentadas, demonstrando haver completa dissociação entre a realização da atividade e o sentido do que está ali proposto, além da falta de análise crítica dos resultados encontrados. Um mestre de obras, ainda que não saiba trabalhar com vírgulas ou desconheça o algoritmo da proporção, sabe avaliar se o valor encontrado é ou não razoável. A experiência profissional que eles possuem favorece a manutenção do sentido e crítica durante toda a operação mental que realizam, o que normalmente não ocorre com o estudante.

É evidente que um adulto, ainda que não tenha sido submetido à escolarização formal no passado, possui uma vivência e experiências indispensáveis à sua sobrevivência hoje, uma vez que um cidadão precisa compreender informações matemáticas, realizar registros matemáticos e estabelecer relações entre dados matemáticos e outras habilidades e conhecimentos, de acordo com o que sua realidade histórica e social exige.

Dessa forma, a tarefa árdua que se coloca diante do professor de matemática no Ensino Fundamental regular é justamente esta: fazer com que os algoritmos matemáticos e as sistematizações apreendidas pelos jovens estudantes tenham significado para eles. Os alunos devem ser orientados a submeter ao crivo da razão, de forma crítica, as respostas encontradas para os cálculos realizados. É importante que eles se deem conta que a matemática não está dissociada da 
realidade e que a sua compreensão é mais uma ferramenta para tomada de decisões.

Por exemplo, qual é o interesse, do ponto de vista do indivíduo e da sociedade, em concluir que os jovens brasileiros chegam aos 12 anos sabendo conjugar corretamente o verbo "sentar"? Talvez eles jamais tenham percebido o que significa, socialmente, estar sentado. E que importará saber se nessa idade eles são capazes de extrair a raiz quadrada de 12.764 ? Ou de somar 5/39 + 7/65? Qual a relação disso com a satisfação e a ampliação de seu potencial como indivíduos e de seu exercício pleno da cidadania? (D’AMBROSIO, 2012, p. 58).

Nesse momento, gostaríamos de deixar claro que nosso entendimento não é o de que a contextualização deve substituir as outras metodologias de ensino para todos os conceitos matemáticos que fazem parte do currículo escolar, mas que ela possa complementá-las e enriquecer a prática da sala de aula, na busca da excelência do processo de ensino-aprendizagem. Afinal, o aspecto abstrato da matemática é fundamental para o desenvolvimento da inteligência do estudante.

No entanto, em se tratando de Matemática Financeira, conteúdo que faz parte do nosso cotidiano com porcentagens, juros, descontos, estatísticas, inflação etc., acreditamos que a contextualização se configura como estratégia metodológica de ensino-aprendizagem bastante eficaz.

\section{2}

\section{Habilidade Numérica}

No Brasil, o Ensino Fundamental obrigatório, com duração de nove anos, inicia-se aos seis anos de idade. Isso significa que os alunos chegam ao segundo segmento do Ensino Fundamental, que é o período compreendido entre o $6^{\circ}$ e o $9^{\circ}$ ano, com a idade de 11 anos, em regra.

Pela nossa experiência, verificamos que os professores de matemática que ministram aulas para o segundo segmento do Ensino Fundamental reconhecem que o nível de maturidade para a aquisição dos conhecimentos matemáticos mais abstratos nessa etapa é realmente baixo.

Talvez por essa razão, observamos que os conteúdos propostos nos livros didáticos de matemática de sexto ano de escolaridade reapresentam assuntos que 
já foram estudados pelos alunos em anos anteriores, fazendo com que esse ano seja considerado, em matemática, uma revisão abrangente de temas.

Considerando que os alunos que alcançaram esse segmento de ensino já conhecem (ou deveriam conhecer) os algoritmos necessários aos cálculos que envolvam as quatro operações fundamentais, frações e números decimais, o sexto ano do Ensino Fundamental é um excelente momento para que sejam trabalhadas as situações-problema de aplicações desses conceitos, conjugados ao cálculo mental aproximado, com base em estimativas.

Nesse momento, é necessário que o aluno seja constantemente desafiado a fazer estimativas, a pensar sobre a ordem de grandeza da resposta fornecida a determinado problema, a efetuar uma resolução mental, ainda que preliminar. A atividade de encontrar a "conta" certa para determinada questão, utilizar o algoritmo de resolução mecanicamente e encontrar a resposta "certa" dessa conta não demonstra que os objetivos foram alcançados. Na verdade, as "contas" realizadas não passam de ferramentas utilizadas para se chegar a um resultado preciso. Algo que uma calculadora ou computador podem fazer em uma velocidade muito maior que a nossa. Queremos dizer com isso que a habilidade numérica escrita não pode ser considerada um fim em si mesma.

Neste sentido, vale destacar que os Parâmetros Curriculares Nacionais para o ensino de matemática nas primeiras séries do Ensino Fundamental destacam a importância da capacidade em efetuar estimativas na formação matemática do educando:

Grande parte do cálculo realizado fora da escola é feito a partir de procedimentos mentais, que nem sempre são levados em conta no trabalho escolar. Nas situações práticas, frequentemente, não se dispõe de lápis e papel, tampouco é necessário, pois a maioria das respostas não precisa ser exata, basta uma aproximação. Existem ainda as balanças e as calculadoras que informam resultados com precisão. Por essas razões, uma das finalidades atuais do ensino do cálculo consiste em fazer com que os alunos desenvolvam e sistematizem procedimentos de cálculo por estimativa e estratégias de verificação e controle de resultados. Para atender a esse objetivo, é primordial que aprendam a reconhecer se certos resultados relacionados a contagens, medidas, operações são ou não razoáveis em determinadas situações. A estimativa constrói-se juntamente com o sentido numérico e com o significado das operações e muito auxilia no desenvolvimento da capacidade de tomar decisões (BRASIL, 1997, grifos nossos). 
Abaixo sugerimos alguns exemplos de atividades que poderiam ser utilizadas com alunos do $6^{\circ}$ ano do Ensino Fundamental, na faixa de 11 anos de idade, com o objetivo de estimular o desenvolvimento da capacidade em fazer estimativas.

1. Um teatro possui 98 ingressos de plateia disponíveis para a sessão de quinta-feira de um espetáculo. $\mathrm{O}$ valor de cada ingresso desse tipo é $\mathrm{R} \$$ 41,00. Encontre uma estimativa para o valor arrecadado, se todos os ingressos forem vendidos. Explique o raciocínio utilizado para o resultado encontrado.

2. Para fazer um almoço de domingo, foram comprados no supermercado 1 $\mathrm{kg}$ de batatas por $\mathrm{R} \$ 3,99,1 \mathrm{~kg}$ de tomates por $\mathrm{R} \$ 5,99,1 \mathrm{~kg}$ de frango por 11,99 e $1 \mathrm{~kg}$ de arroz por 2,99. Utilizando apenas cálculos mentais, determine quanto foi gasto aproximadamente nessa compra. Explique o raciocínio utilizado para o resultado encontrado.

3. Uma empresa obteve lucro de $\mathrm{R} \$ 1.001 .000,00$ em determinado mês e deseja dividi-lo igualmente entre seus 999 funcionários. É correto dizer que cada funcionário receberá aproximadamente $\mathrm{R} \$ 10.000,00$ ? Justifique sua resposta sem efetuar cálculos escritos.

As questões que propusemos possuem o objetivo de estimular o raciocínio, habilidade mental e análise crítica por parte dos alunos.

A correção das questões poderia ser feita em forma de construção coletiva, com a participação do professor e dos alunos, em que seriam dadas oportunidades para que os discentes expusessem sua linha de pensamento, mesmo no caso daqueles que inicialmente apresentassem respostas absurdas.

O trabalho com estimativas exige a adoção de estratégias, que, apesar de subjetivas, requerem desenvolvimento, aperfeiçoamento e sistematização. Cabe ao professor de matemática estimular o desenvolvimento dessas habilidades em seus alunos, valorizando as análises, interpretações, justificativas e construções.

Em nossa trajetória como docente, buscamos compreender o "erro" do aluno como oportunidade de descoberta, avaliando qual foi sua linha de pensamento e respectiva conclusão. Nossa experiência demonstra que é necessário 
seguir o caminho dele, para que juntos possamos encontrar um resultado que tenha significado para ele. Quando o professor estabelece o seu caminho e as suas conclusões para os alunos, está entregando um resultado "pronto" que, na maioria das vezes, não apresenta significado algum aos discentes.

\section{3}

\section{Porcentagem}

A introdução ao estudo de porcentagem com os alunos de Ensino Fundamental apresenta um grande número de fontes de pesquisa e consulta para a ação docente. Os jornais diários e as revistas de circulação semanal, em suas versões impressas ou virtuais, estão repletos de assuntos que estão presentes no cotidiano de todas as pessoas. Concordamos com Sá (2011), o qual defende que um estudo sobre porcentagens pode e deve ser iniciado de forma provocativa e contextualizada a partir de um texto, gráfico ou manchete de um desses meios jornalísticos.

Normalmente, o professor de matemática inicia a sistematização do estudo de porcentagem a partir das frações centesimais e dessa forma o aluno compreende que $100 \%$ representam um inteiro.

A partir daí verificamos que a compreensão dos alunos acerca de outros percentuais como, por exemplo, $50 \%$ ou $25 \%$ sendo relacionados a "50 em 100 " ou " 25 em 100" é bastante ampla e intuitiva.

Entretanto, nossa experiência em sala de aula demonstra que o entendimento dos alunos quanto às porcentagens relacionadas a razões não centesimais torna-se um grande desafio para o professor. Reconhecer, por exemplo, que 17 em 68 representam $25 \%$ não é um raciocínio tão intuitivo para a maioria dos alunos.

Os livros didáticos normalmente apresentam o seguinte algoritmo para determinação da taxa percentual, na situação acima:

$$
\frac{17}{68}=0,25=\frac{25}{100}=25 \% \text {. }
$$

Uma das razões pela qual o aluno oferece resistência a esse tipo de resolução reside em um grande entrave, reconhecidamente percebido pelos 
professores de matemática do Ensino Fundamental: grande dificuldade do estudante quanto à utilização do algoritmo da divisão, principalmente quando nesse cálculo estão envolvidos os números decimais.

Evidente que seria possível que o professor permitisse nesse momento a utilização da calculadora para realização desse algoritmo, eliminando assim essa barreira à resolução da questão.

Entretanto, pela nossa experiência, entendemos que há outro motivo a ser considerado para a dificuldade do educando. Ele não vê significado nesse algoritmo de determinação da taxa percentual e o encara como uma "fórmula" que deve ser utilizada. Essa falta de significado encontra raízes, principalmente, na incapacidade do aluno em relacionar grandezas proporcionalmente, já que ele usualmente compreenderia que 68 representam $100 \%$, mas apresenta dificuldade em constatar que 17 são $25 \%$ do total.

O estudo de razões, proporções e regra de três, que geralmente ocorre no $7^{\circ}$ ano de escolaridade, constitui um campo fértil para que o professor explore com seus alunos as inúmeras situações-problema que podem ser modeladas a partir desses conceitos, solidificando as bases necessárias ao entendimento do significado de porcentagem.

Concordamos com as ideias de D'Ambrosio, que relata:

Muitos perguntam: mas, então, deve-se deixar de lado o ensino de frações? Não. Conceituadas como razão de duas grandezas, elas são muito importantes. Mas o objeto fração, com o qual se realizam operações, tem nenhuma importância. Recomenda-se muita importância a razões e proporções, que infelizmente têm sido ofuscadas pelas operações com frações. E, portanto, muita importância para a regra de três, que com a utilização de uma calculadora, tem enormes possibilidades de ajudar na solução e análise de situações reais. Isso vai muito além da resolução de problemas. O que queremos é desenvolver a capacidade de lidar com situações novas, que dão origem a problemas. A formulação de problemas pelos alunos, a partir de uma situação nova, é muitíssimo mais importante que a resolução de problemas dados pelo professor (D’AMBROSIO, 2002, grifos nossos).

Dessa forma, a mesma situação citada anteriormente, em que se deseja encontrar o percentual que representa 17 em 68, poderia ser solucionada por um aluno do $7^{\circ}$ ano do Ensino Fundamental, na faixa de 12 anos de idade, utilizando a seguinte regra de três simples, conforme Quadro 1: 
Quadro 1 - Resolução de questão de porcentagem por regra de três simples.

\begin{tabular}{|c|c|}
\hline Quantidade & Porcentagem (\%) \\
\hline \multicolumn{1}{|c|}{68} & 100 \\
\hline 17 & $x$ \\
\hline $\begin{array}{l}68 \cdot x=100 \cdot 17 \\
x=\frac{1700}{68} \\
x=25\end{array}$ \\
\hline
\end{tabular}

Fonte: Elaborada pela autora.

A resolução proposta acima, ainda que haja a barreira da divisão já mencionada anteriormente (e que pode ser eliminada com auxílio da calculadora), normalmente faz mais sentido para o estudante que apreendeu a ideia de proporcionalidade, além de relacionar os conteúdos já estudados.

É importante que o aluno perceba não só a relação daquilo que está estudando com o seu dia a dia, como também note que existe relação entre os conceitos matemáticos entre si, quebrando o paradigma de uma matemática fragmentada.

Nosso entendimento é o de que o professor de matemática do Ensino Fundamental deve trabalhar com situações-problema envolvendo porcentagens que explorem o raciocínio dos alunos e a efetiva aprendizagem dos conceitos com significado. Não é necessário esperar o ingresso dos estudantes no Ensino Médio, no qual já possuem mais maturidade para assimilação de alguns conceitos matemáticos, para que a Matemática Financeira seja trabalhada.

O cálculo de porcentagens por proporcionalidade, aliado à capacidade de efetuar estimativas, permitiria que alunos do Ensino Fundamental resolvessem, por exemplo, questões que foram objeto de avaliação no Exame Nacional do Ensino Médio (Enem) ${ }^{22}$, na área de Matemática e suas Tecnologias.

\footnotetext{
${ }^{22}$ O Exame Nacional do Ensino Médio (Enem) é uma prova realizada pelo Ministério da Educação do Brasil, criada em 1998. Ela é utilizada para avaliar a qualidade do ensino médio no país. Seu resultado serve para acesso ao ensino superior em universidades públicas brasileiras, através do Sistema de Seleção Unificada (SiSU), assim como em algumas universidades públicas portuguesas.
} 
Quadro 2 - Questão do Exame Nacional do Ensino Médio (2015).

(Enem 2015) Uma pesquisa recente aponta que 8 em cada 10 homens brasileiros dizem cuidar de sua beleza, não apenas de sua higiene pessoal.

CAETANO, M.; SOEIRO, R.; DAVINO, R. Cosméticos.

Superinteressante, n. 304, maio 2012 (adaptado).

Outra maneira de representar esse resultado é exibindo o valor percentual dos homens brasileiros que dizem cuidar de sua beleza.

Qual é o valor percentual que faz essa representação?

A $80 \%$

B $8 \%$

C $0,8 \%$

D $0,08 \%$

E $0,008 \%$

Fonte: $\quad$ Enem $2015 . \quad$ Disponível em:

$<$ http://download.inep.gov.br/educacao_basica/enem/provas/2015/CAD_ENEM_2015_2a

APLICACAO_DIA_02_05_AMARELO.pdf>.

No Quadro 2 temos o exemplo de uma questão que poderia ser facilmente resolvida por um aluno do $7^{\circ}$ ano do Ensino Fundamental, na faixa de 12 anos de idade, sem nenhum cálculo escrito. $\mathrm{O}$ avaliado que possui o conceito básico de porcentagem, ao efetuar uma estimativa, já excluiria quatro das cinco opções de resposta apresentadas para a questão, as quais apresentam distância significativa daquela que atende corretamente ao comando.

A questão apresentada no Quadro 3 também poderia ser trabalhada com uma turma de $7^{\circ}$ ano de Ensino Fundamental, como passaremos a constatar. 
Quadro 3 - Questão do Exame Nacional do Ensino Médio (2014).

(Enem 2014) O Brasil é um país com uma vantagem econômica clara no terreno dos recursos naturais, dispondo de uma das maiores áreas com vocação agrícola do mundo. Especialistas calculam que, dos 853 milhões de hectares do país, as cidades, as reservas indígenas e as áreas de preservação, incluindo florestas e mananciais, cubram por volta de 470 milhões de hectares. Aproximadamente 280 milhões se destinam à agropecuária, 200 milhões para pastagens e 80 milhões para a agricultura, somadas as lavouras anuais e as perenes, como o café e a fruticultura.

FORTES, G. Recuperação de pastagens é alternativa para ampliar cultivos.

Folha de S. Paulo, 30 out. 2011.

De acordo com os dados apresentados, o percentual correspondente à área utilizada para agricultura em relação à área do território brasileiro é mais próximo de

A $32,8 \%$

B $28,6 \%$

C $10,7 \%$

D $9,4 \%$

E $8 \%$

Fonte: $\quad$ Enem $2014 . \quad$ Disponível em: $<$ http://download.inep.gov.br/educacao_basica/enem/provas/2014/CAD_ENEM_2014_DI A_2_06_CINZA.pdf >.

Primeiramente, uma leitura interpretativa das informações fornecidas na questão permitiria compreender que o objetivo da mesma seria encontrar o percentual que 80 milhões representam em 853 milhões. O professor poderia estimular os alunos a pensar em estimativas, eliminando dessa forma três das cinco opções de resposta apresentadas, considerando que 80 milhões em 853 milhões representam um percentual inferior a $10 \%$.

Além disso, seria bastante interessante explorar a ideia de proporcionalidade nesse caso, uma vez que não é necessário pensar efetivamente em "80 milhões em 853 milhões", pois "80 em 853" representa a mesma razão proporcionalmente. Observamos que os alunos costumam apresentar dificuldade em trabalhar com números relativamente grandes e diante deles geralmente surge um bloqueio que por vezes impede a resolução de problemas bastante simples.

Uma regra de três poderia finalizar a resolução da questão: 
Quadro 4 - Resolução de questão do Enem 2014.

\begin{tabular}{|c|c|}
\hline Área (milhões de hectares) & Porcentagem (\%) \\
\hline 853 & 100 \\
\hline \multicolumn{1}{|c|}{80} & $x$ \\
\hline $853 \cdot x=100 \cdot 80$ \\
$x=\frac{8000}{853}$ \\
$x \cong 9,4$
\end{tabular}

Fonte: Elaborada pela autora.

É interessante observar que, ainda que o aluno ainda não tenha desenvolvido a habilidade de efetuar cálculos envolvendo números decimais com precisão, ao encontrar a parte inteira da divisão realizada, isso já eliminaria a outra alternativa apresentada como resposta $(8 \%)$.

Em momentos de realização de provas como as do Enem, não é permitido que o avaliado faça uso de uma calculadora e essa estratégia de utilizar o raciocínio lógico na eliminação de respostas absurdas se configura bastante válida.

Retomando a uma das perguntas apresentadas pela Pesquisa sobre Educação Financeira Global da S\&P, a qual avalia a habilidade numérica (no contexto de cálculos de taxas de juros) e foi exibida no capítulo 2 (seção 2.2) desta dissertação, verificamos que a resposta correta à questão poderia ser encontrada por um aluno do $7^{\circ}$ ano do Ensino Fundamental, na faixa de 12 anos de idade. Afinal, encontrar 3\% de 100 e perceber que esse valor adicionado a 100 é inferior a 105 seria bastante trivial para um aluno que realmente entendeu o conceito de porcentagem.

Situações-problema que envolvem lucro, prejuízo, descontos e acréscimos também podem ser trabalhadas pelo professor de Ensino Fundamental. Além disso, estas são situações que trazem uma oportunidade para explorar a utilização da calculadora com os alunos.

Em nossa prática, observamos que, apesar da habilidade que os educandos da geração $\mathrm{Z}$ - os chamados nativos digitais - apresentam hoje em dia com os recursos tecnológicos, a utilização de uma calculadora simples muitas vezes não é 
uma tarefa fácil para eles. A correta utilização da calculadora pressupõe conhecimento de conceitos matemáticos básicos que, quando não observados, podem acarretar resultados completamente absurdos.

Para exemplificar, ao resolver com o auxílio de uma calculadora básica (não científica) a expressão numérica seguinte sem observar os critérios matemáticos de resolução, o estudante do $6^{\circ}$ ano do Ensino Fundamental certamente não encontraria o resultado correto.

$$
\begin{gathered}
20-10 \div 5+6 \times 1 \\
20-2+6
\end{gathered}
$$

Ao recorrer à calculadora básica e digitar a expressão numérica com as operações matemáticas na ordem em que aparecem, o aluno encontraria o resultado 8 como resposta. Os professores de matemática de Ensino Fundamental deparam-se constantemente com erros deste tipo na resolução de expressões numéricas pelos alunos:

$$
\begin{gathered}
20-10 \div 5+6 \times 1 \\
10 \div 5+6 \times 1 \\
2+6 \times 1
\end{gathered}
$$$$
8 \times 1
$$

8

Em nossa prática, verificamos que as situações que envolvem acréscimos e descontos sucessivos, utilizando a mesma taxa ou não, costumam provocar muitas dúvidas entre os alunos.

Vejamos o caso proposto no Quadro 5, o qual poderia ser trabalhado com um aluno do $7^{\circ}$ ano do Ensino Fundamental, na faixa de 12 anos de idade: 
Quadro 5 - Questão envolvendo acréscimo e desconto sucessivo.

Um lojista remarcou os preços de todos os seus produtos com acréscimo de $10 \%$ sobre o preço de etiqueta em cada um. Posteriormente, como estratégia para atrair clientes, resolveu fornecer um desconto de $10 \%$ no caso de pagamento em dinheiro. Uma pessoa resolve comprar nessa loja uma mercadoria que custa $\mathrm{R} \$$ 220,00 (depois da remarcação de preços) e paga em dinheiro. Se ela tivesse comprado a mercadoria antes da remarcação de preços teria gasto um valor maior, menor ou o mesmo valor de hoje?

Fonte: Elaborada pela autora.

Segundo nossa experiência, a maioria dos alunos de Ensino Fundamental responderia que o pagamento da mercadoria hoje seria o mesmo que aquele efetuado antes da remarcação de preços feita pelo lojista, uma vez que a mercadoria teve um aumento e posterior desconto de $10 \%$.

O conceito de proporção mais solidificado poderia fazer o aluno refletir que os percentuais de aumento e de desconto, embora sendo os mesmos, estão incidindo sobre valores diferentes e dessa forma não se anulariam, conforme inicialmente se supunha.

O Quadro 6 mostra uma resolução que poderia ser trabalhada com alunos do $7^{\mathrm{o}}$ ano do Ensino Fundamental, na faixa de 12 anos, por exemplo. 
Quadro 6 - Resolução da questão envolvendo acréscimo e desconto sucessivo.

Considerando que a mercadoria custa $\mathrm{R} \$ 220,00$ e será paga em dinheiro com desconto de $10 \%$, concluímos que o cliente pagará $90 \%$ do valor da mesma. Nesse caso, uma regra de três simples encontraria o preço a ser pago pelo cliente:

\begin{tabular}{|c|c|}
\hline Valor da mercadoria $(\mathrm{R} \$)$ & Percentual (\%) \\
\hline 220 & 100 \\
\hline$x$ & 90 \\
\hline $\begin{array}{l}100 \cdot x=90 \cdot 220 \\
100\end{array}$ \\
\hline$x=198$
\end{tabular}

Após a remarcação de preços, com aumento de $10 \%$, a mercadoria passou a custar $110 \%$ do seu preço original que correspondia inicialmente a $100 \%$. O valor original poderia ser encontrado com uma regra de três simples:

\begin{tabular}{|c|c|}
\hline Valor da mercadoria $(\mathrm{R} \$)$ & Percentual (\%) \\
\hline 220 & 110 \\
\hline$x$ & 100 \\
\hline $\begin{array}{l}110 \cdot x=100.220 \\
110\end{array}$ \\
\hline$x=200$
\end{tabular}

Verifica-se, portanto, que se o cliente tivesse comprado a mercadoria antes da remarcação de preços pagaria um valor maior do que aquele que pagou hoje.

Fonte: Elaborada pela autora.

É importante frisar que o verdadeiro entendimento dos conceitos de porcentagem e acréscimos constitui a base necessária à compreensão do conceito de juros, o qual certamente pode ser introduzido no Ensino Fundamental. 


\section{4}

Juros

O termo "juros" é amplamente utilizado no dia a dia. Daí decorre que o professor de matemática do Ensino Fundamental, ao iniciar o estudo desse assunto, certamente se deparará com alunos que já ouviram falar desse termo e já possuem algum conceito subjetivo para o mesmo.

Nesse momento, seria bastante produtivo que o professor disponibilizasse tempo para que os alunos manifestassem esses conceitos e permitisse amplo debate com a turma sobre assunto.

Deparamo-nos com uma situação bastante peculiar em sala de aula, quando em uma discussão introdutória sobre o assunto com uma turma de Educação de Jovens e Adultos de Ensino Fundamental, em uma escola pública situada em uma comunidade carente, um aluno imediatamente referiu-se a juros como "o que é cobrado pelo agiota quando pegamos dinheiro emprestado" e ainda mencionou que a taxa cobrada era de " $15 \%$ ao mês".

Não podemos desprezar esses saberes trazidos por nossos alunos quando nos dispomos à árdua tarefa de ensinar. Essa interação de vivências nos permite uma troca que consideramos enriquecedora para docentes e discentes no processo educacional. Referenciamo-nos em Freire (2013, p.92), o qual sabiamente relata que, em sua experiência, nunca foi possível separar em dois momentos o ensino dos conteúdos da formação ética dos educandos.

Passado esse momento de debate, o professor de Ensino Fundamental se vê diante de um dilema recorrente: é possível introduzir o estudo de juros compostos nesse segmento?

A ideia de trabalhar com problemas hipotéticos, completamente descolados da realidade, nos quais era proposto o uso de juros simples onde sabidamente se utiliza juros compostos, sempre nos incomodou. O nosso dia a dia demonstra que o conceito de juros sobre juros é o mais usual, tanto em nosso desfavor - como no caso de empréstimos -, como em nosso favor - no caso dos investimentos em geral.

Em nossa opinião, a fórmula de juros simples, usualmente trabalhada nos livros didáticos de Ensino Fundamental, apresenta importantes pontos críticos: 
funciona como fator desmotivador à aprendizagem do conteúdo ao apresentar um algoritmo de resolução que não incentiva o raciocínio por parte dos alunos, além de ir habituando os estudantes a pensarem em juros simples em situações que envolvam aplicações de juros compostos, quando sabemos que isso não corresponde à nossa realidade.

O Quadro 7 traz um exemplo de questão introdutória ao conceito de juros simples, resolvida em um livro didático de $7^{\circ}$ ano do Ensino Fundamental, na qual se pode verificar a ocorrência dos pontos críticos que relatamos.

Quadro 7 - Questão introdutória de juros simples retirada de livro didático.

Tomei emprestada de um amigo a quantia de $\mathrm{R} \$ 500,00$. Vou pagar daqui a 4 meses, tendo sido combinada a taxa de juros simples de 2,5\% ao mês. Quanto vou pagar de juros simples? Que valor total vou pagar ao final do empréstimo?

Solução:

Temos:

$\mathrm{C}=\mathrm{R} \$ 500,00$

$\mathrm{i}=2,5 \%$ ao mês $=0,025$ ao mês

$\mathrm{t}=4$ meses

Juros por mês $=500.0,025=12,50$

Total de juros $=500.0,025.4=50$

Um capital C, emprestado a uma taxa mensal i, durante $\mathrm{t}$ meses, gera um total de juros j, dado pela fórmula:

$$
J=C . i . t
$$

O total a ser pago ao final do empréstimo é denominado montante $(M)$ e corresponde ao capital mais o total de juros.

$$
M=C+j
$$

Assim, no exemplo:

$M=500+50=550$

Logo, vou pagar $\mathrm{R} \$ 50,00$ de juros e um montante de $\mathrm{R} \$ 550,00$ ao final do empréstimo.

Fonte: SILVEIRA, Ênio; MARQUES, Cláudio. Matemática: compreensão e prática. 2. ed. São Paulo: Moderna, 2013. 
Em nossa opinião, os professores em geral acreditam que o ensino de juros compostos no Ensino Médio é bastante facilitado pelos seguintes fatos: nesse segmento os alunos aprendem sobre progressões geométricas - o que favorece a compreensão do fator de correção, que compõe a fórmula do montante de juros compostos - e encontram-se mais habituados e com mais maturidade para lidar com as temidas "fórmulas".

No entanto, respondendo à pergunta formulada anteriormente, sobre a possibilidade da introdução ao estudo de juros compostos no Ensino Fundamental, acreditamos que isso é perfeitamente admissível.

Entendemos que o ensino contextualizado de juros compostos, aliado a taxas que correspondam à realidade, pressupõe operações com números decimais mais complexas e demoradas do que aquelas que poderiam ser exigidas no Ensino Fundamental.

Por essa razão, defendemos que esse conceito deve ser explorado nesse segmento com o auxílio de calculadoras e tabelas. A calculadora torna-se uma ferramenta bastante útil em sala de aula, uma vez que o objetivo da avaliação da aprendizagem do aluno nesse momento é a verificação da verdadeira compreensão sobre o correto cálculo dos juros nas situações apresentadas.

Além disso, seria interessante que o número de períodos de tempo não fosse elevado. Uma vez que o aluno compreenda a ideia de juros sobre juros mensais para um período de oito meses, por exemplo, seria bastante intuitivo utilizar a mesma ideia para um período de 12, 24 ou 36 meses.

Concordamos com o saudoso professor Morgado (2002) ${ }^{23}$ sobre o trabalho com juros simples no Ensino Fundamental:

[...] Uma coisa lastimável que se faz no ensino do Brasil é que no Ensino Fundamental [...] ensina-se juros simples. Isso é extremamente nocivo, porque, primeiro que isso realmente não serve para nada e segundo, isso cria no aluno a falsa ilusão de que ele aprendeu a fazer esses cálculos financeiros [...] Ao ensinar apenas juros simples, é melhor não ensinar [...] (MORGADO, 2002, grifos nossos)

\footnotetext{
${ }^{23}$ A aula original do professor Augusto César Morgado sobre o assunto Matemática Financeira ocorreu em julho de 2002 e foi retransmitida em 2010 no PAPMEM - Programa de Aperfeiçoamento para Professores do Ensino Médio promovido pelo Instituto de Matemática Pura e Aplicada - IMPA, em homenagem ao Professor, falecido em 2006.
} 
Em nossa opinião, uma vez que o aluno já tenha apreendido bem a ideia de porcentagem, fica fácil para o professor associá-la à taxa envolvida nas situações que envolvem juros, fazendo com que o aluno seja apresentado ao conceito de juros simples e compostos de forma simultânea.

Neste sentido, a questão mencionada anteriormente, que consta em um livro didático do Ensino Fundamental, poderia ser adaptada na forma como aparece no Quadro 8, tornando-a mais próxima de uma situação do cotidiano e sem se utilizar de fórmulas para sua resolução, além de abordar o conceito de juros compostos.

O professor poderia aproveitar para fazer um paralelo da situação, para o caso em que fossem utilizados juros simples, fazendo com o que o aluno perceba o crescimento da dívida nos dois casos.

A questão proposta poderia ser trabalhada com alunos do $7^{\circ}$ ou $8^{\circ}$ anos de escolaridade, na faixa de 12-13 anos de idade. 
Quadro 8 - Questão envolvendo juros compostos e simples.

Tomei emprestada com um amigo a quantia de $\mathrm{R} \$ 5.000,00$ por um período de 8 meses, tendo sido combinada a taxa de juros compostos de $5 \%$ ao mês. Que valor total vou pagar no final do empréstimo? Caso tivéssemos acordado o pagamento por juros simples, quanto eu pagaria?

Solução:

A tabela abaixo mostra a evolução da dívida ao longo dos meses, considerando juros compostos e juros simples. É bom observar que, no caso dos juros simples, eles incidem sempre sobre o valor inicial, enquanto que nos juros compostos temos a cobrança de juros sobre juros.

\begin{tabular}{|c|c|c|c|c|}
\hline Mês & $\begin{array}{c}\text { Juros compostos } \\
(\mathrm{R} \$)\end{array}$ & $\begin{array}{c}\text { Saldo devedor } \\
(\mathrm{R} \$)\end{array}$ & $\begin{array}{c}\text { Juros simples } \\
(\mathrm{R} \$)\end{array}$ & $\begin{array}{c}\text { Saldo devedor } \\
(\mathrm{R} \$)\end{array}$ \\
\hline 0 & 0,00 & $5.000,00$ & 0,00 & $5.000,00$ \\
\hline 1 & 250,00 & $5.250,00$ & 250,00 & $5.250,00$ \\
\hline 2 & 262,50 & $5.512,50$ & 250,00 & $5.500,00$ \\
\hline 3 & 275,63 & $5.788,13$ & 250,00 & $5.750,00$ \\
\hline 4 & 289,41 & $6.077,54$ & 250,00 & $6.000,00$ \\
\hline 5 & 303,88 & $6.381,42$ & 250,00 & $6.250,00$ \\
\hline 6 & 319,07 & $6.700,49$ & 250,00 & $6.500,00$ \\
\hline 7 & 335,02 & $7.035,51$ & 250,00 & $6.750,00$ \\
\hline 8 & 351,78 & $7.387,29$ & 250,00 & $7.000,00$ \\
\hline
\end{tabular}

Dessa forma, pagarei $\mathrm{R} \$ 7.387,29$ no prazo combinado. Caso tivéssemos acordado o pagamento por juros simples, pagaria $\mathrm{R} \$ 7.000,00$.

Fonte: Elaborada pela autora.

A questão proposta dessa forma, além de fazer uma comparação entre a utilização dos juros simples e dos juros compostos, torna perceptível ao estudante o "poder" dos juros sobre juros, uma vez que, verificando a evolução do saldo devedor mês a mês, o aluno já poderia refletir sobre a consequência para o montante dessa dívida ao final de 12, 24 ou 36 meses, por exemplo, se nenhum pagamento intermediário fosse feito. A tabela ressalta ainda o fato de que, com 
uma unidade de tempo de cobrança, nesse caso um mês, o valor a ser pago seria exatamente o mesmo nos dois casos.

Tratando especificamente deste último aspecto comentado, que é o fato de que, para uma unidade de período de tempo, os juros a serem cobrados são iguais, independente de serem simples ou compostos, sugerimos que a abordagem do assunto possa ser feita com uma situação-problema para um aluno do $7^{\circ}$ ou $8^{\circ}$ ano de escolaridade, na faixa de 12-13 anos de idade, conforme Quadro 9.

Quadro 9 - Questão envolvendo taxa de juros.

Uma loja oferece as seguintes opções de compra aos seus clientes:

- à vista, com $10 \%$ de desconto sobre o preço de tabela; ou

- com o acréscimo de $20 \%$ sobre o preço de tabela, em dois pagamentos iguais (o primeiro no ato da compra e o segundo um mês depois).

Um cliente resolveu comprar uma mercadoria, cujo preço de tabela é igual a $\mathrm{R} \$$ 100,00, utilizando a segunda opção de compra. Qual é a taxa de juros "embutida" que está sendo cobrada na segunda opção de compra?

Fonte: Elaborada pela autora.

De acordo com nossa experiência, o erro mais comum cometido pelos adolescentes (e até por muitos adultos) nesse tipo de situação é considerar que a taxa de juros cobrada por essa loja seria de $20 \%$. Entretanto, essa solução, que aparentemente não tem nada de errado, não está correta do ponto de vista financeiro. Considerando que os juros representam o valor cobrado pela dívida assumida, é importante que essa discussão seja feita com os alunos.

Vejamos. Como a segunda opção apresenta um pagamento no ato da compra, o cliente nesse caso deve decidir se pagará $\mathrm{R} \$ 90,00$ pela mercadoria à vista - já considerando o desconto de $10 \%$ - ou se pagará $\mathrm{R} \$ 60,00$, deixando de gastar a diferença de $\mathrm{R} \$ 30,00$ neste momento, o que deve ser interpretado como a criação de uma dívida de $\mathrm{R} \$ 30,00$ com a loja.

Ocorre que após um mês, o valor da dívida de $\mathrm{R} \$ 30,00$, adiado no mês anterior, torna-se $\mathrm{R} \$ 60,00$, revelando uma absurda taxa de $100 \%$ de juros em apenas um mês!

Esse tipo de situação, com certeza, é familiar aos alunos do Ensino Fundamental e poderia ser trabalhado com estudantes do $7^{\circ}$ ou $8^{\circ}$ anos de 
escolaridade, os quais teriam plenas condições, não só de resolver o problema, mas de discuti-lo criticamente com os outros colegas e professor.

Vale ainda comentar que, embora a utilização de juros simples não seja tão usual no cotidiano das pessoas em geral, há algumas situações relacionadas às operações financeiras nas quais ela é utilizada. Por exemplo, são aplicados juros simples nos descontos bancários ou atrasos de pagamentos por períodos menores que a unidade de tempo de cobrança dos juros, por exemplo, pois nessas situações isso se torna mais vantajoso para o banqueiro, uma vez que o montante em juros simples é maior que o montante em juros compostos, conforme demonstrado pelo gráfico na Figura 19.

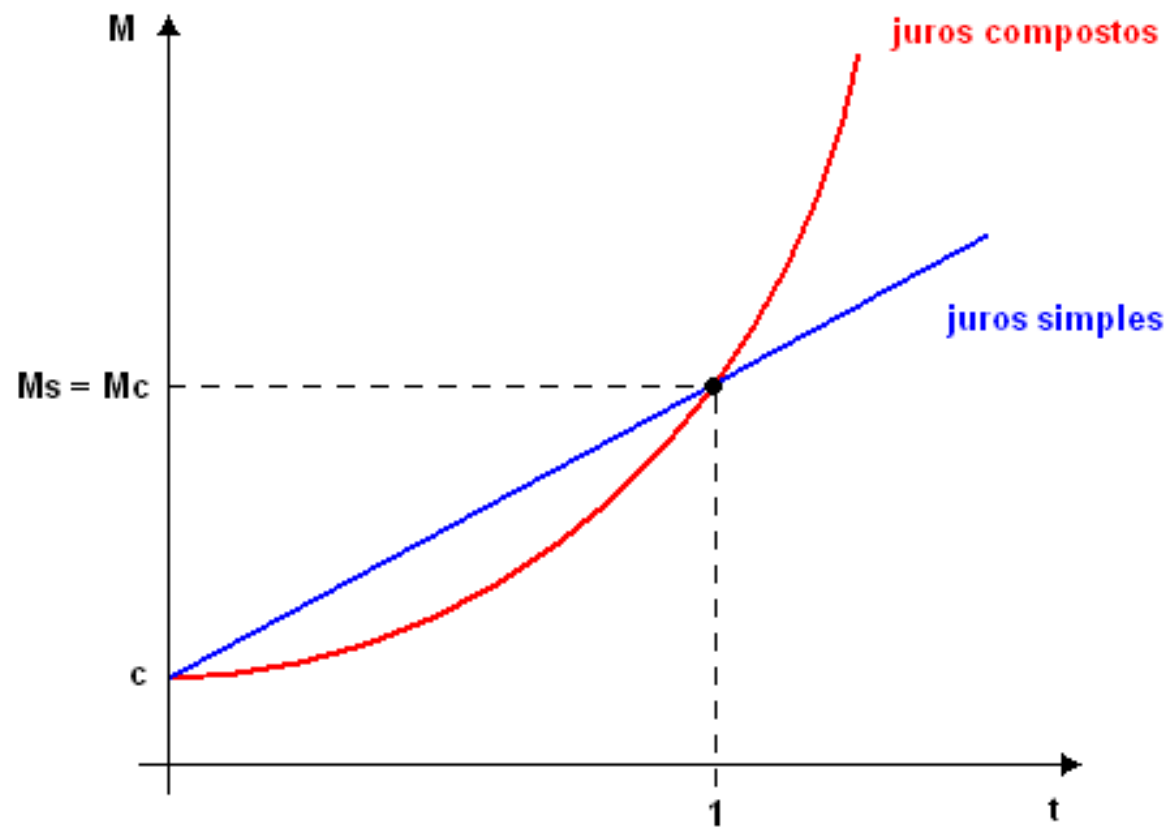

Figura 19 - Gráfico comparativo entre um capital aplicado com juros simples e juros compostos.

Fonte: ARAÚJO, Milton. Pílulas de Matemática Financeira (2). 2013. Disponível em: http://profmilton.blogspot.com.br/2013/12/pilulas-de-matematica-financeira-2.html.

Entretanto, acreditamos que essas considerações poderiam ser feitas apenas como curiosidades para o aluno do $8^{\circ}$ ou $9^{\circ}$ anos do Ensino Fundamental, na faixa de 13-14 anos de idade.

Por ora, bastaria que esse aluno soubesse que, embora os juros compostos tenham larga aplicação em nosso cotidiano, existem situações, demonstradas matematicamente, em que se torna mais vantajoso para o credor a cobrança por 
juros simples. A discussão sobre esse assunto poderia ser mais bem aprofundada e demonstrada para um estudante do Ensino Médio.

A diferença, ao longo do tempo, entre o valor final de uma dívida atualizada pelo regime de juros simples e o correspondente pelo regime de juros compostos também pode ser objeto de análise pelos estudantes. Neste sentido, defendemos a contextualização do estudo por meio do uso de situações reais, conforme trataremos a seguir.

Atualmente, no Brasil, tem sido bastante noticiada a situação da dívida dos Estados com a União. Os Estados brasileiros, extremamente endividados, recorreram à Justiça com pedidos para mudar o regime de aplicação dos juros sobre suas dívidas. Hoje, essa dívida é reajustada através de juros compostos, o que vale para praticamente todo empréstimo obtido no mercado financeiro. O pleito dos Estados é de que os seus saldos devedores com a União sejam reajustados por juros simples. Tal solicitação encontra amparo jurídico em texto de Lei que não deixa explícita qual seria a forma de cobrança dos juros da dívida e o Supremo Tribunal Federal - STF inclusive já proferiu decisão preliminar beneficiando alguns Estados.

Desconsiderando o aspecto jurídico da discussão, os efeitos dela são um assunto que o professor de matemática de Ensino Fundamental poderia debater em sala de aula com seus alunos do $9^{\circ}$ ano de escolaridade, na faixa de 14 anos de idade, ao falar de juros.

Os noticiários que tratam do assunto relatam que os efeitos dessa mudança na cobrança da dívida dos Estados gerariam consequências drásticas para o Governo Federal, pois quanto mais longo o prazo e maior a taxa de juros, maior tende a ser o impacto negativo provocado pela troca do regime de juros compostos para o regime de juros simples. No caso em estudo, a dívida dos Estados tem prazo de 30 anos.

A Tabela 3 apresenta uma tabela elaborada pelo Núcleo de Estudos e Pesquisas da Consultoria Legislativa do Senado Federal com dados de janeiro de 2013, a qual demonstra que, se adotado o regime de juros simples para o recálculo da dívida de todos os Estados, o desconto seria de 313 bilhões, que representam $78 \%$ do saldo devedor total e, ainda, 13 Estados deixariam de ser devedores e passariam a ser credores da União. 
Tabela 3 - Estimativa do desconto da dívida estadual pela aplicação da Selic no critério de juros simples.

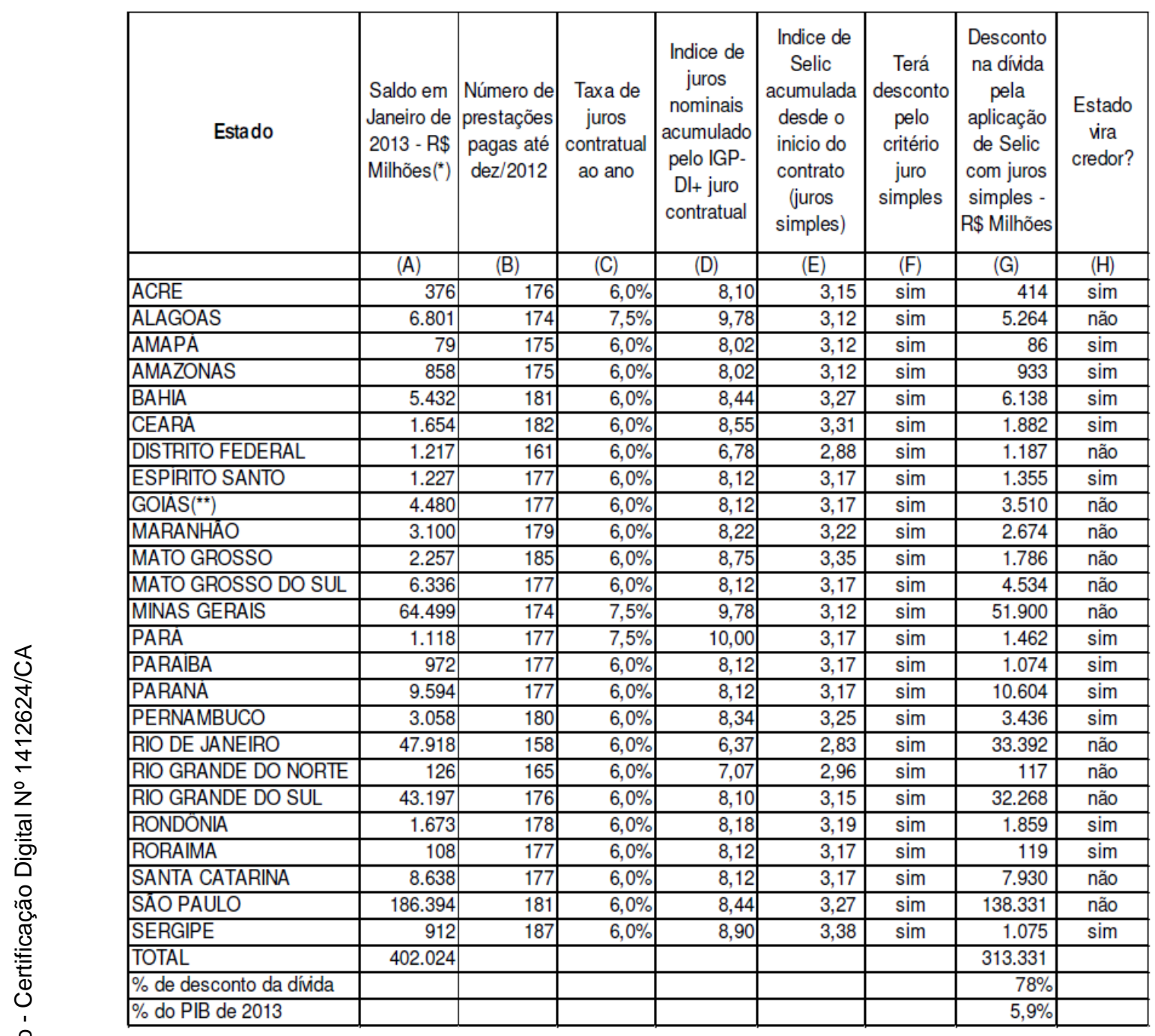

Fonte: MENDES, M. J. O Impacto Fiscal das Propostas de Refinanciamento da Dívida dos Estados. Brasília: Núcleo de Estudos e Pesquisas/CONLEG/Senado, março/2016 (Boletim Legislativo $\mathrm{n}^{0}$ 44, de 2016). Disponível em: <https://www12.senado.leg.br/publicacoes/estudos-legislativos/tipos-de-estudos/boletinslegislativos/bol44/view>. Acesso em 27 maio 2016.

Fazendo alusão a duas perguntas que foram apresentadas pela Pesquisa sobre Educação Financeira Global da S\&P, as quais avaliam o conhecimento de juros compostos do entrevistado e foram exibidas no capítulo 2 (seção 2.2) desta dissertação, somos da opinião que as respostas corretas às perguntas poderiam ser encontradas por um aluno do $7^{\circ}$ ano do Ensino Fundamental, na faixa de 12 anos de idade. A seguir detalharemos nossas considerações acerca das perguntas.

A primeira pergunta sobre juros trata sobre uma quantia em dinheiro depositada em uma conta bancária, por um período de dois anos, a uma taxa de 
$15 \%$ ao ano. Pergunta-se se, no segundo ano, o banco adicionará mais dinheiro à conta que no primeiro ano ou se adicionará a mesma quantia de dinheiro nos dois anos.

Um aluno de Ensino Fundamental, ao qual já foi apresentado o conceito de juros compostos com aplicações, tem todas as condições de perceber que, na questão proposta, os rendimentos do segundo ano serão superiores aos do primeiro ano. A quantia sobre a qual se incidirão os rendimentos do segundo ano, ainda que com a mesma taxa, é maior do que aquela que constava na conta no início do primeiro ano. Logo, o banco adicionará à conta mais dinheiro no segundo ano do que no primeiro.

Importante ressaltar que o objetivo da pergunta proposta na Pesquisa era saber se o entrevistado tinha noção do que aconteceria com o valor dos rendimentos no segundo ano, uma vez que o valor exato a ser depositado não foi solicitado. Bastava que o entrevistado tivesse a convicção de que esse valor seria maior que no primeiro ano para dar uma resposta correta à questão.

É muito apropriado ainda observar que a pergunta proposta sequer menciona o regime de juros. De fato, o que se espera do avaliado é que ele tenha conhecimento suficiente para compreender que o regime a ser aplicado é o de juros compostos, o que é perfeitamente compatível com nossa posição acerca do ensino de juros. Mas não se pode dizer o mesmo em relação ao proposto no livro didático típico, que, conforme já enfatizamos, induz o estudante a pensar em juros simples.

A segunda pergunta sobre juros aborda uma situação em que se tinha $\$ 100$ em uma conta poupança, com rendimentos de $10 \%$ ao ano. É solicitado que o entrevistado informe quanto teria na conta após cinco anos se não fizesse nenhuma retirada.

Pelas opções de resposta apresentadas, percebe-se que o objetivo da questão é justamente verificar se o avaliado percebe o conceito de juros compostos na situação proposta. O entrevistado poderia escolher se possuiria menos que $\$ 150$, exatamente $\$ 150$ ou mais que $\$ 150$ após cinco anos.

Mais uma vez percebe-se que não há pretensão de que o avaliado saiba exatamente quanto ele teria no fim desses cinco anos, bastando que o mesmo soubesse que certamente esse valor seria maior que $\$ 150$. Na verdade, sabemos 
que esse valor será superior a $\$ 160$, mas a comprovação desse fato requereria uma habilidade de cálculo numérico mais complexo por parte do entrevistado.

O conhecimento do conceito de juros compostos comparado ao conceito de juros simples permitiria que um aluno do $7^{\circ}$ ano do Ensino Fundamental identificasse a resposta correta à questão com elevado grau de certeza, ainda que não conseguisse precisar o valor imediatamente. Além do conhecimento sobre o conceito de juros compostos, a questão requer do avaliado a capacidade em fazer estimativas, que já foi objeto de nossas considerações neste trabalho.

Assim, buscamos demonstrar que a abordagem que defendemos nesta dissertação é aquela que capacita o estudante a apresentar as respostas corretas para as perguntas da pesquisa, o que pensamos ser correspondente a contribuir para sua formação na área do letramento financeiro.

Por fim, a partir do estudo sobre juros, o professor de matemática do Ensino Fundamental não pode deixar de debater com seus alunos um tema tão relevante para a realidade brasileira que é a inflação.

\section{5}

\section{Inflação}

Os brasileiros já viveram sérios problemas relacionados à inflação, principalmente na década de 90. Ainda hoje, esse tema nos assombra, já que sabemos quão devastadora ela se torna para o orçamento das famílias e para economia do país.

Segundo o Índice Nacional de Preços ao Consumidor Amplo - IPCA, no ano de 2015 a inflação brasileira foi de 10,67\%. Embora inflação seja um conceito de Economia e o estudo de suas causas e controles resida nessa área, a matemática é fundamental para a sua medição e o entendimento dos seus efeitos.

É importante destacar que a Pesquisa sobre Educação Financeira Global da S\&P mostrou evidências de aprendizado através da experiência, uma vez que os participantes nos países que viveram a hiperinflação sabiam mais sobre inflação, em comparação com aqueles em que a inflação é costumeiramente baixa ou há deflação. 
Entendemos que o professor de matemática do Ensino Fundamental, principalmente no $8^{\circ}$ e $9^{\circ}$ anos de escolaridade, pode (e deve) iniciar o debate desse tema com seus alunos, além de apresentar situações-problema nas quais fiquem evidenciados os efeitos da inflação.

O debate poderia ser iniciado com questionamentos aos alunos sobre o que sabem do assunto. Embora ainda jovens, certamente já ouviram esse termo em casa ou em algum meio jornalístico.

O professor poderia propor uma atividade de pesquisa em que os alunos pudessem entrevistar seus responsáveis ou adultos mais velhos que vivenciaram profissionalmente as décadas de 80 e início dos anos 90, período em que o Brasil vivenciou a hiperinflação e no qual a maioria dos alunos do Ensino Fundamental de hoje não havia sequer nascido.

A partir daí, poderiam ser estimuladas situações-problema sobre o assunto. Vejamos um exemplo no Quadro 10. 
Quadro 10 - Questão envolvendo a ideia de inflação.

Considere que, no mês de maio de 2016, um pacote de biscoitos de determinado tipo custe $\mathrm{R} \$ 5,00$ em um supermercado local e que você receba uma mesada de $\mathrm{R} \$ 30,00$ por mês.

a) Quantos pacotes de biscoito desse tipo conseguiria comprar com sua mesada no supermercado no mês de maio?

b) Se no mês de junho de 2016 o pacote de biscoitos passou a custar $\mathrm{R} \$ 6,00$ e sua mesada continua a mesma, quantos pacotes desse biscoito conseguiria comprar em junho de 2016?

c) Qual foi o percentual de aumento verificado no preço desse biscoito entre maio e junho de 2016 ?

d) Qual foi o percentual de redução na quantidade de pacotes de biscoito desse tipo que você conseguiria comprar com sua mesada entre maio e junho de 2016 ?

e) Qual o percentual de aumento de mesada que você deveria solicitar em junho para conseguir comprar a mesma quantidade de pacotes de biscoito que comprou em maio?

Fonte: Elaborada pela autora.

Sugerimos uma situação-problema que envolve mesada e compra de pacote de biscoitos para aproximar o assunto da realidade do aluno. Uma discussão inicial que envolvesse salário mínimo e cesta básica, por exemplo, poderia ser um fator de dificuldade de entendimento para essa faixa etária do Ensino Fundamental.

As respostas das letras a) e b) seriam obtidas por uma divisão simples de 30 por 5 e 30 por 6 resultando na compra de 6 pacotes no mês de maio e 5 pacotes no mês de junho, o que certamente não traria dificuldade aos alunos.

O objetivo dessas perguntas é fazer com que o aluno perceba o impacto do aumento de preços, quando esse aumento não é refletido no valor da mesada utilizada para compra.

Para a resolução das letras c) e d) o aluno que já estudou porcentagem e juros não teria dificuldade em descobrir que houve um aumento de $20 \%$ ( $\mathrm{R} \$ 1,00$ em $\mathrm{R} \$ 5,00)$ sobre o preço do pacote de biscoitos e uma redução de aproximadamente 17\% (1 pacote de biscoitos em 6 pacotes) na quantidade de 
pacotes de biscoitos que se poderia comprar. Isso é importante para que ele comece a perceber que esses percentuais não são iguais.

A letra e) tem o objetivo de mostrar ao aluno que, quando o aumento de preço é acompanhado pelo mesmo percentual de aumento dos ganhos para a compra, não há impacto algum nos efeitos dessa compra.

A partir da situação descrita e da reflexão sobre a hipótese de um aumento geral dos preços, o professor poderia explicar para os alunos que a inflação é um conceito econômico que representa o aumento de nível de preços, ou seja, é a média do crescimento dos preços de um conjunto de bens e serviços em um determinado período em um país ou região.

Pelo fato de que, em um processo inflacionário, não seria possível comprar a mesma cesta de produtos que adquiríamos até então, sem que dispendêssemos mais dinheiro para tal, dizemos que ocorre a diminuição do poder de compra do dinheiro nesse cenário. Dependendo do nível de desenvolvimento da turma, o professor poderia comentar que esta diminuição, em termos percentuais, é exatamente o que foi apurado na letra d).

O professor pode mencionar ainda que, no Brasil, existem vários índices que medem a inflação, sendo alguns deles o IGP ou Índice Geral de Preços (calculado pela Fundação Getúlio Vargas) e o IPCA ou Índice de Preços ao Consumidor Amplo (medido pelo Instituto Brasileiro de Geografia e Estatística IBGE).

No que diz respeito à pergunta que foi apresentada pela Pesquisa sobre Educação Financeira Global da S\&P, a qual avalia o conhecimento do entrevistado acerca de inflação e foi exibida no capítulo 2 (seção 2.2) desta dissertação, acreditamos que a resposta correta à pergunta poderia ser encontrada por um aluno do $8^{\circ}$ ou $9^{\circ}$ ano do Ensino Fundamental, na faixa de 13-14 anos.

A questão solicita que o entrevistado suponha que o preço daquilo que compra hoje duplique em 10 anos e que sua renda também duplicou nesse período. $\mathrm{O}$ avaliado deve responder se conseguiria comprar mais, menos ou a mesma quantidade do que compra hoje.

A pergunta tem como objetivo avaliar se o entrevistado entende a relação entre a inflação e poder de compra da moeda. Preferiu-se informar que os preços duplicaram, em vez de mencionar um aumento de $100 \%$ nos preços. Somos de 
opinião que isso foi feito para que a avaliação residisse exclusivamente sobre o tema inflação, evitando que o entrevistado errasse ou não respondesse à questão por lacunas de conhecimento no que se refere a um aumento em percentual.

Um aluno do $8^{\circ}$ ou $9^{\circ}$ ano do Ensino Fundamental ao qual tivessem sido apresentadas situações-problema envolvendo o tema inflação poderia responder seguramente que seria possível comprar a mesma quantidade que se compra hoje na situação apresentada.

Note-se ainda que a pergunta da pesquisa, mais uma vez, privilegia o conhecimento sobre o assunto e a capacidade de raciocínio, sem a necessidade de execução de cálculos escritos ou aplicação de fórmulas para que a resposta certa fosse encontrada.

\section{6}

\section{Diversificação do risco}

Quando nos deparamos com a pergunta sobre diversificação do risco proposta pela Pesquisa sobre Educação Financeira Global da S\&P, percebemos aí um verdadeiro desafio para a abordagem do tema com alunos do Ensino Fundamental.

O entendimento de tal conceito, que não é tão simples como pode parecer, apresenta como pré-requisito o conhecimento de Valor Esperado - ou esperança matemática - que, segundo Silva Filho (2016) não costuma ser um conteúdo ensinado, nem para alunos de Ensino Médio.

Considerando que a Pesquisa Global considerou adultos os indivíduos com 15 anos ou mais e considerando, ainda, que no Brasil os jovens concluem o Ensino Fundamental na faixa de 15 anos, nos perguntamos se os alunos desse segmento seriam capazes de responder corretamente, com grau de convicção, a pergunta que foi exibida no capítulo 2 (seção 2.2) desta dissertação e indagava sobre ser mais seguro aplicar todo o dinheiro em um negócio ou investimento ou aplicar o dinheiro em vários negócios ou investimentos.

Balizada em nossa convicção acerca de que a aprendizagem se torna bem mais significativa quando alicerçada em situações mais próximas de nossa realidade, resolvemos aplicar um questionário (Anexo A) a um grupo de 30 
alunos, com idades entre 13 e 15 anos, do $8^{\circ}$ ano do Ensino Fundamental da rede pública do município de Duque de Caxias, com o objetivo de perceber seu comportamento em situações que envolvam a possibilidade de diversificação do risco.

As questões integrantes do questionário foram concebidas de modo a estarem próximas de realidade do aluno. Assim, foram criadas situações de diversificação do risco usando provas e questões, em lugar de negócios ou investimentos.

A primeira questão indagou sobre a preferência do aluno quanto a realizar uma única prova no bimestre para determinação de seu conceito ou realizar três provas para calcular a sua média do bimestre.

Nesse caso obtivemos o seguinte resultado, demonstrado no gráfico da Figura 20:

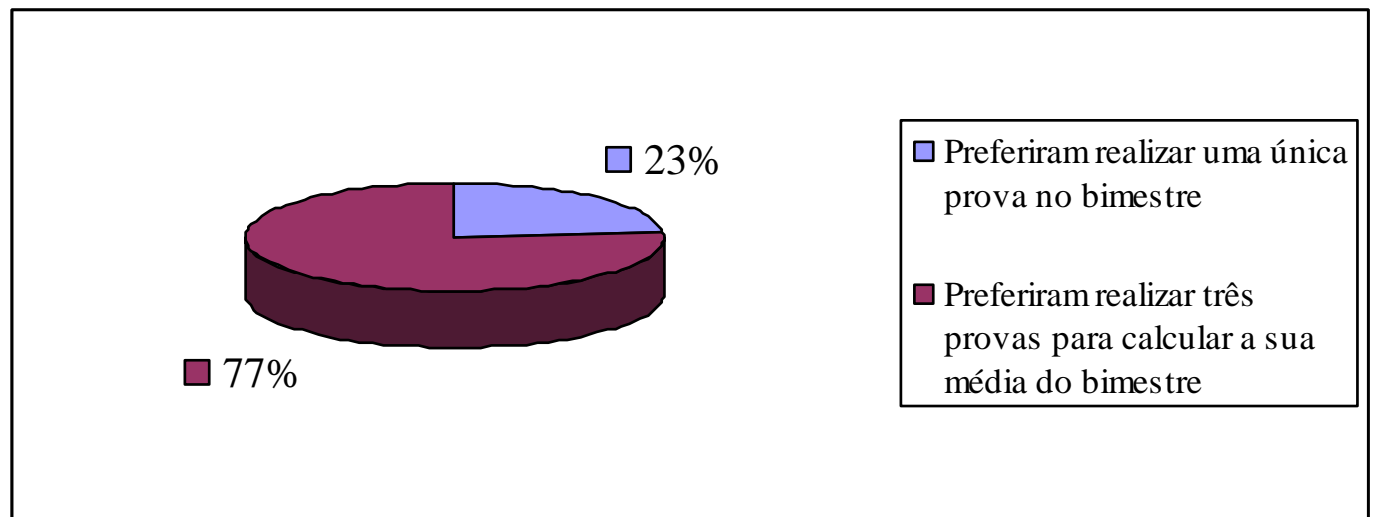

Figura 20 - Gráfico representativo da preferência dos alunos em realizar uma única prova bimestral ou três provas bimestrais para se efetuar a média.

Fonte: Questionário de Diversificação do Risco - Anexo A, com percentual aproximado.

A segunda questão abordou a preferência do aluno quanto a realizar uma prova com uma única questão valendo 10 pontos ou cinco questões, com cada qual valendo dois pontos.

Os resultados encontram-se demonstrados no gráfico da Figura 21: 


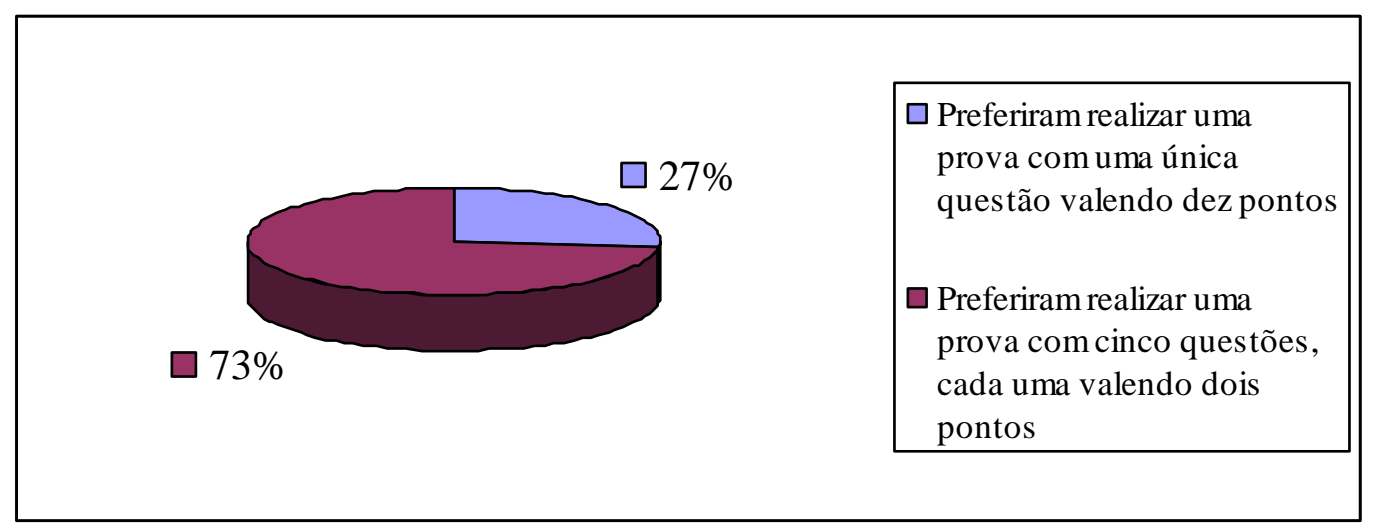

Figura 21 - Gráfico representativo da preferência dos alunos em realizar uma prova com uma única questão que vale 10 pontos ou cinco questões, com cada qual valendo 2 pontos.

Fonte: Questionário de Diversificação do Risco - Anexo A, com percentual aproximado.

É interessante observarmos que, ainda que o aluno nessa faixa etária e segmento de ensino não tenha a maturidade e o conteúdo necessários ao entendimento dos conceitos que envolvem o tema, a intuição da maioria deles os leva a optar pela diversificação de risco em situações em que essa decisão se exija.

O ditado popular, bastante conhecido, de que não se deve colocar todos os ovos em uma cesta só, devido ao risco de todos se quebrarem, pode ser aplicado tanto em situações mais simples de nosso cotidiano, quanto em situações mais complexas que envolvam investimentos ou negócios.

Nossa sugestão é que essas situações cotidianas, que envolvam decisões acerca da diversificação do risco, sejam trabalhadas com os alunos no Ensino Fundamental pelo professor de matemática. Isso, certamente, fortalecerá a base do raciocínio futuro dos educandos em situações mais complexas nesse sentido. 


\title{
Conclusão
}

\author{
Sonho que se sonha só \\ É só um sonho que se sonha só \\ Mas sonho que se sonha junto é realidade...
}

Raul Seixas

Esperamos que nosso trabalho possa sensibilizar os professores de matemática quanto à urgência do debate sobre a falta de letramento financeiro da população e quais seriam as estratégias que nós, educadores, poderíamos adotar para modificar esse quadro.

Não é nossa pretensão esgotar o tema em nosso trabalho, pois sempre haverá boas contribuições entre professores, como nós, dedicados à melhoria do ensino de matemática financeira dos educandos do Ensino Fundamental.

O presente trabalho pretende servir de base para reflexão, apoiada na nossa experiência, dos professores de matemática que atuam nas turmas de Ensino Fundamental e encontram dificuldades em trabalhar Matemática Financeira com seus alunos, considerando a ausência deste assunto nos livros didáticos frequentemente adotados pelas escolas nessa modalidade.

Almejamos ter colaborado com motivações e ideias para que os professores conscientes e atuantes no Ensino Fundamental possam recriar ou buscar novas propostas, igualmente fundamentadas, para o ensino de Matemática Financeira, sob uma perspectiva contextualizada.

Ambicionamos também contribuir para nosso objetivo maior, que é a formação dos alunos como cidadãos conscientes, críticos e autônomos em relação ao uso do dinheiro, os quais busquem seu equilíbrio financeiro e qualidade de vida na tomada de decisões financeiras.

O estudo demonstrou que, embora árdua, a tarefa de abordar conceitos de letramento financeiro no Ensino Fundamental, sob a plataforma da Matemática Financeira Básica, é perfeitamente possível, adequando a linguagem e a profundidade ao ano de escolaridade dos estudantes.

Sugerimos como temas para trabalhos futuros: 
- a discussão acerca de propostas pedagógicas e metodológicas para o ensino de Matemática Financeira para turmas do primeiro segmento do Ensino Fundamental ( $1^{\circ}$ ao $5^{\circ}$ ano de escolaridade), considerando a premissa de que esse debate deve iniciar tão cedo quanto possível;

- reflexões sobre a abordagem metodológica de tópicos de Matemática Financeira para turmas de Jovens e Adultos, haja vista que esse público já está inserido no cenário econômico nacional como força produtiva e consumidora;

- propostas de trabalhos, para o Ensino Médio, que possam relacionar o conceito de diversificação do risco ao estudo de valor esperado (esperança), considerando que o conceito costuma ser apenas tangenciado na Educação Básica e é significativo para tomada de decisões que envolvam investimentos, por exemplo; e

- análise dos aspectos matemáticos do material da ENEF sobre educação financeira para o Ensino Fundamental, mencionado no capítulo 3 (seção 3.3.2) e disponibilizado em meio virtual do $1^{\circ}$ ao $9^{\circ}$ de escolaridade, abordando a efetividade do material para o ensino de Matemática Financeira nesses segmentos.

Por fim, colocamo-nos à disposição para troca de experiências e sugestões no endereço eletrônico fnsouzag@gmail.com. 


\section{Referências Bibliográficas}

ARAÚJO, M. Pílulas de Matemática Financeira (2). 2013. Disponível em: $<$ http://profmilton.blogspot.com.br/2013/12/pilulas-de-matematica-financeira2.html>

ASSOCIAÇÃO DE EDUCAÇÃO FINANCEIRA DO BRASIL - AEF-Brasil. Educação financeira de adultos. 2016a. Disponível em: $<$ http://www.aefbrasil.org.br/index.php/programas-e-projetos/programa-deeducacao-financeira-de-adultos $>$. Acesso em: 30 abr. 2016.

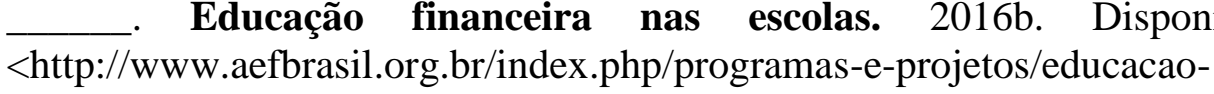
financeira-nas-escolas>. Acesso em: 30 abr. 2016.

Educação financeira no ensino médio. 2016c. Disponível em: $<$ http://www.aefbrasil.org.br/index.php/programas-e-projetos/educacaofinanceira-nas-escolas/educacao-financeira-no-ensino-medio>. Acesso em: 04 maio 2016.

Educação financeira no ensino fundamental. 2016d. Disponível em: <http://www.aefbrasil.org.br/index.php/programas-e-projetos/educacaofinanceira-nas-escolas/educacao-financeira-no-ensino-fundamental $>$. Acesso em: 04 maio 2016.

BANCO CENTRAL DO BRASIL. Brasil: implementando a Estratégia Nacional de Educação Financeira. 2016. Disponível em: <http://www.bcb.gov.br/pre/pef/port/Estrategia_Nacional_Educacao_Financeira_ ENEF.pdf>. Acesso em: 30 abr. 2016.

BRASIL. Base Nacional Curricular Comum: linha do tempo. 2016h. Disponível em: <http://basenacionalcomum.mec.gov.br/\#/site/linha-do-tempo>. Acesso em: 30 abr. 2016.

Constituição da República Federativa do Brasil. 1988. Disponível em: <http://www.planalto.gov.br/ccivil_03/Constituicao/Constituicao.htm>. Acesso em: 22 abr. 2016.

Decreto $n^{\circ}$ 7397, de 22 de dezembro de 2010. Institui a Estratégia Nacional de Educação Financeira - ENEF, dispõe sobre a sua gestão e dá outras providências. 2010a. Disponível em: <http://www.planalto.gov.br/ccivil_03/_Ato20072010/2010/Decreto/D7397.htm>. Acesso em: 30 abr. 2016. 
Decreto $\mathrm{n}^{\mathbf{0}} 8584$, de 07 de dezembro de 2015. Altera o Decreto $\mathbf{n}^{\mathbf{0}} \mathbf{7 . 3 9 7}$, de 22 de dezembro de 2010, que institui a Estratégia Nacional de Educação Financeira - ENEF e dispõe sobre sua gestão. 2015. Disponível em: <http://www.planalto.gov.br/ccivil_03/_Ato2015-

2018/2015/Decreto/D8584.htm>. Acesso em: 30 abr. 2016.

Estratégia Nacional de Educação Financeira: legislação. 2016 b. Disponível em: <http://www.vidaedinheiro.gov.br/enef-legislacao.html>. Acesso em: 30 abr. 2016.

Estratégia Nacional de Educação Financeira: Mapeamento Nacional. 2016e. Disponível em: <http://www.vidaedinheiro.gov.br/pagina-24mapeamento_nacional.html>. Acesso em: 30 abr. 2016.

Estratégia Nacional de Educação Financeira: no mundo. 2016a. Disponível em: <http://www.vidaedinheiro.gov.br/pagina-28-no_mundo.html>. Acesso em: 30 abr. 2016.

Estratégia Nacional de Educação Financeira: Plano Diretor da ENEF. Anexos. 2016f. Disponível em: <http://www.vidaedinheiro.gov.br/docs/PlanoDiretorENEF1.pdf >. Acesso em: 30 abr. 2016.

. Estratégia Nacional de Educação financeira: programas transversais. 2016d. Disponível em: <http://www.vidaedinheiro.gov.br/pagina-39programas_transversais.html>. Acesso em: 30 abr. 2016.

Estratégia Nacional de Educação Financeira: quem somos e o que fazemos. 2016c. Disponível em: <http://www.vidaedinheiro.gov.br/pagina-29quem_somos_e_o_que_fazemos.html>. Acesso em: 30 abr. 2016.

. Lei $\mathrm{n}^{\circ}$ 9394, de 20 de dezembro de 1996. Estabelece as diretrizes e bases da educação nacional. 1996. Disponível em <http://www.planalto.gov.br/ccivil_03/leis/L9394.htm>. Acesso em: 22 abr. 2016.

Lei $n^{\circ} 13.005$, de 25 de junho de 2014. Aprova o Plano Nacional de Educação - PNE e dá outras providências. Disponível em <http://www.planalto.gov.br/ccivil_03/_ato2011-2014/2014/lei/113005.htm>. Acesso em: 22 abr. 2016.

2013. Mapeamento Nacional das Iniciativas de Educação Financeira $\left(1^{\circ}\right)$. Disponível

em: <http://www.vidaedinheiro.gov.br/docs/RelatorioEstatisticoENEF.pdf $>$. Acesso em: 22 abr. 2016.

Ministério da Educação: consulta pública sobre Base Nacional Comum recebeu mais de 12 milhões de contribuições. 2016g. Disponível em: <http://portal.mec.gov.br/ultimas-noticias/211-218175739/34971-consultapublica-sobre-base-nacional-comum-recebeu-mais-de-12-milhoes-decontribuicoes>. Acesso em: 30 abr. 2016. 
Ministério da Educação. Secretaria de Educação Fundamental. Parâmetros Curriculares Nacionais: Matemática $\left(1^{\circ}\right.$ e $2^{\circ}$ ciclos do ensino fundamental). v. 3. Brasília: MEC, 1997. Disponível em: <http://portal.mec.gov.br/seb/arquivos/pdf/livro03.pdf>. Acesso em: 15 maio 2016.

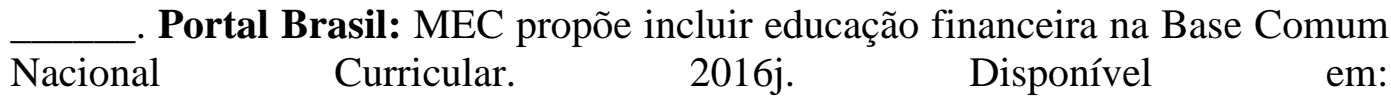
<http://www.brasil.gov.br/educacao/2016/02/mec-propoe-incluir-educacaofinanceira-na-base-comum-nacional-curricular>. Acesso em: 30 abr. 2016.

. Programa de Educação Financeira nas Escolas: Modelo Conceitual e Objetivos. 2016i. Disponível em: <http://www.edufinanceiranaescola.gov.br/modelo-conceitual-e-objetivos>. Acesso em: 30 abr. 2016.

Programa de Educação Financeira nas Escolas: Materiais. 2016k. Disponível em: <http://www.edufinanceiranaescola.gov.br/ensino-fundamental>. Acesso em: 30 abr. 2016.

\begin{abstract}
BROWN, A. et al. State Mandated Financial Education and the Credit Behavior of Young Adults. 2014. Disponível em: <https://www.federalreserve.gov/pubs/feds/2014/201468/201468pap.pdf>. Acesso em: 04 maio 2016.
\end{abstract}

CARRAHER, T.N. et al. Na vida dez, na escola zero. São Paulo: Cortez, 1988.

D'AMBROSIO, U. Que matemática deve ser aprendida nas escolas hoje? Teleconferência no Programa PEC - Formação Universitária, patrocinado pela Secretaria de Educação do Estado de São Paulo, 27 de julho de 2002. Disponível em: 〈https://sites.google.com/site/etnomath/5>. Acesso em: 14 maio 2016.

2012.

. Educação matemática: da teoria à prática. 23. ed. Campinas: Papirus,

FREIRE, P. Pedagogia da autonomia: saberes necessários à prática educativa. 45. ed. Rio de Janeiro: Paz e Terra, 2013.

KLAPPER, L.; LUSARDI, A.; OUDHEUSDEN, P.v. Financial literacy around the world: insights from the Standard \& Poor's Ratings Services global financial. 2015. Disponível em: 〈http://www.nber.org/papers/w13750.pdf>. Acesso em: 30 abr. 2016.

LUSARDI, A.; MITCHELL, O.S. Planning and financial literacy: how do women fare?. In: Economic Review 98 (2): 413-17. 2008. Disponível em: <http://www.nber.org/papers/w13750.pdf>. Acesso em: 30 abr. 2016.

Financial literacy and planning: implications for retirement well-being. In: Financial Literacy: Implications for Retirement Security and the Financial Marketplace, edited by Olivia S. Mitchell and Annamaria Lusardi, 17-39. 2011 a. 
Oxford and New York: Oxford University Press. Disponível em: <http://www.nber.org/papers/w17078.pdf>. Acesso em: 30 abr. 2016.

Financial literacy around the world: an overview. In: Journal of Pension Economics and Finance 10 (4):497-508. 2011b. Disponível em: <http://www.nber.org/papers/w17107.pdf>. Acesso em: 30 abr. 2016.

The economic importance of financial literacy: theory and evidence. In: Journal of Economic Literature 2014, 52(1), 5-44. 2014. Disponível em: <http://www.nber.org/papers/w18952.pdf>. Acesso em: 30 abr. 2016.

The outlook for financial literacy. In: Financial Literacy: Implications for Retirement Security and the Financial Marketplace, edited by Olivia S. Mitchell and Annamaria Lusardi, 1-15. Oxford and New York: Oxford University Press. 2011c. Disponível em: 〈http://www.nber.org/papers/w17077.pdf〉. Acesso em: 30 abr. 2016.

How ordinary consumers make complex economic decisions: financial literacy and retirement readiness. National Bureau of Economic Research Working Paper 15350. 2009. Disponível em: <http://www.nber.org/papers/w15350.pdf>. Acesso em: 30 abr. 2016.

LUSARDI, A.; MITCHELL, O.S.; CURTO, V. Financial literacy among the young: evidence and implications for consumer policy. In: Journal of Consumer Affairs 44 (2): 358-80. 2010. Disponível em: <http://www.nber.org/papers/w15350.pdf>. Acesso em: 30 abr. 2016.

LUSARDI, A. Financial literacy: a global perspective. In: SEMINÁRIO DE EDUCAÇÃO FINANCEIRA PARA CRIANÇAS E JOVENS, 1., 2015, Rio de Janeiro. Anais eletrônicos... Disponível em: $<$ http://www.portaldoinvestidor.gov.br/portaldoinvestidor/export/sites/portaldoinv estidor/publicacao/Apresentacoes/Seminario/AnnamariaLusardi_presentation_Se m2015.pdf>. Acesso em: 01 maio 2016.

MENDES, M.J. O Impacto Fiscal das Propostas de Refinanciamento da Dívida dos Estados. Brasília: Núcleo de Estudos e Pesquisas/CONLEG/Senado, março/2016 (Boletim Legislativo $\mathrm{n}^{\mathrm{o}} 44$, de 2016). Disponível em: $<$ https://www12.senado.leg.br/publicacoes/estudos-legislativos/tipos-deestudos/boletins-legislativos/bol44/view>. Acesso em 27 maio 2016.

MORGADO, A.C. Matemática Financeira. Rio de Janeiro: IMPA. Programa de Aperfeiçoamento para professores de Matemática do Ensino Médio. 2010. Videoaula disponível em: < http://video.impa.br/index.php?page=janeiro-de2010-2>

MOYSES, L. Aplicações de Vigotsky à educação matemática. 11. ed. Campinas: Papirus, 2012.

NOGUEIRA, F.A. de A. Ensaio sobre o ensino da matemática financeira no Brasil. 81f. Dissertação (Mestrado) - Instituto de Matemática Pura e Aplicada, 2016.

Disponível em: $<$ http://www.profmat- 
sbm.org.br/dissertacoes?polo=\&titulo=\&aluno=FABIANO $\% 20$ ALBERTON $\% 20$ DE\%20ALENCAR\%20NOGUEIRA>. Acesso em: 4 maio 2016.

OECD. Recommendation on principles and good practices for financial education and awareness. Directorate for Financial and Enterprise Affairs. 2005. Disponível em: <http://www.oecd.org/finance/financialeducation/35108560.pdf>. Acesso em: 01 maio 2016.

Life expectancy. In: OECD Factbook 2013: Economic, Environmental and Social Statistics, OECD Publishing, Paris. 2013. Disponível em: $<$ http://www.oecd-

ilibrary.org/docserver/download/3012021ec095.pdf?expires=1462062745\&id=id $\&$ accname $=$ guest $\&$ checksum $=5$ AB7F961FF3048FF4C26CF8D9CAAB782>. Acesso em: 30 abr. 2016.

SÁ, I.P. de. Matemática financeira para educadores críticos. 1. ed. Rio de Janeiro: Ciência Moderna, 2011

SILVA FILHO, H.C. Probabilidade e valor esperado discussão de problemas para o ensino médio. 73f. Dissertação (Mestrado) - Pontifícia Universidade Católica do Rio de Janeiro, 2016. Disponível em: <http://www.profmatsbm.org.br/dissertacoes?polo $=\&$ titulo $=\&$ aluno $=$ haroldo + costa + silva + filho $>$.

Acesso em: 4 jun. 2016.

SILVEIRA, Ê.; MARQUES, C. Matemática: compreensão e prática. 2. ed. São Paulo: Moderna, 2013.

TAYLOR, S.M.; WAGLAND, S. The solution to the financial literacy problem: what is the answer? In: Australasian Accounting, Business and Finance Journal, 7(3), 69-90. 2013. Disponível em: $<$ http://ro.uow.edu.au/cgi/viewcontent.cgi?article $=1451 \&$ context=aabfj $>$. Acesso em: 01 maio 2016.

TENNYSON, S.; NGUYEN, C. (2001). State curriculum mandates and student knowledge of personal finance. In: Journal of Consumer Affairs 35 (2): 241-262. 2010. Disponível em: <http://takechargetoday.arizona.edu/system/files/tennyson01\%20finance.pdf >. Acesso em: 04 maio 2016.

WALSTAD, W.B.; REBECK, K.; MACDONALD, R.A. The effects of financial education on the financial knowledge of high school students. Journal of Consumer Affairs 44 (2): 336-357. 2010. Disponível em: <http://onlinelibrary.wiley.com/doi/10.1111/j.1745-6606.2010.01172.x/epdf>. Acesso em: 04 maio 2016. 


\section{Anexos}

\section{1}

\section{Anexo A - Questionário de diversificação do risco}

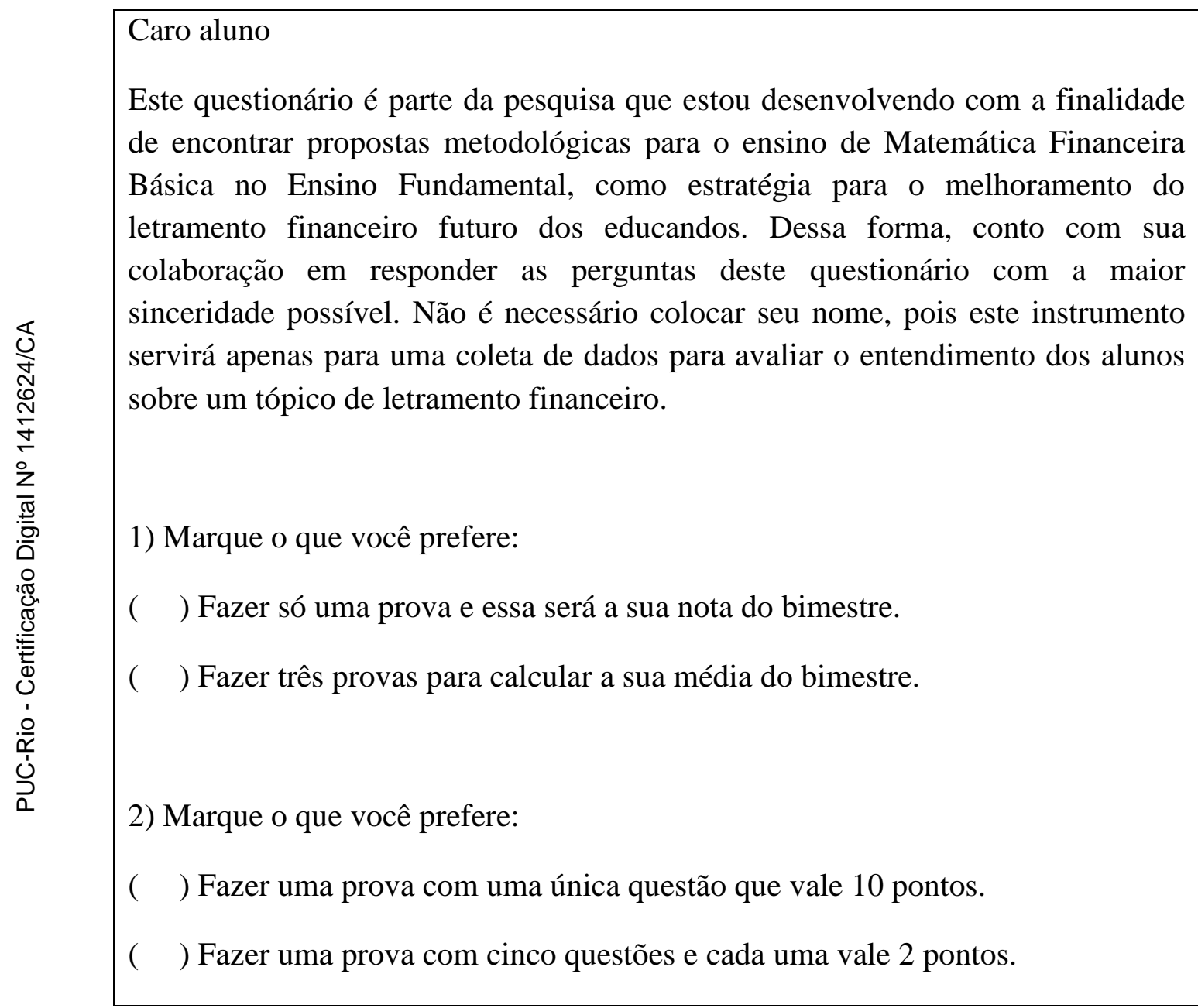

